\title{
Plant galls recorded from Guanacaste Conservation Area-Costa Rica as an integrated concept of a biological database
}

\author{
Omar Gätjens-Boniche ${ }^{l+\oplus}$, Marylin Sánchez-Valverde ${ }^{2}$,Carla Trejos-Araya ${ }^{1}$, Roberto Espinoza-Obando ${ }^{3}$, \\ Adrián A. Pinto-Tomás ${ }^{(1)}$ \& Paul E. Hanson \\ ${ }^{1}$ Instituto Tecnológico de Costa Rica, Campus Tecnológico Local San Carlos, Escuela de Ciencias Naturales y \\ Exactas, Laboratorio de Biología Molecular, Santa Clara, 223-21001 San Carlos, Alajuela, Costa Rica. \\ ${ }^{2}$ Corporación Bananera Nacional (CORBANA, S.A.), Centro de Investigaciones, Eje Fitoprotección; 32-7210, \\ Pococí, Limón, Costa Rica. \\ ${ }^{3}$ Sistema Nacional de Areas de Conservación (SINAC), Área de Conservación Guanacaste, Parque Nacional \\ Santa Rosa, Guanacaste, Costa Rica. \\ ${ }^{4}$ Universidad de Costa Rica, Centro de Investigación en Estructuras Microscópicas y Departamento de \\ Bioquímica, Escuela de Medicina, San José 10102, Costa Rica. \\ ${ }^{5}$ Universidad de Costa Rica, Escuela de Biología; San Pedro, 11501-2060, San José, Costa Rica. \\ *Corresponding author:ogatjens@itcr.ac.cr
}

GÄTJENS-BONICHE O., SÁNCHEZ-VALVERDE, M., TREJOS-ARAYA, C., ESPINOZA-OBANDO, R., PINTOTOMÁS, A.A., HANSON, P.E. Plant galls recorded from Guanacaste Conservation Area-Costa Rica as an integrated concept of a biological database. Biota Neotropica 21(3): e20201153. https://doi.org/10.1590/1676-0611-BN-2020-1153

\begin{abstract}
Galling insects are specialist herbivorous that have the ability of manipulating plant tissue to form complex biological structures called galls. Even though different organisms have the ability to induce galls in plants, insect galls have the highest degree of structural complexity. The main goal of this study was to obtain a preliminary systematic record of plant gall morphotypes from the Guanacaste Conservation Area in Costa Rica and integrate the information into a biological database. Plant gall morphotypes were recorded, characterized and deposited into a specialized herbarium established as a reference for the inventory. Moreover, organisms associated with gall morphotypes were included in the inventory when it was possible to obtain and identify them. Galls were collected in the rainy season over a period of three years. In total, we recorded forty-four families, seventy genera, and eighty-seven host plant species. One hundred thirty-one morphotypes of plant galls were identified in the Guanacaste Conservation Area. The family with the highest number of gall morphotypes was Fabaceae (8.4\%). Leaves were the organ with the largest number of galls (71\%), followed by stems (17.6\%), and apical buds $(6.9 \%)$. The predominant gall shape was globular $(25.2 \%)$, followed by discoid $(18.3 \%)$. Fifty-nine percent of the galls had a glabrous texture, which was most common on leaves, with $77 \%$. One hundred twenty of our field records (91.6\%) of plant galls were new morphotypes not only for Costa Rica but also the world. As a consequence of this research and considering the prospect of future increases in new gall records (and associated organisms), we proposed having the biological entities resulting from the inventory placed in a cecidiarium. This repository represents a standardized and comprehensive way to manage the data and biological materials associated with the plant galls. We also suggest a nomenclature for standardizing gall morphotype registries and identifications. This work is the first and most detailed inventory of plant galls carried out thus far in the Guanacaste Conservation Area. Keywords: Plant gall, morphotype, tropical dry forest, biological database, cecidiarium.
\end{abstract}

\section{Registro de galhas em plantas da Área de Conservação Guanacaste, Costa Rica, como conceito integrado de um banco de dados biológico}

Resumo: Os insetos galhadores são herbívoros especializados, que têm a habilidade de manipular os tecidos vegetais, formando uma complexa estrutura biológica. Diferentes organismos têm a capacidade de induzir galhas, porém as de insetos têm maior grau de complexidade estrutural. O principal objetivo desse estudo foi realizar um levantamento sistemático preliminar das galhas de insetos na Área de Conservação Guanacaste, na Costa Rica, e inserir as informações em uma base de dados biológicos. Os morfotipos de galhas foram registrados, caraterizados e 
Gätjens-Boniche O. et al.

depositados em um herbário estabelecido como base de referência deste inventário. Além disso, quando foi possível obter e identificar os organismos associados a cada morfotipo de galha, eles foram incluídos no inventário. As amostras de galhas foram coletadas na estação chuvosa, durante três anos. No total, foram registradas 44 famílias, 70 gêneros e 87 espécies de plantas hospedeiras. Cento e trinta e um morfotipos de galhas foram identificados na Área de Conservação de Guanacaste. A família com o maior número de morfotipos de galhas foi Fabaceae (8.4\%). Os órgãos vegetais com o maior número de galhas foram as folhas $(71,0 \%)$, seguidas dos caules $(17,6 \%)$, e das gemas apicais com $6,9 \%$. A forma predominante das galhas foi globoide $(25,2 \%)$, seguida da lenticular $(18,3 \%)$ e $59 \%$ das galhas apresentaram textura glabra, observada mais frequentemente folhas (77\%). Cento e vinte morfotipos de galhas (91.6\%) representaram novos registros não só na Costa Rica como também no mundo. Como consequência desta pesquisa e considerando as perspectivas de aumentos futuros de novos registros de galhas (e organismos associados), nós propomos que as entidades biológicas resultantes deste inventário sejam depositadas em um cecidiário. Este repositório representa uma maneira padronizada e abrangente de gerenciar e integrar os dados e os materiais biológicos associados às galhas das plantas. Também sugerimos uma terminologia para padronizar os registros e identificações dos morfotipos de galhas. Este inventário de galhas em plantas é o primeiro e o mais detalhado já realizado na Área de Conservação Guanacaste.

Palavras-chave: morfotipo, floresta seca tropical, banco de dados biológicos, cecidiarium.

\section{Introduction}

Plant galls are atypical plant tissue structures induced by the action and activity of a foreign organism. Although several organisms have the ability to induce galls in plants, the most diverse and complex galls are formed by insects (Shorthouse \& Rohfritsch 1992). Gallinducing insects are highly specialized sedentary herbivores, which feed specifically on certain specialized cells that are found within the plant structure whose formation they have induced (Shorthouse \& Rohfritsch 1992, Tooker et al. 2008, Raman 2011).

Gall-inducing insects generally have specific host plants (CuevasReyes et al. 2014). Gall biology is closely associated with the respective inducing insect, in such a way that galls induced by a particular insect species are basically always the same shape and can differ distinctly from others induced by related species. On the other hand, there are some gall morphotypes induced by different species of insects that present similar shapes (Raman 2011). Distinctive characteristics of each type of gall are probably due to slight variations in the way that each insect species stimulates the development of the gall in the corresponding plant tissue (Shorthouse \& Rohfritsch 1992). Li et al. (2017) suggested that gall development is influenced by the gall-inducing insects as well as by the tissue developmental stage and plant genotypes.

The use of gall morphotypes is a commonly used and reliable parameter because evidence indicates that each gall is unique to a particular gall-inducing insect (Stone and Schönrogge 2003), and each galling species is specific to a particular host plant (Abrahamson et al. 1998). According to Isaias et al. (2013), a gall morphotype could be defined as a characteristic phenotypic variation in a neo-formed plant organ, which is produced by the species-specific interaction between the inducing organism and a specific host plant. Due to the fact that each gall inducer is able to alter the morphogenesis in a predetermined organ (Rohfritsch 1992), and because specificity of galler taxa is strongly linked to an appropriate oviposition site in the host plant (Eigenbrode \& Jetter 2002), gall morphotype is widely used as a way to refer to types of plant galls. The vast majority of gall-inducing arthropods are restricted to a single host plant species, thus corroborating the idea that the gall morphotype can be used as reliable substitute of gall-inducing species. In addition, gall polymorphism, which could lead to failures in the identification of galls, appears to be a rather rare phenomenon (Carneiro et al. 2009).

Thousands of gall-inducing insects have been identified around the world, for the most part belonging to the orders Thysanoptera, Hemiptera, Lepidoptera, Coleoptera, Diptera, and Hymenoptera (Rohfritsch \& Shorthouse 1982, Leitch 1994, Williams 1994, Hanson \& Gómez-Laurito 2005, Espírito-Santo \& Fernandes 2007, Ansaloni et al. 2018). Gall-inducing insects induce the formation of galls in leaves, buds, flowers, stems, roots and other organs of the plant, depending on the gall-inducing species. A growing number of studies on the diversity and abundance of plant gall morphotypes, and their respective inducing insects, allowed us to build upon the existing information. With a certain regularity reports are made of records and descriptions of new species of gall-inducing insects (Ronquist \& Liljeblad 2001, Dalbem \& Mendonça 2006, Güçlü et al. 2008, Coelho et al. 2009, Maia \& Oliveira 2010, Maia et al. 2010a, Maia et al. 2010b, Medianero et al. 2010, Sano et al. 2011, Santos et al. 2011a, Maia 2014, De Araújo 2017, Bergamini et al. 2017, Coelho et al., 2017, Martins et al. 2018, Ley-López et al. 2019).

Inventories of biological specimens are an important tool to know and preserve biological diversity. To date, for tropical regions, detailed inventories on the occurrence and diversity of gall morphotypes are scarce and incomplete. In the Neotropical Region, the majority of plant gall morphotype records are from Brazil (Urso-Guimarães \& Scarelli-Santos 2006, Saito \& Urso-Guimarães 2012, Isaias et al. 2013, Carvalho-Fernandes et al. 2016, Urso-Guimarães et al. 2017, Araújo 2017, Liu et al. 2018, Flor et al. 2018, Ascendino \& Maia 2018, Vieira et al. 2018, Silva et al. 2018, Araújo et al. 2019, Ribeiro et al. 2019, among others) and some of them were conducted in different types of tropical dry forests or semi-arid ecosystems (Coelho et al. 2009, Santos et al. 2011b, Maia \& Souza 2013, Costa \& Araújo 2019). Likewise, other reports have been done for the Mexican dry forest (Cuevas-Reyes et al. 2004, Cuevas-Reyes et al. 2014). For the Costa Rican flora there are no systematic and detailed records of plant galls for specific regions or ecosystems. Studies are restricted to sporadic or general reports (Gómez \& Kisimova-Horovitz 1997, Hanson \& Gómez-Laurito 2005, Retana-Salazar \& Nishida 2007, Retana-Salazar \& Sánchez-Chacón 2009, Hanson et al. 2014). Hanson et al. (2014) reported 1,100 morphospecies of gall-inducers, distributed in six orders of insects, 
from Costa Rica. Nevertheless, this survey was restricted to the identification of the insect gall inducers and their associated parasitoids, using plant gall morphotypes as indirect indicators of insect morphospecies, and therefore lacking detailed descriptions of the gall morphotypes found, usually without associated images. The work carried out by Ley-López et al. (2019) in the area of Sarapiquí, in northern Costa Rica provides primarily a checklist of the native vascular plants found to harbor galls.

The Guanacaste Conservation Area (Área de Conservación Guanacaste, ACG for its acronym in Spanish) is located in the northwest region of Costa Rica, in the life zone categorized as tropical dry forest (Holdridge \& Tosi 1967). ACG is a conglomeration of several national parks and other natural areas (sectors), among which are Santa Rosa National Park, Guanacaste National Park, Rincón de la Vieja National Park, Murciélago Sector, among others (SINAC 2014). ACG protects the most emblematic tropical dry forest in Central America (QuirósArias 2017). This Costa Rican national park was created to favor the restoration process of old pasture areas into the primary and secondary forest through natural succession. Since 1999 it it has been proclaimed a World Heritage Site by UNESCO (Quirós-Arias 2017).

The present work is a first attempt to establish a detailed record and inventory of plant gall morphotypes and their associated organisms in the Guanacaste Conservation Area utilizing an integrated approach consisting of a biological database with a specialized herbarium (cecidiarium).

\section{Materials and Methods}

\section{Study area}

Fieldwork and sample collection were carried out predominantly in the Pacific area of Guanacaste Conservation Area (Área de Conservación Guanacaste, ACG), Guanacaste province, Costa Rica, located in the northwest region of the country $(10.839366,-85.618176$, administrative area) (Figure 1A). Plants and gall morphotypes were collected in different ecosystems in ACG. The Guanacaste Conservation Area is characterized by having a long dry season, generally from late November to mid-May, with a rainy season from mid-May to November (Borchert 1994, Lobo-Segura 2019). The sampled sites are located in the tropical dry forest ecosystem, as well as areas in the premontane wet transition, according to the Holdridge \& Tosi (1967) classification. In the last decades, ACG has been affected by long periods of drought, being one of the areas most affected by the El Niño phenomenon and climate change projections (Quirós-Arias 2017).

The Guanacaste Conservation Area includes 296,526 acres on land and 106,255 acres of marine habitats. Approximately $65 \%$ of all Costa Rican species are present in this area, representing $2.6 \%$ of the world's biodiversity (SINAC 2014).

\section{Field and laboratory work for gall morphotypes inventory and sampling associated insects}

Galls were sampled by randomly walking the trails and examining the vegetation along the pathways by two people searching simultaneously on both sides of the road. All plants and their aerial organs were observed to a maximum height of approximately 3 meters. Each gall and host plants found were collected and then packed in plastic bags for further processing. The photographic record of each gall morphotype, when possible, was made directly in the field. Randomized trials that were perpendicular to existing trails were used occasionally for sampling galls, with distances varying from 50 to 400 meters, but without a pre-established experimental design.

Plant galls were collected and processed from May 2010 to December 2012 in different types of vegetation that comprised the ACG biome. Field sampling was carried out every 3 or 4 months per collection season, for a period of three days each, covering approximately 6-8 hours of field work per day. Sampling was conducted especially during the rainy season, when there is a greater probability of finding leaves on the plants, due to the marked dry season and a predominantly deciduous forest. Gall samples were collected mainly at lower-medium altitudes of 0 to $1100 \mathrm{~m}$ above sea level (m.a.s.l.): Santa Rosa Sector (La Casona area), Murciélago Sector, Santa Elena Sector, Pocosol Sector (Góngora Area, road to Cacao Volcano), and Rincón de la Vieja National Park. Moreover, gall samples and their corresponding host plants were collected mostly from deciduous plant species typical of non-riparian environments as well as near sites with original-natural forest with evergreen species. More typical riparian sites or similar environments followed comparable field zonification criteria of Frankie et al. (1974) and Borchert (1994). Two Bosque Viejo (Old Forest) patches were sampled: close to La Casona (near the administrative area of Santa Rosa National Park) and from the route to Playa Naranjo Sector. The Bosque Viejo patches are considered remnants of the original forest with little human disturbance and is characterized by an abundance of evergreen plant species.

Specimens of each plant harboring galls were prepared for reference as herbarium vouchers to be identified later. Plant gall specimens with floral or fruit parts for host identification were dried when possible, otherwise the insects obtained, and relevant gall samples were preserved in $70 \%$ ethanol. Since gall traits changed in dried samples, especially their morphology and color, a printed photographic registry of each specimen is included in the inventory. All samples were deposited at the cecidiarium (specialized herbarium) established at the facilities of Technological Institute of Costa Rica (Instituto Tecnológico de Costa Rica, Campus Tecnológico Local San Carlos, Escuela de Ciencias Naturales y Exactas). Also, some selected gall samples were preserved in FAA (formalin, acetic acid, alcohol) for later morphological studies. Collected galls were classified according to place of origin, family, genus, and species of the host plant, and according to the basic morphological type. Sampling site description was registered for all samples, but when there were more than two accessions of plant materials in the inventory, only one description of the sampling site for each morphotype was included here. Collected samples were georeferenced by Global Positioning System (GPS). Each gall morphotype location was geo-referenced using the Decimal Degrees (DD) format. A map to show the reference morphotypes collected per site at ACG was made with QGIS version 3.10.5 (QGIS.org 2020) Development Team and using the following layers from Atlas Digital CR 20082014: Conservation Areas (AConservacionSINAC2014; SINAC 1998), Wild Protected Areas (Areassilvestresprotegidas2014crtm05; SINAC 1999), elevation level (Relieve 2008crtm05; CATIE N.D.), Rivers (Rios150000crtm05; Soto-Montoya 2007), and land cover (Cober2005crtm05; Earth Observation System Laboratory et al. 2006). To facilitate visualization of geographical location, some neighboring galls collected from nearby areas (i.e., spaced between $5 \mathrm{~m}$ to $400 \mathrm{~m}$ linear meters) were considered as a cluster, depending on the geographic characteristics of the site; for these clusters the same geographic position was assigned. 


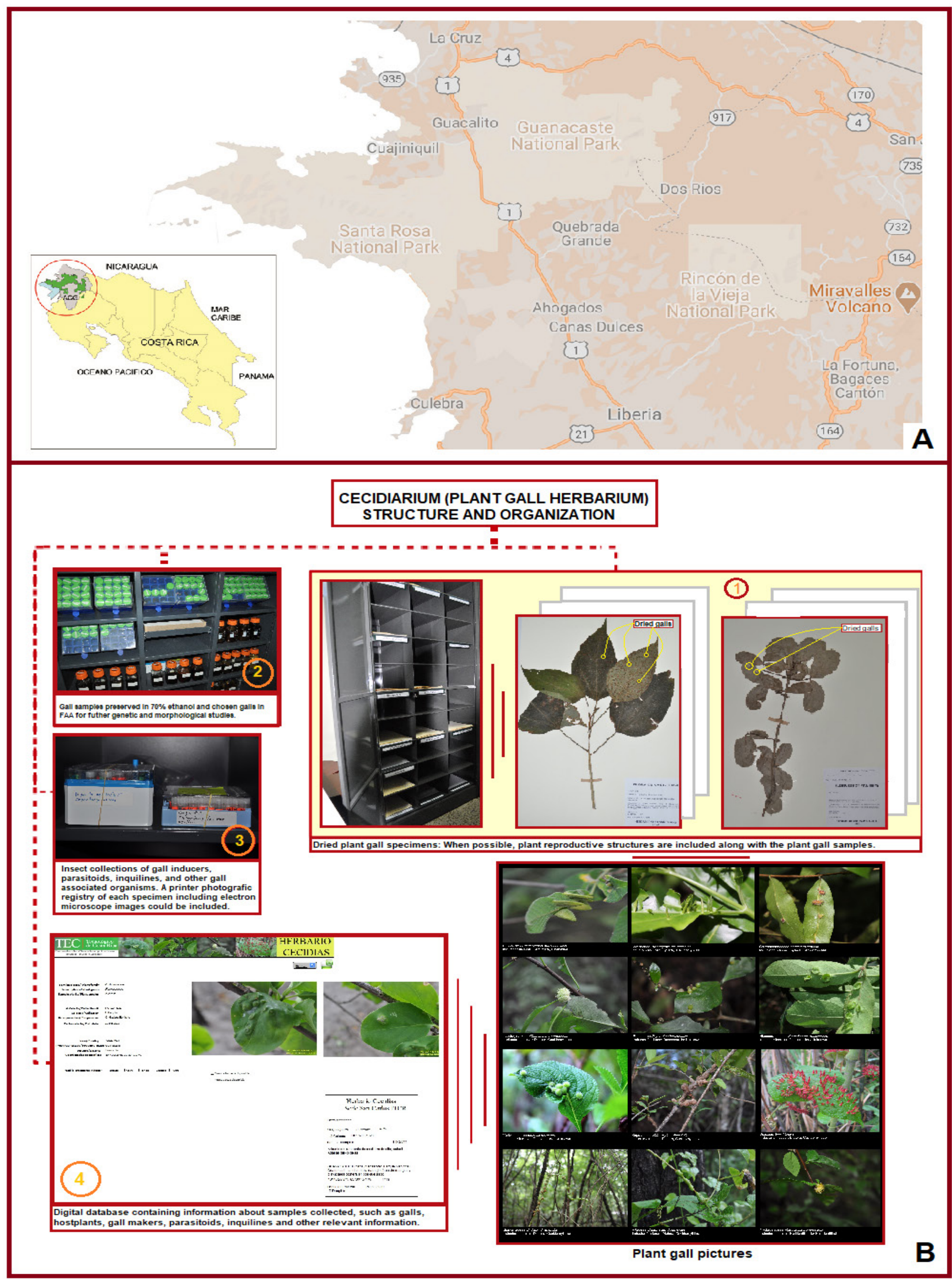

Figure 1. 1A) Guanacaste Conservation Area (Área de Conservación Guanacaste, ACG) map showing the Santa Rosa National Park, Guanacaste National Park, and Rincón de la Vieja National Park sectors. Taken and modified from Área de Conservación Guanacaste- SINAC (https://www.acguanacaste.ac.cr/ index.php), and Google Earth ${ }^{\circledR}$. 1B) Plant Gall Herbarium (cecidiarium) organization. 1) Dried plant gall specimens, 2) Plant gall samples preserved in 70\% ethanol and FAA, 3) Insect collection of gall inducers, parasitoids, and inquilines preserved in $70 \%$ ethanol vials, 4) Digital database containing information about gall morphotypes, host plants, gall makers, associated organisms, sampling sites, etc. 
In addition to the list of host plants harboring galls, the morphological characterization of all gall morphotypes found is provided. Gall morphotypes were used to register plant galls, as well as a reference for the galling insect collection, assuming that each morphotype is unique and each galling species is specific to its host plant (Espírito-Santo \& Fernandez 2007, Abrahamson et al. 1998, Carneiro et al. 2009). The morphological characteristics used in gall differentiation were basic gall form, external color and epidermial structure. Morphotype shape was established according to the most usual morphological classifications found in the literature on this topic (Maia 2001, Urso-Guimarães et al. 2003, Carneiro et al. 2009, Santos et al. 2011a, Saito \& Urso-Guimarães 2012, Isaias et al. 2013). Since these classification criteria could be ambiguous, we classified galls based on their basic general shapes considering that gall morphology could be a mixture of different shapes.

Gall morphotypes were named according to the two first letters from the binomial scientific name, followed by the numerical order of appearance in each plant species, and if necessary, the third letter of the specific epithet might also be used. We propose this nomenclature designation to avoid confusion in the registry of gall morphotypes. Moreover, only detailed literature descriptions with photographs were considered for previous records of plant gall morphotypes.

Adult stages of the gall-inducers and their parasitoids were obtained by rearing galls in plastic bags until the adult emerged. Gall inducers, parasitoids, and inquilines were preserved in plastic vials containing $70 \%$ ethanol and deposited in the cecidiarium. Roberto Espinoza carried out the taxonomic identification of the host plants, and the inductor insects were identified by Paul Hanson as much as possible.

Data from external gall epidermis lignification and trichomecovered galls from deciduous forest areas and evergreen tree areas such as Bosque Viejo were statistically analyzed by a Chi-square test.

\section{Gall morphotype inventory and collection of associated organisms in a specialized herbarium as an integrated biological database}

Inventories of biological specimens are a valuable tool to know and preserve biological diversity; for plant specimens, for instance, a traditional herbarium is an appropriate way to carry out this task. A specialized herbarium of plant galls was created to become a reference collection for Costa Rican plant galls. This herbarium began operating in 2012 and currently has around 400 sample accessions. The collection started with plant galls from the Guanacaste Conservation Area. To date, the herbarium is made up of four basic units: the plant gall collection of dried specimens, selected gall samples preserved in $70 \%$ ethanol (some of them stored at $-70^{\circ} \mathrm{C}$ ), associated insects preserved in $70 \%$ ethanol, and a digital database with all the collected information (Figure 1B). Due to the fact that gall traits change in dried samples, a printed photographic registry of each specimen is included in the collection, and for further morphological studies, a collection of selected galls in FAA (formalin-acetic acid-alcohol) is expected to be included in the future. A database with plant gall data and photographs, as well as information related to their associated organisms, is expected to be available using FileMaker-Pro software or another similar program. This specialized herbarium functions according to appropriated technical standard and collections are maintained in a controlled environment at $20 \mathrm{C}^{\circ}$ with relative humidity between $40-60 \%$.

\section{Results}

A total of eighty-seven species, in seventy genera and forty-four families, of plants that host galls were recorded in the Guanacaste Conservation Area (Table 1). We found one hundred thirty-one morphologically distinct types of plant galls in ACG. The plant families with the highest number of gall morphotypes were Fabaceae (8.4\%), Rubiaceae (7.6\%), Malvaceae (6.1\%), Sapindaceae $(5.3 \%)$, Boraginaceae (4.6\%), and Nyctaginaceae with 4.6\% (Table 2). Sixty plant species harbored one gall morphotype, fifteen had two associated morphotypes, six plant species harbored three gall morphotypes, two species contained four gall morphotypes and three species harbored five morphotypes. The species with the greatest number of galls were Acalypha diversifolia (Euphorbiaceae) and Psychotria horizontalis (Rubiaceae) with four gall morphotypes, as well as Pisonia macranthocarpa (Nyctaginaceae), Sideroxylon obtusifolium (Sapotaceae), and Stegnosperma cubense (Stegnospermataceae) with five morphotypes each.

Some gall samples were so rare that there were not enough to obtain insects, but in many cases, although we had enough plant material, it was not possible to obtain adult insects for identification purposes. Gall-inducer identification to family level was possible in many cases based on the larval stages encountered during the dissections of some selected galls when enough material was available. Nevertheless, even when adult stages were obtained, identification of most insects beyond the family level was complicated by the lack of appropriate taxonomic references, a limitation described by Hanson et al. (2014). Therefore, most of the collected insects remain as unidentified species. The inducing insects that were identified belong to the family Cecidomyiidae (Diptera). Some parasitoids/inquilines (all belonging to the order Hymenoptera) were identified to the family, subfamily or genus level.

Plant gall morphotype description, name and characteristics are presented below under host plant families, genera and species in alphabetical order. They included gall morphology classification, color, epidermial structure, organs attacked, associated organisms as well as host plant description, location and geographical coordinates.

\section{Acanthaceae}

Aphelandra scabra (Vahl) Sm. Morphotype Ap_sc_1 (Figure 2A). Gall description: Irregular shape, white, induced on bud, hairy epidermis. Gall inducer: unknown. Parasitoids/Inquilines: unknown. Plant description: Shrub, nearly $2 \mathrm{~m}$ tall, on top of rock by the river. Location: Guanacaste, Liberia, Curubandé. Guanacaste National Park, Las Pailas Area, gallery forest with remnant trees. Coordinates/Altitude: 10,7749444 N 85,35025 W, 955 m. Registry comments: First gall morphotype record for Guanacaste Conservation Area, Costa Rica, and the world.

Avicennia germinans L. Morphotype Av_ge_1 (Figure 2B). Gall description: Discoid shape, green or yelowish-brown, induced on leaves and veins, glabrous epidermis, protruding on both surfaces of the leaf. Gall inducer: unknown. Parasitoids/Inquilines: unknown. Plant description: Shrub, nearly $3 \mathrm{~m}$ tall, barren. Location: Guanacaste, Liberia, Nacascolo. Guanacaste National Park, Naranjo Beach Area, mangrove and beach area, coastal area in dry-forest. Coordinates/Altitude: 10,78335 N 85,6644861 W, 14 m. Registry comments: Gall morphotype resembles the one described by Oliveira dos Santos et al. (2013). 
Gätjens-Boniche O. et al.

Table 1. Number of gall morphotypes per plant family in ACG (Guanacaste, Costa Rica).

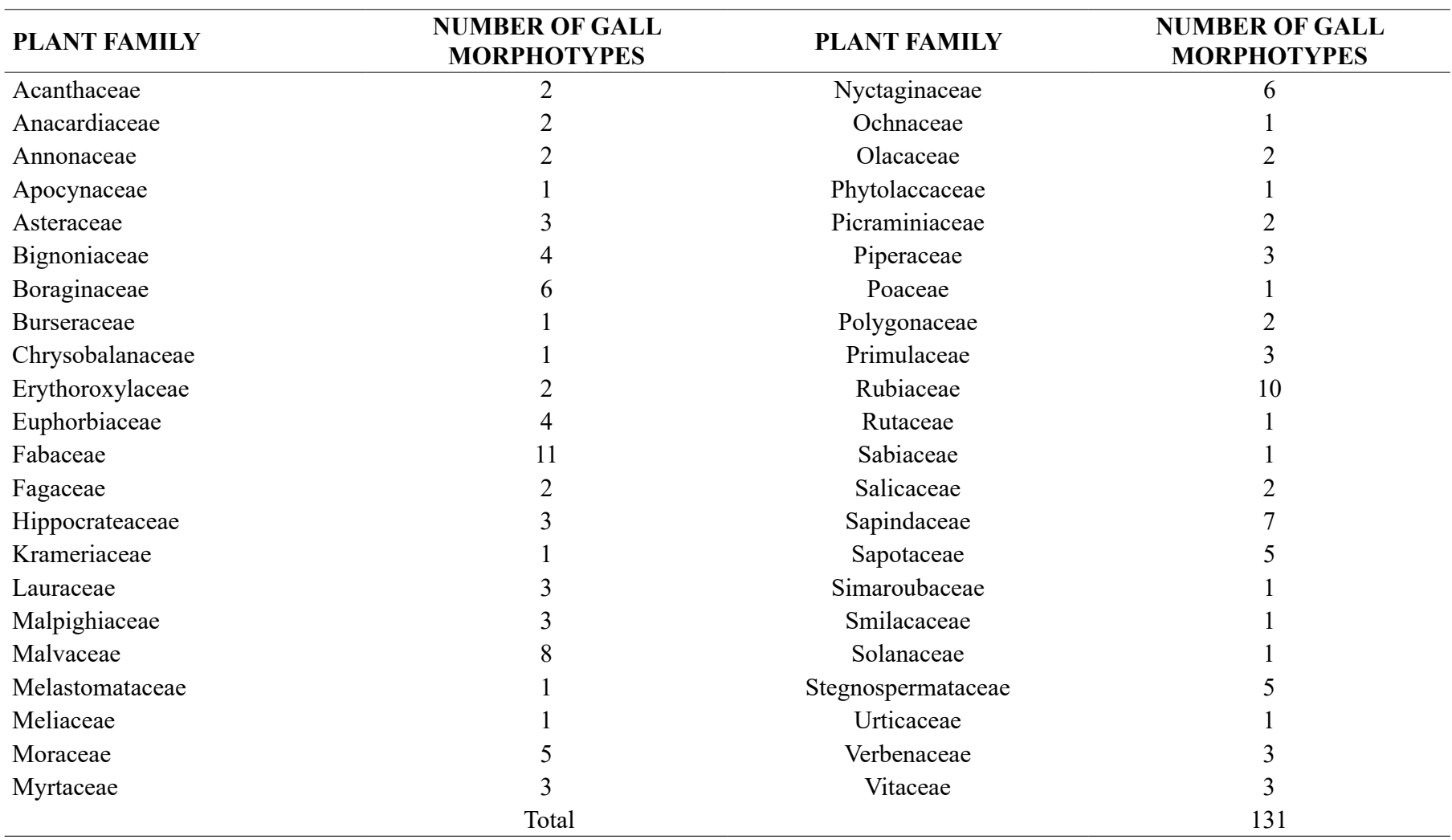

Table 2. Number of gall morphotypes on each plant organ in ACG (Guanacaste, Costa Rica).

\begin{tabular}{lcc}
\hline PLANT ORGAN & N $^{\circ}$ GALL MORPHOTYPES & \% \\
\hline Bud & 9 & 6.87 \\
Fruit & 1 & 0.76 \\
Inflorescence & 1 & 0.76 \\
Leaf midvein & 5 & 3.82 \\
Leaf midvein and petiole & 1 & 0.76 \\
Leaf veins & 4 & 3.05 \\
Leaves & 80 & 61.07 \\
Leaves and buds & 2 & 1.53 \\
Leaves and petiole & 1 & 0.76 \\
Petiole & 4 & 3.05 \\
Stem & 23 & 17.56 \\
Total & $\mathbf{1 3 1}$ & $\mathbf{1 0 0}$ \\
\hline
\end{tabular}

\section{Anacardiaceae}

Astronium graveolens Jacq. Morphotype As_gr_1 (Figure 2C). Gall description: Globular shape, yellowish green to brown at maturity, induced on leaves, lignified epidermis. Glabrous, on the adaxial surface of the leaves. Gall inducer: unknown. Parasitoids/Inquilines: unknown. Plant description: Sapling, nearly $5 \mathrm{~m}$ tall, barren. Location: Guanacaste, Liberia, Nacascolo. Santa Rosa National Park, Bosque Viejo Area between the entrance of the park and La Casona. Coordinates/Altitude: 10,85072 N 85,60796 W, 321 m. Registry comments: Gall recorded by Hanson \& Nishida (2014).

Spondias mombin L. Morphotype Sp_mo_1 (Figure 2D). Gall description: Globular shape, green galls, brown at maturity, located on the adaxial surface of the leaf. Glabrous and lignified epidermis. Gall inducer: unknown. Parasitoids/Inquilines: unknown. Plant description: Tree, nearly $4 \mathrm{~m}$ tall. Location: Guanacaste, La Cruz. Cañas Castilla
Country Estate, along the Sonzapote riverside, area of farms and gallery forests. Coordinates/Altitude: 11,11379167 N 85,57459722 W, 200 m. Registry comments: First gall morphotype record for Guanacaste Conservation Area, Costa Rica, and the world, although two galls induced on this plant species by Cecidomyiidae were reported, without a reference image, by Medianero et al. (2010).

\section{Annonaceae}

Guatteria diospyroides Baill. Morphotype Gu_di_1 (Figure 2E). Gall description: Fusiform shape, brown, induced on stem, lignified epidermis. On the steam nearly the leaf. Gall inducer: unknown. Parasitoids/Inquilines: unknown. Plant description: Small tree, nearly $1.5 \mathrm{~m}$ tall, barren. Alternate leaves, elongated (linear in shape), Woody 

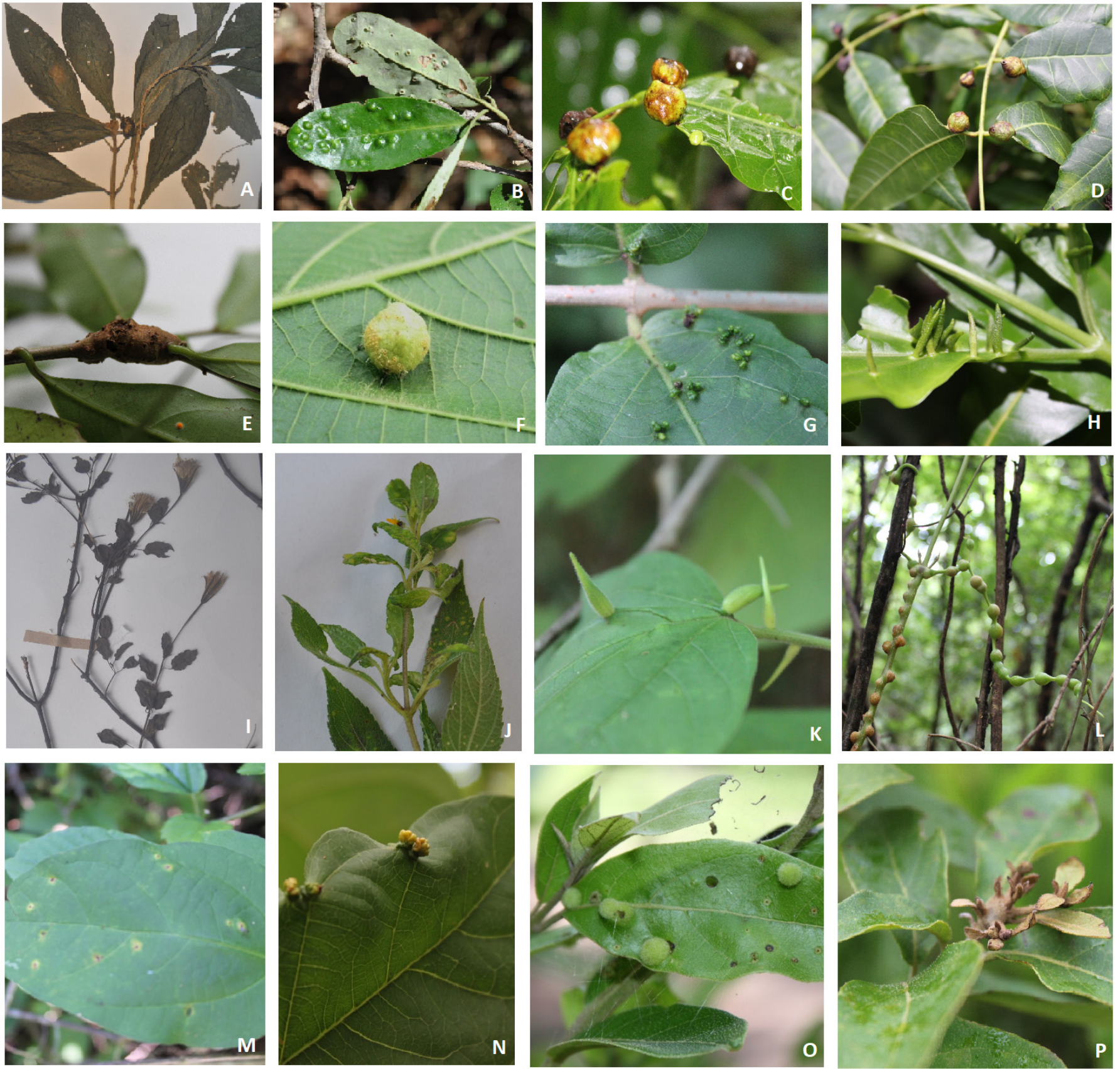

Figure 2. Plant Gall morphotypes recorded in Área de Conservación Guanacaste (ACG), Guanacaste, Costa Rica. 2A) Gall induced in Aphelandra scabra (Vahl) Sm., morphotype Ap sc 1, 2B) Gall induced in Avicennia germinans L., morphotype Av ge 1, 2C) Gall induced in Astronium graveolens Jacq., morphotype As_gr_1,2D) Gall induced in Spondias mombin L., morphotype Sp_mo_1,2E) Gall induced in Guatteria diospyroides Baill., morphotype Gu_di_1, 2F) Gall induced in Sapranthus palanga R.E.Fr., morphotype Sa_pa_1, 2G) Gall induced in Sapranthus palanga R.E.Fr., morphotype Sa_pa_1, 2H) Gall induced in Koanophyllon albicaule (Sch. Bip. ex Klatt) R.M. King \& H. Rob., morphotype Ko_al_1, 2I) Gall induced in Porophyllum punctatum (Mill.) S.F. Blake, morphotype Po_pu_1, 2J) Gall induced in Wedelia sp. Jacq., morphotype We_sp_1, 2K) Gall induced in Arrabidaea patellifera (Schltdl.) Sandwith, morphotype Ar_pa_1, 2L) Gall induced in Cydista diversifolia (Kunth) Miers, morphotype Cy_di_1,2M) Gall induced in Cydista diversifolia (Kunth) Miers, morphotype Cy_di_2, 2N) Gall induced in Pleonotoma variabilis (Jacq.) Miers, morphotype Pl_va_1, 2O) Gall induced in Cordia alliodora (Ruiz \& Pav.) Oken., morphotype Co_al_1, 2P) Gall induced in Cordia alliodora (Ruiz \& Pav.) Oken., morphotype Co_al_2.

stemleaves, and hardened, lustrous dark green in color. Location: Guanacaste, Liberia, Curubandé. Rincón de la Vieja National Park, road to active crater, Los Gemelos Area, rainforest zone. Coordinates/ Altitude: 10,80032 N 85,35 W, 1000 m; 10,93202778 N 85,46 W, 1421 $\mathrm{m}$. Registry comments: First gall morphotype record for Guanacaste Conservation Area, Costa Rica, and the world.
Sapranthus palanga R.E.Fr. Morphotype Sa_pa_1 (Figure 2F). Gall description: Spherical shape, green and yellow, induced on leaves, hairy epidermis. Yellowish green galls on the leaf underside, with trichomes, brown at maturity. Gall inducer: unknown. Parasitoids/ Inquilines: unknown. Plant description: Small tree, $4 \mathrm{~m}$ tall, barren. Location: Guanacaste, Liberia, Nacascolo. Lookout point between 
the main entrance of Santa Rosa National Park and La Casona, old secondary forest area. Coordinates/Altitude: 10,85648 N 85,6106 W, $623 \mathrm{~m}$. Registry comments: First gall morphotype record for Guanacaste Conservation Area, Costa Rica, and the world.

\section{Apocynaceae}

Forsteronia spicata (Jacq.) G. Mey. Morphotype Fo_sp_1 (Figure $2 \mathrm{G})$. Gall description: Irregular shape, green to yellowish at maturity, induced on leaves, glabrous epidermis, protruding on the surface of the leaves. Gall inducer: unknown. Parasitoids/Inquilines: unknown. Plant description: Semi-scandent shrub, nearly $5 \mathrm{~m}$ tall, barren. Woody stem. Opposite leaves, orbicular to ovate in shape. Location: Guanacaste, Liberia, Nacascolo. Santa Rosa National Park, Santa Rosa area, between the Inter-American highway and La Casona, secondary oak forest area. Coordinates/Altitude: 10,86577222 N 85,60990278 W, 290 m; 10,83581 N 85,62347 W, 306 m. Registry comments: First gall morphotype record for Guanacaste Conservation Area, Costa Rica, and the world.

\section{Asteraceae}

Koanophyllon albicaule (Sch. Bip. ex Klatt) R.M. King \& H. Rob. Morphotype Ko_al_1 (Figure 2H). Gall description: Conical shape, green, induced on leaves, glabrous epidermis. Wider at the middle, green, and protruding from the midvein. Gall inducer: Cecidomyiidae. Parasitoids/Inquilines: unknown. Plant description: Shrub, nearly $3 \mathrm{~m}$ tall, barren, acuminated leaves. Location: Guanacaste, Liberia, Nacascolo. Santa Rosa National Park, Bosque Viejo Area between the entrance of the park and La Casona. Coordinates/Altitude: 10,85072 N 85,60796 W, 321 m. Registry comments: First gall morphotype record for Guanacaste Conservation Area, Costa Rica, and the world.

Porophyllum punctatum (Mill.) S.F. Blake. Morphotype Po_pu_1 (Figure 2I). Gall description: Globulous shape, green, induced on leaves, glabrous epidermis. Gall inducer: unknown. Parasitoids/Inquilines: unknown. Plant description: Shrub, nearly $50 \mathrm{~cm}$ tall, white flowers. Opposite simple leaves, $1-1.5 \mathrm{~cm}$ in length. Location: Guanacaste, $\mathrm{La}$ Cruz, Santa Elena. Santa Rosa National Park, Nancite Beach Area, open area over a serpentinite rock. Coordinates/Altitude: 10,80485833 N 85,69909167 W, 10 m. Registry comments: First gall morphotype record for Guanacaste Conservation Area, Costa Rica, and the world.

Wedelia sp. Jacq. Morphotype We_sp_1 (Figure 2J). Gall description: Discoid shape, greenish or yellow, induced on leaves, glabrous epidermis. Gall inducer: unknown. Parasitoids/Inquilines: unknown. Plant description: Herbaceous plant, nearly $0.75 \mathrm{~m}$ tall, pistillate yellow flowers, leaves with serrate margin. Location: Guanacaste, La Cruz. Guanacaste National Park, on the way to the Maritza Biological Station, secondary growth open area, near highvoltage towers. Coordinates/Altitude: 10,95072222 N 85,59705556 W, $272 \mathrm{~m}$. Registry comments: First gall morphotype record for Guanacaste Conservation Area, Costa Rica, and the world.

\section{Bignoniaceae}

Arrabidaea patellifera (Schltdl.) Sandwith. Morphotype Ar_pa_1 (Figure 2K). Gall description: Conical shape, elongated galls, green, induced on leaves, pubescent epidermis. Gall inducer: Cecidomyiidae.
Parasitoids/Inquilines: unknown. Plant description: Vine, barren. Bifoliate leaves with cuspidate apex. Location: Guanacaste, Liberia, Nacascolo. Santa Rosa National Park, Bosque Viejo Area between the entrance of the park and La Casona. Coordinates/Altitude: 10,85072 N 85,60796 W, 321 m; 10,83581 N 85,62347 W, 306 m. Registry comments: First gall morphotype record for Guanacaste Conservation Area, Costa Rica, and the world. However, one gall induced by Cecidomyiidae on this plant species was reported, without a reference image, by Medianero et al. 2010.

Cydista diversifolia (Kunth) Miers. Morphotype Cy_di_1 (Figure 2L). Gall description: Fusiform shape, green or yellow, green to brown color at maturity. Induced on stem, lignified and glabrous epidermis. Gall inducer: Cecidomyiidae. Parasitoids/Inquilines: unknown. Plant description: Understory vine. Leaves with acute apex, bifoliate. Location: Guanacaste, Liberia, Mayorga. Santa Rosa National Park, Bosque Viejo Area between the main entrance of the park and $\mathrm{La}$ Casona. Coordinates/Altitude: 10,85072 N 85,60796 W, $321 \mathrm{~m}$; 10,85648 N 85,6106 W, 323 m; 10,95072222 N 85,59705556 W, 272 m. Registry comments: First gall morphotype record for Guanacaste Conservation Area, Costa Rica, and the world, although a gall induced by Cecidomyiidae on this plant species was reported, without a reference image, by Medianero et al. (2010).

Cydista diversifolia (Kunth) Miers. Morphotype Cy_di_2 (Figure 2M). Gall description: Discoid shape, yellow and red, yellowish spots, brown center, induced on leaves, glabrous epidermis. Gall inducer: unknown. Parasitoids/Inquilines: unknown. Plant description: Understory vine. Leaves with acute apex, bifoliate. Location: Guanacaste, Liberia, Nacascolo. Santa Rosa National Park, start of the road to Naranjo Beach, old secondary growth area with clearings. Coordinates/Altitude: 10,83581 N 85,62347 W, 306 m. Registry comments: First gall morphotype record for Guanacaste Conservation Area, Costa Rica, and the world, although a gall induced by Cecidomyiidae on this plant species was reported, without a reference image, by Medianero et al. (2010).

Pleonotoma variabilis (Jacq.) Miers. Morphotype P1_va_1 (Figure 2N). Gall description: Globular shape, yellowish, induced on leaves, glabrous epidermis. Gall inducer: unknown. Parasitoids/ Inquilines: unknown. Plant description: Shrub of $2 \mathrm{~m}$ tall. Location: Guanacaste, Liberia, Nacascolo. Santa Rosa National Park between the Inter-American highway and La Casona, secondary oak forest area. Coordinates/Altitude: 10,86577222 N 85,60990278 W, 290 m. Registry comments: First gall morphotype record for Guanacaste Conservation Area, Costa Rica, and the world.

\section{Boraginaceae}

Cordia alliodora (Ruiz \& Pav.) Oken. Morphotype Co_al_1 (Figure 2O). Gall description: Spherical shape, green, induced on leaves, hairy epidermis. Tomentose, on the surface of the leaf, brownish. Gall inducer: Cecidomyiidae. Parasitoids/Inquilines: Cecidellis (Pteromalidae); Entedoninae (Eulophidae). Plant description: Shrub, nearly 0,30m$2.5 \mathrm{~m}$ tall, barren. Alternate, simple leaves, lanceolate and pubescent. Location: Guanacaste, Liberia, Nacascolo. Santa Rosa National Park, start of the road to Naranjo Beach, old secondary growth area with clearings. Coordinates/Altitude: 10,83581 N 85,62347 W, $306 \mathrm{~m}$; 10,89222222 N 85,47077778 W, 701 m; 10,92638889 N 85,7292 W, 
45 m; 10,83422222 N 85,6115 W, 324 m. Registry comments: First gall morphotype record for Guanacaste Conservation Area, Costa Rica, and the world, although a gall induced by Cecidomyiidae on this plant species has been reported, without a reference image, by Medianero et al. (2010), Cuevas et al. (2014), and Ley-López et al. (2019).

Cordia alliodora (Ruiz \& Pav.) Oken. Morphotype Co_al_2 (Figure 2P). Gall description: Spherical shape, green and brown, induced on bud, hairy epidermis. Gall inducer: Cecidomyiidae. Parasitoids/Inquilines: Cecidellis (Pteromalidae); Entedoninae (Eulophidae). Plant description: Shrub, nearly $0,30 \mathrm{~m}-2.5 \mathrm{~m}$ tall, barren. Alternate, simple leaves, lanceolate and pubescent. Location: Guanacaste, Liberia, Nacascolo. Guanacaste Conservation Area, Santa Rosa National Park, monument to the heroes of 1856. Coordinates/Altitude: 10,83422222 N 85,6115 W, $324 \mathrm{~m}$. Registry comments: Gall morphotype resembles the one described by Medianero et al. (2010).

Cordia collococca L. Morphotype Co_co_1 (Figure 3A). Gall description: Irregular shape, yellow or white, induced on bud, glabrous epidermis. Gall inducer: Cecidomyiidae. Parasitoids/Inquilines: unknown. Plant description: Tree, nearly $15 \mathrm{~m}$ tall, discoid green fruits. Location: Guanacaste, Liberia, Mayorga. Guanacaste Conservation Area, Góngora, roadside to the Cacao Volcano. Coordinates/Altitude: 10,88683333 N 85,47311111 W, 597 m. Registry comments: First gall morphotype record for Guanacaste Conservation Area, Costa Rica, and the world.

Cordia collococca L. Morphotype Co_co_2 (Figure 3B). Gall description: Discoid shape, green (brown at maturity), induced on leaves, glabrous epidermis. Gall inducer: Cecidomyiidae. Parasitoids/ Inquilines: unknown. Plant description: Tree, nearly $15 \mathrm{~m}$ tall, discoid green fruits. Location: Guanacaste, Liberia, Mayorga. Guanacaste Conservation Area, Cacao Volcano Sector, Cacao Biological Station. Coordinates/Altitude: 10,92658333 N 85,47 W, 1129 m. Registry comments: First gall morphotype record for Guanacaste Conservation Area, Costa Rica, and the world.

Cordia collococca L. Morphotype Co_co_3 (Figure 3C). Gall description: Globular shape, green, induced on petiole, glabrous epidermis. Gall inducer: Cecidomyiidae. Parasitoids/Inquilines: unknown. Plant description: Tree, nearly $15 \mathrm{~m}$ tall, discoid green fruits. Location: Guanacaste, Liberia, Mayorga. Guanacaste Conservation Area, Cacao Volcano Sector, Cacao Biological Station. Coordinates/ Altitude: 10,92658333 N 85,47 W, 1129 m. Registry comments: First gall morphotype record for Guanacaste Conservation Area, Costa Rica, and the world.

Cordia sp. L. Morphotype Co_sp_1 (Figure 3D). Gall description: Conical shape, green, induced on leaves, glabrous epidermis. Gall inducer: unknown. Parasitoids/Inquilines: unknown. Plant description: Tree, nearly $15 \mathrm{~m}$ tall, discoid green fruits. Location: Guanacaste, Liberia, Mayorga. Guanacaste Conservation Area, Góngora, roadside to the Cacao Volcano. Coordinates/Altitude: 10,88683333 N 85,47311111 W, $597 \mathrm{~m}$. Registry comments: First gall morphotype record for Guanacaste Conservation Area, Costa Rica, and the world.

\section{Burseraceae}

Bursera graveolens (Kunth) Triana \& Planch. Morphotype Bu_gr_1 (Figure 3E). Gall description: Cylindrical shape, greenish or yellowbrown, yellow apex, brownish black at senescence, induced on leaves, glabrous epidermis. Gall inducer: unknown. Parasitoids/Inquilines: unknown. Plant description: Shrub, nearly $1 \mathrm{~m}$ tall, procumbent branches, and barren. Location: Guanacaste, La Cruz, Santa Elena. Guanacaste Conservation Area, Murciélago Sector, El Hachal Bay, rocky beach and dry-forest area. Coordinates/Altitude: 10,93408333 N $85,73 \mathrm{~W}, 15 \mathrm{~m}$. Registry comments: First gall morphotype record for Guanacaste Conservation Area, Costa Rica, and the world.

\section{Chrysobalanaceae}

Hirtella racemosa Lam. Morphotype Hi_ra_1 (Figure 3F). Gall description: Cylindrical shape, yellow and red, induced on leaves, soft spines covered with hairs epidermis. With white appendages, reddish pilosity, on the upper or lower surface of the leaf. Gall inducer: unknown. Parasitoids/Inquilines: unknown. Plant description: Shrub, 2,5-3 m tall, by the side of the road. Alternate leaves, with cuspidate apex and entire margin, pilose stipules. Location: Guanacaste, Liberia, Nacascolo. Entrance to the old forest (Bosque Viejo) between the welcome booth and La Casona at Santa Rosa National Park. Coordinates/Altitude: 10,85072 N 85,60796 W, 321 m; 10,85245 N 85,600727 W, 335 m; 10,85072 N $85,60796 \mathrm{~W}, 321 \mathrm{~m}$. Registry comments: First gall morphotype record for Guanacaste Conservation Area, Costa Rica, and the world.

\section{Erythoroxylaceae}

Erythroxylum macrophyllum Cav. Morphotype Er_ma_1 (Figure 3G). Gall description: Spherical shape, beige, induced on leaves, glabrous epidermis. Gall inducer: unknown. Parasitoids/Inquilines: unknown. Plant description: Shrub, nearly $2 \mathrm{~m}$ tall, barren. Leaves with acute apex and entire margin. Location: Guanacaste, Liberia, Curubandé. Guanacaste National Park, Las Pailas Area, in the old secondary forest after the pasture, on the way to the crater. Coordinates/ Altitude: 10,78427778 N 85,3484167 W, 955 m. Registry comments: First gall morphotype record for Guanacaste Conservation Area, Costa Rica, and the world, although a gall on this plant species was reported, without a reference image, by Ley-López et al. (2019).

Erythroxylum macrophyllum Cav. Morphotype Er_ma_2 (Figure $3 \mathrm{H})$. Gall description: Spherical shape, white-yellow, induced on the upper and lower surface of leaves, glabrous epidermis. Gall inducer: unknown. Parasitoids/Inquilines: unknown. Plant description: Shrub, nearly $2 \mathrm{~m}$ tall, barren. Leaves with acute apex and entire margin. Location: Guanacaste, Liberia, Curubandé. Guanacaste National Park, Las Pailas Area, in the old secondary forest after the pasture, on the way to the crater. Coordinates/Altitude: 10,78427778 N 85,3484167 W, 955 m. Registry comments: First gall morphotype record for Guanacaste Conservation Area, Costa Rica, and the world.

\section{Euphorbiaceae}

Acalypha diversifolia Jacq. Morphotype Ac_di_1 (Figure 3I). Gall description: Irregular shape, greenish and yellow, induced on leaves, more or less terminal on branch, glabrous epidermis. Gall inducer: unknown. Parasitoids/Inquilines: unknown. Plant description: Shrub, nearly $1.70-2,5 \mathrm{~m}$ tall, barren, with scandent branches, in understory, barren. Leaves with cuspitade apex and crenate margin. Location: Guanacaste, Liberia, Mayorga. Guanacaste Conservation 

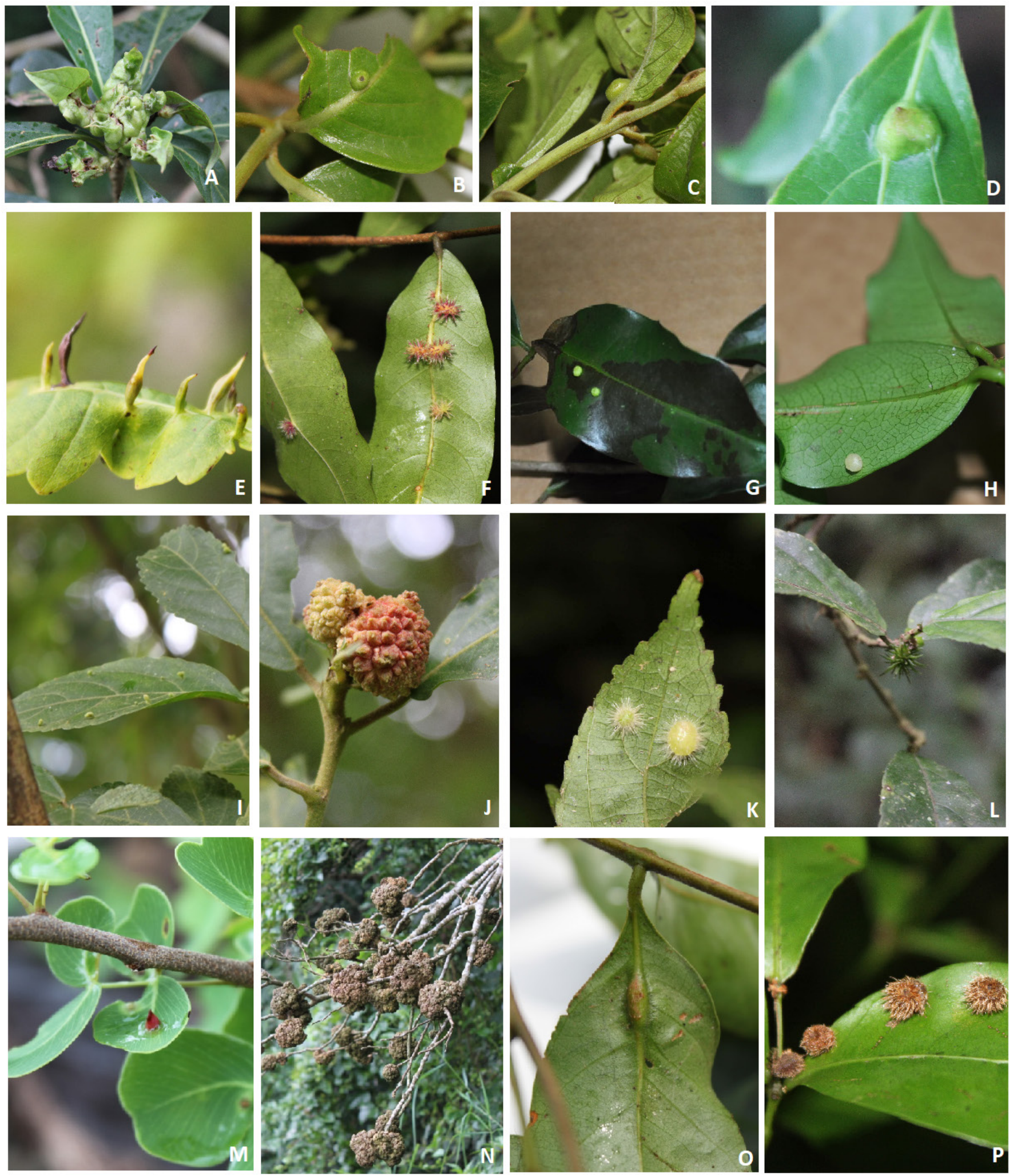

Figure 3. Plant Gall morphotypes recorded in Área de Conservación Guanacaste (ACG), Guanacaste, Costa Rica. 3A) Gall induced in Cordia collococca L., morphotype Co_co_1, 3B) Gall induced in Cordia collococca L., morphotype Co_co_2, 3C) Gall induced in Cordia collococca L., morphotype Co_co_3, 3D) Gall induced in Cordia sp. L., morphotype Co_sp_1, 3E) Gall induced in Bursera graveolens (Kunth) Triana \& Planch., morphotype Bu_gr_1, 3F) Gall induced in Hirtella racemosa Lam., morphotype Hi_ra_1,3G) Gall induced in Erythroxylum macrophyllum Cav., morphotype Er_ma_1,3H) Gall induced in Erythroxylum macrophyllum Cav., morphotype Er_ma_2, 3I) Gall induced in Acalypha diversifolia Jacq., morphotype Ac_di_1, 3J) Gall induced in Acalypha diversifolia Jacq., morphotype Ac_di_2,3K) Gall induced in Acalypha diversifolia Jacq., morphotype Ac_di_3, 3L) Gall induced in Acalypha diversifolia Jacq., morphotype Ac_di_4, 3M) Gall induced in Haematoxylum brasiletto $\mathrm{H}$. Karst., morphotype Ha_br_1, 3N) Gall induced in Inga punctata Willd., morphotype In_pu_1, 3O) Gall induced in Inga sp. Mill., morphotype In_sp_1, 3P) Gall induced in Inga sp. Kunth, morphotype In_sp_2. 
Area, Góngora, roadside to the Cacao Volcano. Coordinates/Altitude: 10,88683333 N 85,47311111 W, 597 m. Registry comments: First gall morphotype record for Guanacaste Conservation Area, Costa Rica, and the world, alhtough a gall on this plant species was reported, without a reference image, by Ley-López et al. (2019).

Acalypha diversifolia Jacq. Morphotype Ac_di_2 (Figure 3J). Gall description: Globular shape, yellow and red, induced on bud, glabrous epidermis. Red-yellowish inflorescense galls. Gall inducer: unknown. Parasitoids/Inquilines: unknown. Plant description: Shrub, nearly 1.70-2,5 m tall, barren, with scandent branches, in understory, barren. Leaves with cuspitade apex and crenate margin. Location: Guanacaste, Liberia, Mayorga. Guanacaste Conservation Area, Góngora, roadside to the Cacao Volcano. Coordinates/Altitude: 10,88683333 N 85,47311111 W, 597 m; 10,89222222 N 85,47077778 W, 701 m. Registry comments: First gall morphotype record for Guanacaste Conservation Area, Costa Rica, and the world, although a gall on this plant species was reported, without a reference image, by Nieves-Aldrey et al. (2008).

Acalypha diversifolia Jacq. Morphotype Ac_di_3 (Figure 3K). Gall description: Spherical shape, greenish and yellow, induced on leaves, hairy epidermis. Galls with spiny projections, green to brownish at senescence, Gall inducer: unknown. Parasitoids/Inquilines: unknown. Plant description: Shrub, nearly 1.70-2,5 m tall, barren, with scandent branches, in understory, barren. Leaves with cuspitade apex and crenate margin. Location: Guanacaste, Liberia, Mayorga. Guanacaste Conservation Area, Góngora, road to the Cacao Volcano, secondary rainforest area, next to the road. Coordinates/Altitude: 10,89222222 N 85,47077778 W, $701 \mathrm{~m}$. Registry comments: First gall morphotype record for Guanacaste Conservation Area, Costa Rica, and the world.

Acalypha diversifolia Jacq. Morphotype Ac_di_4 (Figure 3L). Gall description: Globular shape, green, induced on stem, soft spines epidermis. Gall inducer: unknown. Parasitoids/Inquilines: unknown. Plant description: Shrub, nearly 1.70-2,5 m tall, barren, with scandent branches, in understory, barren. Leaves with cuspitade apex and crenate margin. Location: Guanacaste, Liberia, Mayorga. Guanacaste Conservation Area, Góngora, road to the Cacao Volcano, secondary rainforest area, next to the road. Coordinates/Altitude: 10,89222222 N 85,47077778 W, $701 \mathrm{~m}$. Registry comments: First gall morphotype record for Guanacaste Conservation Area, Costa Rica, and the world.

\section{Fabaceae}

Haematoxylum brasiletto H. Karst. Morphotype Ha_br_1 (Figure 3M). Gall description: Conical shape, red, induced on leaves, glabrous epidermis. Gall inducer: unknown. Parasitoids/Inquilines: Torymus (Torymidae); Pteromalidae. Plant description: Woody sapling, nearly 5 m tall. Location: Guanacaste, La Cruz, Santa Elena. Santa Rosa National Park, Nancite Beach Area, serpentinite rock. Coordinates/ Altitude: 10,80485833 N 85,69909167 W, 10 m. Registry comments: First gall morphotype record for Guanacaste Conservation Area, Costa Rica, and the world.

Inga punctata Willd. Morphotype In_pu_1 (Figure 3N). Gall description: Globular shape, brown, induced on stem, lignified epidermis. Gall inducer: unknown. Parasitoids/Inquilines: Pteromalidae. Plant description: Tree, nearly $10 \mathrm{~m}$ tall, barren. Leaves elliptic in shape. Location: Guanacaste, Liberia, Mayorga. Guanacaste Conservation Area, Cacao Volcano Sector, pasture area next to the forest, start of the trail to the biological station. Coordinates/Altitude: 10,92286111 N 85,46375 W, 1018 m. Registry comments: First gall morphotype record for Guanacaste Conservation Area, Costa Rica, and the world.

Inga sp. Mill. Morphotype In_sp_1 (Figure 3O). Gall description: Elliptical shape, green and brown, induced on leaf midvein, lignified epidermis. Gall inducer: unknown. Parasitoids/Inquilines: unknown. Plant description: Shrub, nearly $4 \mathrm{~m}$ tall, barren. Location: Guanacaste, Liberia, Curubandé. Rincón de la Vieja National Park, road to active crater, Los gemelos Area, forest zone. Coordinates/Altitude: 10,80032 N 85,35 W, 1000 m; 10,78427778 N 85,3484167 W, 955 m. Registry comments: Gall morphotype resembles the one described by Rodriguez et al. (2014).

Inga sp. Kunth. Morphotype In_sp_2 (Figure 3P). Gall description: Spherical shape, brown, induced on the adaxial surface of the leaf, hairy epidermis. Gall inducer: unknown. Parasitoids/Inquilines: unknown. Plant description: Shrub, nearly $4 \mathrm{~m}$ tall, barren. Location: Guanacaste, Liberia, Mayorga. Guanacaste Conservation Area, Cacao Volcano Sector, pasture area next to the forest and start of the trail to the biological station. Coordinates/Altitude: 10,92286111 N 85,46375 W, 1018 m; 10,78427778 N 85,3484167 W, 955 m. Registry comments: Gall morphotype resembles the one described by Rodriguez et al. (2014).

Lonchocarpus felipei N. Zamora. Morphotype Lo_fe_1 (Figure 4A). Gall description: Cylindrical shape, green and yellowish, induced on leaves, glabrous epidermis. Protruding on the underside, densely covering the entire leaf. Gall inducer: Cecidomyiidae. Parasitoids/ Inquilines: unknown. Plant description: Sapling, nearly $4 \mathrm{~m}$ tall, barren. Opposite and ovated in shape, with glabrous underside and pubescent surface. Location: Guanacaste, Liberia, Nacascolo. Santa Rosa National Park, entrance to the lookout point of Naranjo Beach, Bosque Viejo Area. Coordinates/Altitude: 10,80586111 N 85,64 W, 250 m. Registry comments: First gall morphotype record for Guanacaste Conservation Area, Costa Rica, and the world.

Lonchocarpus felipei N. Zamora. Morphotype Lo_fe_2 (Figure 4B). Gall description: Cylindrical shape, green and yellowish, induced on leaves, hairy epidermis. Protruding on the underside, densely covering the entire leaf. Gall inducer: Cecidomyiidae. Parasitoids/Inquilines: unknown. Plant description: Sapling, nearly $4 \mathrm{~m}$ tall, barren. Opposite and ovated in shape, with glabrous underside and pubescent surface. Location: Guanacaste, Liberia, Nacascolo. Santa Rosa National Park, Bosque Viejo Area between the park entrance and La Casona. Coordinates/Altitude: 10,85072 N 85,60796 W, $321 \mathrm{~m}$. Registry comments: First gall morphotype record for Guanacaste Conservation Area, Costa Rica, and the world.

Lonchocarpus paviflorus Benth. Morphotype Lo_pa_1 (Figure 4C). Gall description: Discoid shape, green and yellowish, induced on leaves, hairy epidermis. Truncated at apex, pilose, on the underside of the leaf. Gall inducer: unknown. Parasitoids/Inquilines: unknown. Plant description: Shrub, nearly $2 \mathrm{~m}$ tall, barren. Imparipinnate, opposite compound leaves. Location: Guanacaste, Liberia, Nacascolo. Guanacaste National Park, Santa Rosa area, entrance to the lookout point of Naranjo Beach, secondary forest area. Coordinates/Altitude: 10,80586111 N 85,64 W, 250 m. Registry comments: First gall morphotype record for Guanacaste Conservation Area, Costa Rica, and the world.

Lonchocarpus phaseolifolius Benth. Morphotype Lo_pha_1 (Figure 4D). Gall description: Discoid shape, green, induced on leaves, hairy 

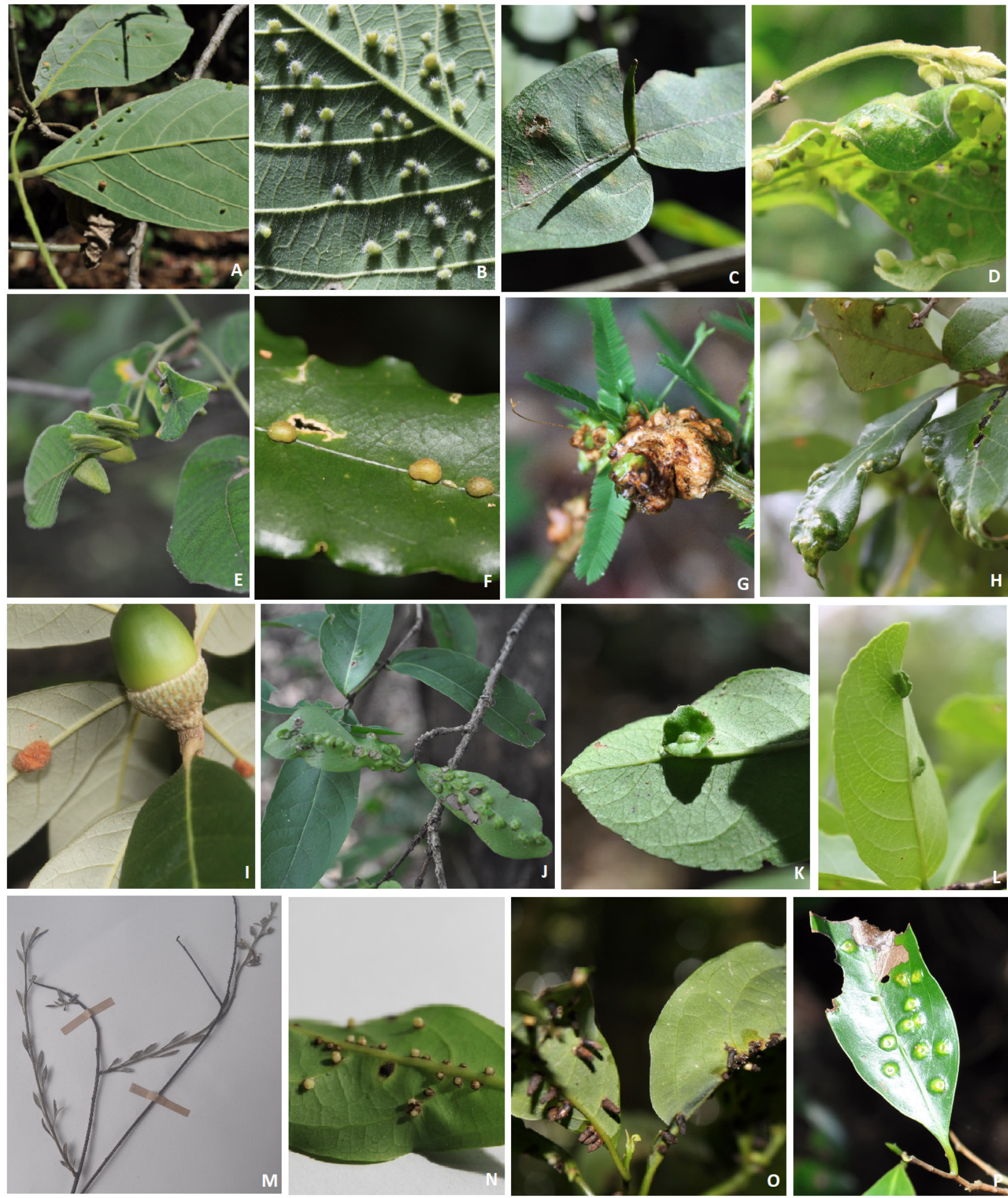

Figure 4. Plant Gall morphotypes recorded in Área de Conservación Guanacaste (ACG), Guanacaste, Costa Rica. 4A) Gall induced in Lonchocarpus felipei N. Zamora, morphotype Lo_fe_1, 4B) Gall induced in Lonchocarpus felipei N. Zamora, morphotype Lo fe 2, 4C) Gall induced in Lonchocarpus paviflorus Benth., morphotype Lo_pa_1,4D) Gall induced in Lonchocarpus phaseolifolius Benth., morphotype Lo_pha_1,4E) Gall induced in Lonchocarpus phlebophyllus Standl \& Steyerm., morphotype Lo phl 1, 4F) Gall induced in Lonchocarpus sp. Kunth, morphotype Lo sp 1, 4G) Gall induced in Senegalia tenuifolia (L.) Britton \& Rose., morphotype Se te 1, 4H) Gall induced in Quercus oleoides Schltdl. \& Cham., morphotype Qu_ol_1, 4I) Gall induced in Quercus oleoides Schltdl. \& Cham., morphotype Qu ol 2, 4J) Gall induced in Semialarium mexicanum (Miers) Mennega, morphotype Se_me_1, 4K) Gall induced in Semialarium mexicanum (Miers) Mennega, morphotype Se_me_2, 4L) Gall induced in Semialarium mexicanum (Miers) Mennega, morphotype Se me 3,4M) Gall induced in Krameria revoluta O. Berg, morphotype Kr re 1, 4N) Gall induced in Belischmiedia costaricensis (Mez \& Pittier) C.K. Allen, morphotype Be_co_1, 40) Gall induced in Belischmiedia costaricensis (Mez \& Pittier) C.K. Allen, morphotype Be_co_2, 4P) Gall induced in Nectandra salicina C.K Allen, morphotype Ne_sa_1. 
epidermis. Truncated at apex, pilose, on the underside of the leaf. Gall inducer: unknown. Parasitoids/Inquilines: unknown. Plant description: Tree, nearly $20 \mathrm{~m}$ tall, fallen, racemes with green fruits, unripe fruits. Location: Guanacaste, La Cruz, Santa Elena. Guanacaste Conservation Area, Murciélago Sector, old secondary growth, road between El Hachal Bay and Murciélago Station. Coordinates/Altitude: 10,92638889 N 85,7292 W, 45 m. Registry comments: First gall morphotype record for Guanacaste Conservation Area, Costa Rica, and the world.

Lonchocarpus phlebophyllus Standl \& Steyerm. Morphotype Lo_phl_1 (Figure 4E). Gall description: Irregular shape, green, induced on leaves, hairy epidermis. Flat on the underside of the leaf. Gall inducer: unknown. Parasitoids/Inquilines: unknown. Plant description: Tree, nearly $4 \mathrm{~m}$ tall, by the side of the river. Location: Guanacaste, La Cruz, Santa Elena. Guanacaste National Park, in the Murciélago Sector, old secondary forest area. Coordinates/Altitude: 10,89686111 N 85,7301111 W, 126 m. Registry comments: First gall morphotype record for Guanacaste Conservation Area, Costa Rica, and the world.

Lonchocarpus sp. Kunth. Morphotype Lo_sp_1 (Figure 4F). Gall description: Globular shape, yellow and brown, induced on leaf midvein, glabrous epidermis. Gall inducer: unknown. Parasitoids/Inquilines: unknown. Plant description: Sapling, nearly $1 \mathrm{~m}$ tall, barren. Leaves with cuspidate apex. Location: Guanacaste, Liberia, Mayorga. Guanacaste Conservation Area, Cacao Volcano Sector, pasture area next to the forest and start of the trail to the biological station. Coordinates/Altitude: 10,92286111 N 85,46375 W, 1018 m. Registry comments: First gall morphotype record for Guanacaste Conservation Area, Costa Rica, and the world, although a gall on this plant species was reported, without a reference image, by Cuevas et al. (2014) and de Souza Mendoca et al. (2014).

Senegalia tenuifolia (L.) Britton \& Rose. Morphotype Se_te_1 (Figure 4G). Gall description: Irregular shape, brown, induced on apical buds, lignified epidermis. Gall inducer: unknown. Parasitoids/Inquilines: unknown. Plant description: Herbaceous plants, nearly $0.4 \mathrm{~m}$ tall, barren. Paripinnate, compound leaves. Location: Guanacaste, Liberia, Nacascolo. Guanacaste Conservation Area, Santa Rosa National Park, roadside near the Bosque Viejo, next to the park entrance. Coordinates/ Altitude: 10,85263889 N 85,607472 W, 310 m. Registry comments: First gall morphotype record for Guanacaste Conservation Area, Costa Rica, and the world.

\section{Fagaceae}

Quercus oleoides Schltdl. \& Cham. Morphotype Qu_ol_1 (Figure 4H). Gall description: Irregular shape, green, yellow at maturity, induced on leaaves, glabrous epidermis. Gall inducer: unknown. Parasitoids/ Inquilines: unknown. Plant description: Small tree, nearly $5 \mathrm{~m}$ tall, by the side of the road. Alternate, simple leaves, with entire margin, underside heavily pubescent. Location: Guanacaste, Liberia, Nacascolo. Santa Rosa National Park, between the Inter-American highway and $\mathrm{La}$ Casona, secondary oak forest area. Coordinates/Altitude: 10,86577222 N 85,60990278 W, 290 m. Registry comments: First gall morphotype record for Guanacaste Conservation Area, Costa Rica, and the world, although a gall on this plant species was reported, without a reference image, by Pascual-Alvarado et al. (2017).

Quercus oleoides Schltdl.\& Cham. Morphotype Qu_ol_2 (Figure 4I). Gall description: Globular shape, orange and brown, induced on the underside of the leaf, hairy epidermis. Gall inducer: unknown. Parasitoids/Inquilines: unknown. Plant description: Small tree, nearly $5 \mathrm{~m}$ tall, by the side of the road. Alternate, simple leaves, with entire margin, underside heavily pubescent. Location: Guanacaste, Liberia, Nacascolo. Lookout point between the main entrance of the Santa Rosa National Park and La Casona, old secondary forest area. Coordinates/ Altitude: 10,85648 N 85,6106 W, 623 m. Registry comments: First gall morphotype record for Guanacaste Conservation Area, Costa Rica, and the world, although a gall on this plant species was reported, without a reference image, by Pascual-Alvarado et al. (2017).

\section{Hippocrateaceae}

Semialarium mexicanum (Miers) Mennega. Morphotype Se_me_1 (Figure 4J). Gall description: Discoid shape, light green, induced on the underside of the leaf, glabrous epidermis. Gall inducer: unknown. Parasitoids/Inquilines: Pteromalidae, Tetrastichinae Eulophidae), Torymus (Torymidae). Plant description: Shrub, nearly $3 \mathrm{~m}$ tall, barren. Location: Guanacaste, Liberia, Nacascolo. Guanacaste National Park, Santa Rosa Area, entrance to the lookout point of Naranjo Beach, secondary forest area. Coordinates/Altitude: 10,81105556 N 85,64 W, $246 \mathrm{~m} ; 10,80485833 \mathrm{~N} \mathrm{85,69909167} \mathrm{W,} 10 \mathrm{~m} ; 10,86577222 \mathrm{~N}$ 85,60990278 W, 290 m. Registry comments: First gall morphotype record for Guanacaste Conservation Area, Costa Rica, and the world.

Semialarium mexicanum (Miers) Mennega. Morphotype Se_me_2 (Figure 4K). Gall description: Discoid shape, green, induced on leaves, glabrous epidermis. Gall inducer: unknown. Parasitoids/Inquilines: Pteromalidae, Tetrastichinae (Eulophidae) Torymus (Torymidae). Plant description: Shrub, nearly $3 \mathrm{~m}$ tall, barren. Location: Guanacaste, Liberia, Nacascolo. Guanacaste National Park, Santa Rosa area, entrance to the lookout point of Naranjo Beach, secondary forest area. Coordinates/Altitude: 10,81105556 N 85,64 W, 246 m. Registry comments: First gall morphotype record for Guanacaste Conservation Area, Costa Rica, and the world.

Semialarium mexicanum (Miers) Mennega. Morphotype Se_me_3 (Figure 4L). Gall description: Discoid shape, green, induced on the underside of the leaf, like a shell, glabrous epidermis. Gall inducer: unknown. Parasitoids/Inquilines: Pteromalidae, Tetrastichinae (Eulophidae) Torymus (Torymidae). Plant description: Shrub, nearly 3 $\mathrm{m}$ tall, barren. Location: Guanacaste, La Cruz, Santa Elena. Santa Rosa National Park, Nancite Beach Area, serpentinite rock. Coordinates/ Altitude: 10,80485833 N 85,69909167 W, 10 m. Registry comments: First gall morphotype record for Guanacaste Conservation Area, Costa Rica, and the world.

\section{Krameriaceae}

Krameria revoluta $\mathrm{O}$. Berg. Morphotype $\mathrm{Kr}$ _re_1 (Figure 4M). Gall description: Elliptical shape, green and brown, induced on stem, hairy epidermis. Gall inducer: unknown. Parasitoids/Inquilines: Tetrastichinae Entedoninae (Eulophidae). Plant description: Herbaceous plant, 30 $\mathrm{cm}$ tall, lilac flowers with white filaments. Alternate, simple leaves, heavily pubescent, approx. $1 \mathrm{~cm}$ in legth. Small lilac flowers. Location: Guanacaste, La Cruz, Santa Elena. Santa Rosa National Park, Nancite Beach Area, open area over a serpentinite rock. Coordinates/Altitude: 10,80485833 N 85,69909167 W, 10 m. Registry comments: First gall 
morphotype record for Guanacaste Conservation Area, Costa Rica, and the world.

\section{Laureaceae}

Belischmiedia costaricensis (Mez \& Pittier) C.K. Allen. Morphotype Be_co_1 (Figure 4N). Gall description: Spherical shape, yellowish and brown, induced on the underside of the leaf, glabrous epidermis. Gall inducer: unknown. Parasitoids/Inquilines: unknown. Plant description: Sapling, nearly $1.70 \mathrm{~m}$ tall, barren, alternate leaves with entire margin. Location: Guanacaste, Liberia, Mayorga. Guanacaste Conservation Area, Cacao Volcano Sector, pasture area next to the forest, start of the trail to the biological station. Coordinates/Altitude: 10,92286111 N 85,46375 W, 1018 m. Registry comments: First gall morphotype record for Guanacaste Conservation Area, Costa Rica, and the world.

Belischmiedia costaricensis (Mez \& Pittier) C.K. Allen. Morphotype Be_co_2 (Figure 4O). Gall description: Conical shape, yellow or brown, induced on the underside of the leaf, glabrous epidermis. Gall inducer: unknown. Parasitoids/Inquilines: unknown. Plant description: Sapling, nearly $1.70 \mathrm{~m}$ tall, barren. Alternate leaves with entire margin. Location: Guanacaste, Liberia, Mayorga. Guanacaste Conservation Area, Cacao Volcano Sector, pasture area next to the forest, start of the trail to the biological station. Coordinates/Altitude: 10,92286111 N 85,46375 W, $1018 \mathrm{~m}$. Registry comments: First gall morphotype record for Guanacaste Conservation Area, Costa Rica, and the world.

Nectandra salicina C.K. Allen. Morphotype Ne_sa_1 (Figure 4P). Gall description: Discoid shape, yellowish in the centre and green on the borders, induced on leaves, glabrous epidermis. Gall inducer: unknown. Parasitoids/Inquilines: Braconidae, Entedoninae (Eulophidae). Plant description: Shrub, nearly $1.5 \mathrm{~m}$ tall, barren. Location: Guanacaste, Liberia, Curubandé. Guanacaste National Park, Las Pailas Area, in the forest after the pasture, on the way to the crater. Coordinates/Altitude: 10,76955556 N 85,34519444 W, 744 m. Registry comments: First gall morphotype record for Guanacaste Conservation Area, Costa Rica, and the world.

\section{Malpighiaceae}

Banisteriopsis cornifolia (Kunth) C.B. Rob. Morphotype Ba_co_1 (Figure 5A). Gall description: Discoid shape, yellowish, induced on leaves, glabrous epidermis. Gall inducer: unknown. Parasitoids/ Inquilines: unknown. Plant description: Shrub, nearly $3 \mathrm{~m}$ tall, with procumbent branches, barren. Location: Guanacaste, Liberia, Nacascolo. Santa Rosa National Park, Bosque Viejo Area between the entrance of the park and La Casona. Coordinates/Altitude: 10,85072 N 85,60796 W, 321 m. Registry comments: First gall morphotype record for Guanacaste Conservation Area, Costa Rica, and the world.

Banisteriopsis cornifolia (Kunth) C.B. Rob. Morphotype Ba_co_2 (Figure 5B). Gall description: Elliptical shape, green or yellowish, induced on leaves, glabrous epidermis. Gall inducer: unknown. Parasitoids/Inquilines: unknown. Plant description: Shrub, nearly $3 \mathrm{~m}$ tall, with procumbent branches, barren. Location: Guanacaste, Liberia, Nacascolo. Santa Rosa National Park, Bosque Viejo Area between the entrance of the park and La Casona. Coordinates/Altitude: 10,85072 N 85,60796 W, 321 m. Registry comments: First gall morphotype record for Guanacaste Conservation Area, Costa Rica, and the world.
Byrsonima crassifolia (L.) Kunth. Morphotype By_cr_1 (Figure 5C). Gall description: Conical shape, green or yellowish, induced on leaves, glabrous epidermis. Gall inducer: unknown. Parasitoids/ Inquilines: unknown. Plant description: Small tree, nearly $2 \mathrm{~m}$ tall, barren. Opposite, simple leaves, medium size, with trichomes on the underside. Location: Guanacaste, La Cruz. Guanacaste National Park, on the way to the Maritza Biological Station, secondary growth area along side the river. Coordinates/Altitude: 10,88683333 N 85,47311111 W, $272 \mathrm{~m}$. Registry comments: First gall morphotype record for Guanacaste Conservation Area, Costa Rica, and the world.

\section{Malvaceae}

Guazuma ulmifolia Lam. Morphotype Gu_ul_1 (Figure 5D). Gall description: Globular shape, yellow and brown, induced on bud, glabrous epidermis. Gall inducer: unknown. Parasitoids/Inquilines: Sycophila, "Eurytoma" (Eurytomidae), Tetrastichinae (Eulophidae). Plant description: Sapling, nearly $3 \mathrm{~m}$ tall, barren. Ovate leaves with dentate margin. Location: Guanacaste, Liberia, Mayorga. Guanacaste Conservation Area, Góngora, roadside to the Cacao Volcano. Coordinates/Altitude: 10,88683333 N 85,47311111 W, 597 m. Registry comments: First gall morphotype record for Guanacaste Conservation Area, Costa Rica, and the world.

Guazuma ulmifolia Lam. Morphotype Gu_ul_2 (Figure 5E). Gall description: Irregular shape, green and yellow, distributed on the glabrous adaxial surface of the leaf, glabrous epidermis. Gall inducer: unknown. Parasitoids/Inquilines: unknown. Plant description: Sapling, nearly $3 \mathrm{~m}$ tall, barren. Ovate leaves with dentate margin. Location: Guanacaste, Liberia, Mayorga. Guanacaste Conservation Area, Góngora, roadside to the Cacao Volcano. Coordinates/Altitude: 10,88683333 N 85,47311111 W, 597 m. Registry comments: First gall morphotype record for Guanacaste Conservation Area, Costa Rica, and the world, although a gall on the same plant organ for this plant species was reported, without a reference image, by Coelho et al. (2014) but gall description doesn't match.

Guazuma ulmifolia Lam. Morphotype Gu_ul_3 (Figure 5F). Gall description: Globular shape, green, induced on stem, hairy epidermis. Gall inducer: unknown. Parasitoids/Inquilines: unknown. Plant description: Sapling, nearly $3 \mathrm{~m}$ tall, barren. Ovate leaves with dentate margin. Location: Guanacaste, Liberia, Mayorga. Guanacaste Conservation Area, Góngora, roadside to the Cacao Volcano. Coordinates/Altitude: 10,89222222 N 85,47077778 W, 701 m. Registry comments: First gall morphotype record for Guanacaste Conservation Area, Costa Rica, and the world.

Hampea appendiculata (Donn. Sm.) Standl. Morphotype Ha_ap_1 (Figure 5G). Gall description: Irregular shape, yellow, induced on leaves, glabrous epidermis. Gall inducer: unknown. Parasitoids/Inquilines: unknown. Plant description: Sapling, nearly $1.5 \mathrm{~m}$ tall, barren. Location: Guanacaste, Liberia, Mayorga. Guanacaste Conservation Area, Cacao Volcano Sector, pasture area next to the forest and start of the trail to the biological station. Coordinates/Altitude: 10,92286111 N 85,46375 W, 1018 m. Registry comments: First gall morphotype record for Guanacaste Conservation Area, Costa Rica, and the world.

Malvaviscus arboreus Dill. ex Cav. Morphotype Ma_ar_1 (Figure 5H). Gall description: Spherical shape, green, induced on leaves, hairy epidermis. Gall inducer: Cecidomyiidae. Parasitoids/Inquilines: 

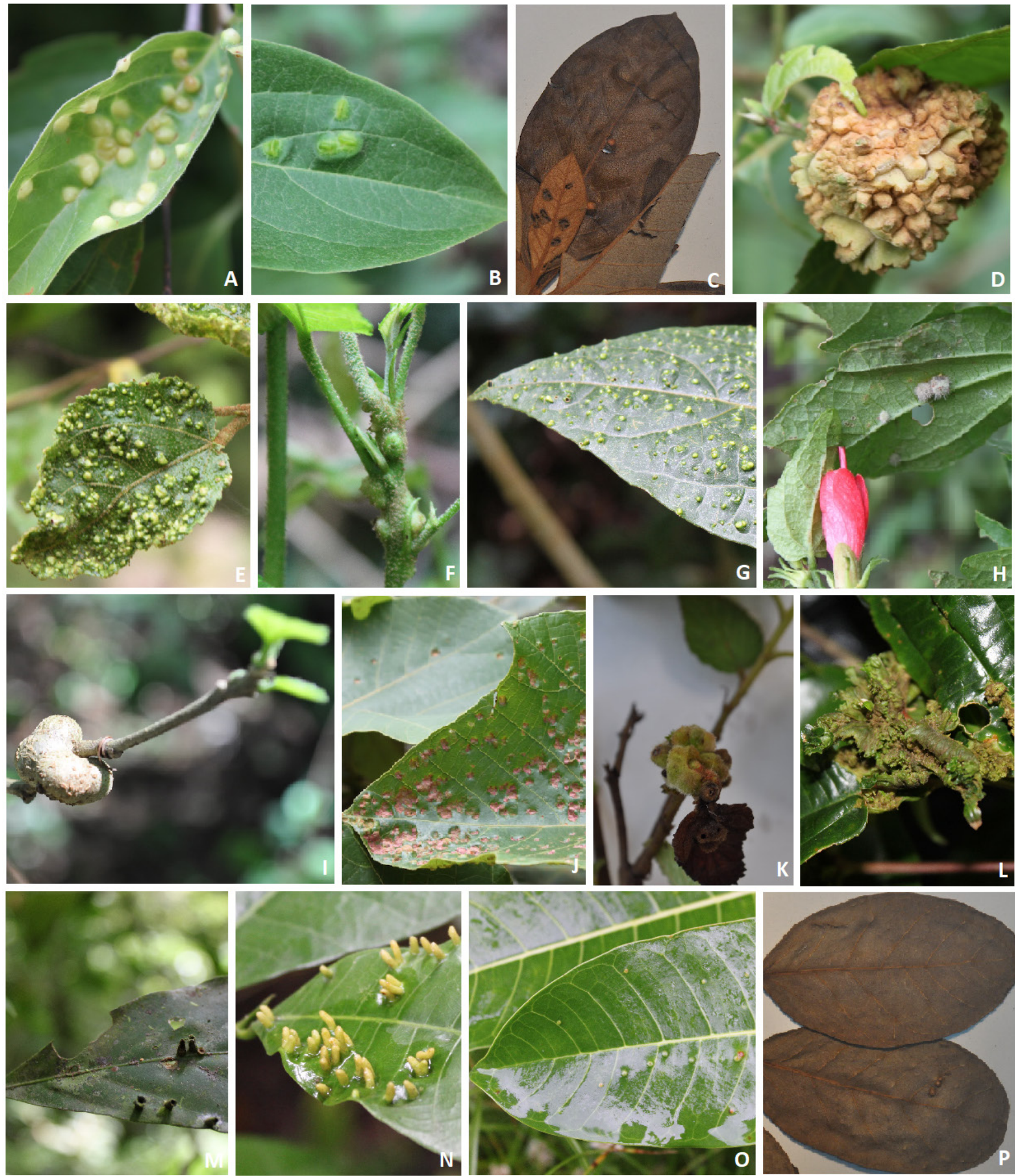

Figure 5. Plant Gall morphotypes recorded in Área de Conservación Guanacaste (ACG), Guanacaste, Costa Rica. 5A) Gall induced in Banisteriopsis cornifolia (Kunth) C.B. Rob., morphotype Ba_co_1, 5B) Gall induced in Banisteriopsis cornifolia (Kunth) C.B. Rob., morphotype Ba_co_2, 5C) Gall induced in Byrsonima crassifolia (L.) Kunth, morphotype By_cr_1,5D) Gall induced in Guazuma ulmifolia Lam., morphotype Gu_ul_1,5E) Gall induced in Guazuma ulmifolia Lam., morphotype Gu_ul_2, 5F) Gall induced in Guazuma ulmifolia Lam., morphotype Gu_ul_3, 5G) Gall induced in Hampea appendiculata (Donn. Sm.) Standl., morphotype Ha_ap_1, 5H) Gall induced in Malvaviscus arboreus Dill. ex Cav., morphotype Ma_ar_1, 5I) Gall induced in Malvaviscus arboreus Dill. ex Cav., morphotype Ma_ar_2, 5J) Gall induced in Ochroma pyramidale (Cav. ex Lam.) Urb., morphotype Oc_py_1, 5K) Gall induced in Waltheria indica L., morphotype Wa in_1, 5L) Gall induced in Miconia sp. Ruiz \& Pav., morphotype Mi_sp_1, 5M) Gall induced in Guarea glabra Kunth. , morphotype Gu_gl_1, 5N) Gall induced in Brosimum alicastrum Swartz, morphotype Br_al_1, 50) Gall induced in Ficus croata (Miq.) Miq., morphotype Fi_cr_1, 5P) Gall induced in Ficus ovalis Desf. ex Willd., morphotype Fi_ov_1. 
unknown. Plant description: Shrub, $1.5 \mathrm{~m}$ tall, red flowers, on top of rock by the river. Location: Guanacaste, Liberia, Curubandé. Guanacaste National Park, Las Pailas Area, in the forest after the fumaroles. Coordinates/Altitude: 10,85072 N 85,60796 W, 321 m. Registry comments: First gall morphotype record for Guanacaste Conservation Area, Costa Rica, and the world.

Malvaviscus arboreus Dill. ex Cav. Morphotype Ma_ar_2 (Figure 5I). Gall description: Globular shape, brown, induced on stem, lignified epidermis. Gall inducer: unknown. Parasitoids/Inquilines: unknown. Plant description: Shrub, $1.5 \mathrm{~m}$ tall, red flowers, on top of rock by the river. Location: Guanacaste, Liberia, Nacascolo. Santa Rosa National Park, around La Casona at Santa Rosa National Park. Coordinates/ Altitude: 10,76955556 N 85,34519444 W, 745 m; 10,77722222 N 85,35025 W, 955 m; 10,88683333 N 85,47311111 W, 597 m. Registry comments: First gall morphotype record for Guanacaste Conservation Area, Costa Rica, and the world.

Ochroma pyramidale (Cav. ex Lam.) Urb. Morphotype Oc_py_1 (Figure 5J). Gall description: Irregular shape, reddish-brown on the adaxial surface of the leaf and white on the underside of the leaf, induced on leaves, hairy epidermis. Gall inducer: unknown. Parasitoids/Inquilines: unknown. Plant description: Small tree, nearly $1.7 \mathrm{~m}$ tall, barren. Location: Guanacaste, Liberia, Mayorga. Guanacaste Conservation Area, Góngora, roadside to the Cacao Volcano, next to the Góngora River. Coordinates/ Altitude: 10,83422222 N 85,6115 W, 569 m. Registry comments: First gall morphotype record for Guanacaste Conservation Area, Costa Rica, and the world, although a gall on this plant species was reported, without a reference image, by Ley-López et al. 2019.

Waltheria indica L. Morphotype Wa_in_1 (Figure 5K). Gall description: Globular shape, green galls, yellowish/redish at maturity, brown, on the underside of the leaf and petiole, hairy epidermis. Gall inducer: unknown. Parasitoids/Inquilines: unknown. Plant description: Small tree, nearly $5 \mathrm{~m}$ tall, by the side of the road. Location: Guanacaste, La Cruz. Guanacaste National Park, on the way to the Maritza Biological Station, secondary growth open area, near high-voltage towers. Coordinates/Altitude: 10,95072222 N 85,59705556 W, 272 m. Registry comments: Gall recorded by Figueiredo et al. 2014.

\section{Melastomataceae}

Miconia sp. Ruiz \& Pav. Morphotype Mi_sp_1 (Figure 5L). Gall description: Irregular shape, green and brown, induced on bud and leaves, glabrous epidermis. Gall inducer: unknown. Parasitoids/ Inquilines: Torymus (Torymidae), Eupelmidae, Pteromalidae. Plant description: Shrub, nearly $2.5 \mathrm{~m}$ tall, barren. Location: Guanacaste, Liberia, Mayorga. Guanacaste Conservation Area, Cacao Volcano Sector, pasture area next to the forest, start of the trail to the biological station. Coordinates/Altitude: 10,93202778 N 85,46 W, $1277 \mathrm{~m}$. Registry comments: First gall morphotype record for Guanacaste Conservation Area, Costa Rica, and the world, although a gall on this plant species has been reported, without a reference image, by De Souza (2014), Medianero et al. (2014), and Ley-López et al. (2019).

\section{Meliaceae}

Guarea glabra Kunth. Morphotype Gu_gl_1 (Figure 5M). Gall description: Cylindrical shape, green, on adaxial and abaxial surface of the leaf, glabrous epidermis. Gall inducer: unknown. Parasitoids/ Inquilines: unknown. Plant description: Shrub, nearly $4 \mathrm{~m}$ tall, barren. Location: Guanacaste, Liberia, Mayorga. Guanacaste Conservation Area, Góngora, road to the Cacao Volcano, secondary rainforest area, next to the road. Coordinates/Altitude: 10,89222222 N 85,47077778 W, $701 \mathrm{~m}$. Registry comments: First gall morphotype record for Guanacaste Conservation Area, Costa Rica, and the world.

\section{Moraceae}

Brosimum alicastrum Swartz. Morphotype $\mathrm{Br}$ al_1 (Figure 5N). Gall description: Cylindrical shape, yellowish and brown, induced on leaves, glabrous epidermis. Gall inducer: unknown. Parasitoids/ Inquilines: unknown. Plant description: Small tree, nearly $3 \mathrm{~m}$ tall, barren. Location: Guanacaste, Liberia, Nacascolo. Guanacaste National Park, Santa Rosa area, entrance to the lookout point of Naranjo Beach, secondary forest area. Coordinates/Altitude: 10,85072 N 85,60796 W, 292 m; 10,80586111 N 85,64 W, 250 m; 10,85072 N 85,60796 W, 321 $\mathrm{m}$. Registry comments: First gall morphotype record for Guanacaste Conservation Area, Costa Rica, and the world, although a gall on this plant species has been reported, without a reference image, by Cuevas et al. (2004), Cuevas et al. (2014), and Ley-López et al. (2019).

Ficus croata (Miq.) Miq. Morphotype Fi_cr 1 (Figure 5O). Gall description: Discoid shape, yellowish or red, induced on leaves, glabrous epidermis. Gall inducer: Cecidomyiidae. Parasitoids/Inquilines: unknown. Plant description: Tree, nearly $15 \mathrm{~m}$ tall, barren. Location: Guanacaste, Liberia, Nacascolo. Santa Rosa National Park, around the historic Hacienda La Casona, isolated trees alongside the old corral. Coordinates/Altitude: 10,83382 N 85,61269 W, 307 m. Registry comments: First gall morphotype record for Guanacaste Conservation Area, Costa Rica, and the world.

Ficus ovalis Desf. ex Willd. Morphotype Fi_ov_1 (Figure 5P). Gall description: Globular shape, green, induced on leaves, glabrous epidermis. Gall inducer: unknown. Parasitoids/Inquilines: unknown. Plant description: Tree, nearly $15 \mathrm{~m}$ tall, pedunculated infructescence, yellow, one or more by leaf bud. Alternate leaves, in several different sizes. Location: Guanacaste, Liberia, Nacascolo. Santa Rosa National Park, around the historic Hacienda La Casona, isolated trees alongside the old corral. Coordinates/Altitude: 10,83382 N 85,61269 W, 307 m. Registry comments: First gall morphotype record for Guanacaste Conservation Area, Costa Rica, and the world.

Pseudolmedia glabrata (Liebm.) C.C. Berg. Morphotype Ps_gl_1 (Figure 6A). Gall description: Conical shape, green and yellow, induced on leaves, glabrous epidermis. Gall inducer: unknown. Parasitoids/ Inquilines: unknown. Plant description: Small tree, nearly $3 \mathrm{~m}$ tall, milky secretion, barren. Location: Guanacaste, Liberia, Mayorga. Guanacaste Conservation Area, Cacao Volcano Sector, next to the road. Coordinates/ Altitude: 10,88683333 N 85,47311111 W, 597 m. Registry comments: First gall morphotype record for Guanacaste Conservation Area, Costa Rica, and the world.

Pseudolmedia mollis (Liebm.) C.C. Berg. Morphotype Ps_mo_1 (Figure 6B1/6B2). Gall description: Globular shape, green on the adaxial surface of the leaf, greenish-white and pilose on the abaxial surface of the leaf, glabrous epidermis. Gall inducer: unknown. Parasitoids/ Inquilines: unknown. Plant description: Sapling, nearly $3 \mathrm{~m}$ tall, with milky secretion, barren. Location: Guanacaste, Liberia, Mayorga. 

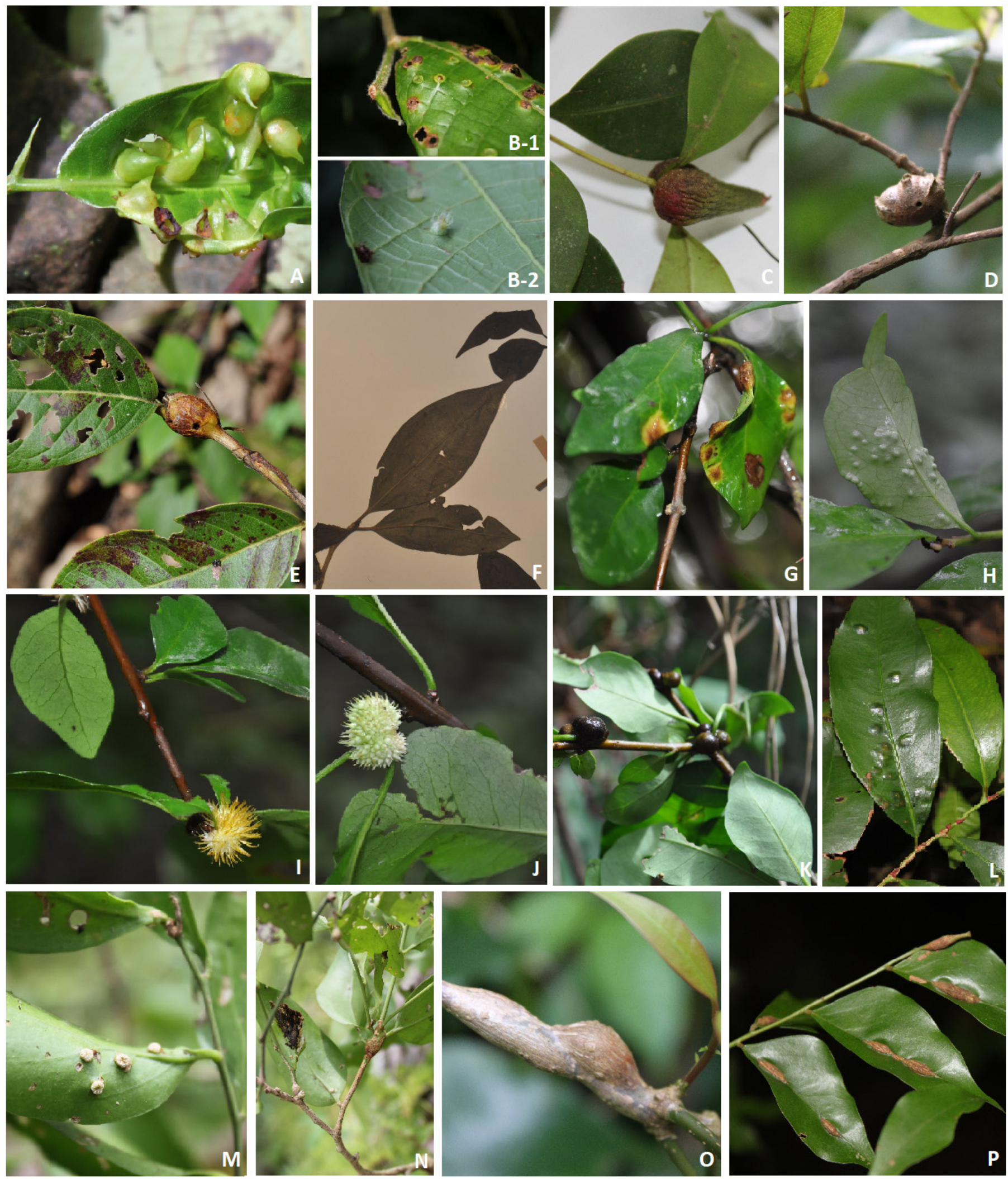

Figure 6. Plant Gall morphotypes recorded in Área de Conservación Guanacaste (ACG), Guanacaste, Costa Rica. 6A) Gall induced in Pseudolmedia glabrata (Liebm.) C.C. Berg, morphotype Ps gl_1,6B1/6B2) Gall induced in Pseudolmedia mollis (Liebm.) C.C. Berg, morphotype Ps_mo_1,6C) Gall induced in Eugenia sp. (Miq.) Miq., morphotype Eu_sp_1,6D) Gall induced in Myrcia splendens (Sw.) DC., morphotype My_sp_1,6E) Gall induced in Psidium guajava L., morphotype Ps_gu_1, 6F) Gall induced in sp. Ruiz \& Pav., morphotype Ne_sp_1,6G) Gall induced in Pisonia macranthocarpa (Donn. Sm.) Donn. Sm., morphotype Pi_ma_1, 6H) Gall induced in Pisonia macranthocarpa (Donn. Sm.) Donn. Sm., morphotype Pi_ma_2, 6I) Gall induced in Pisonia macranthocarpa (Donn. Sm.) Donn. Sm., morphotype Pi_ma_3, 6J) Gall induced in Pisonia macranthocarpa (Donn. Sm.) Donn. Sm., morphotype Pi_ma 4, 6K) Gall induced in Pisonia macranthocarpa (Donn. Sm.) Donn. Sm., morphotype Pi_ma_5, 6L) Gall induced in Ouratea lucens (Kunth.) Engl., morphotype Ou lu 1,6M) Gall induced in Schoepfia schreberi J.F. Gmel., morphotype Sc sc 1, 6N) Gall induced in Schoepfia schreberi J.F. Gmel., morphotype Sc_sc_2,60) Gall induced in Trichostigma polyandrum (Loes.) H. Walter, morphotype Tr_po_1,6P) Gall induced in Picramnia antidesma Sw., morphotype Pi_an_1. 
Guanacaste Conservation Area, Cacao Volcano Sector, pasture area next to the forest, start of the trail to the biological station. Coordinates/ Altitude: 10,92286111 N 85,46375 W, 1018 m. Registry comments: First gall morphotype record for Guanacaste Conservation Area, Costa Rica, and the world.

\section{Myrtaceae}

Eugenia sp. (Miq.) Miq. Morphotype Eu_sp_1 (Figure 6C). Gall description: Conical shape, greenish and reddish, induced on stem, glabrous epidermis. Gall inducer: unknown. Parasitoids/Inquilines: unknown. Plant description: Shrub, nearly 0,5 m tall, barren. Location: Guanacaste, Liberia, Mayorga. Guanacaste Conservation Area, Cacao Volcano Sector, Cacao Mountain range. Coordinates/Altitude: 10,93202778 N 85,46 W, 1421 m. Registry comments: First gall morphotype record for Guanacaste Conservation Area, Costa Rica, and the world.

Myrcia splendens (Sw.) DC. Morphotype My_sp_1 (Figure 6D). Gall description: Globular shape, brown, induced on stem, lignified epidermis. Gall inducer: unknown. Parasitoids/Inquilines: unknown. Plant description: Small tree, nearly $2 \mathrm{~m}$ tall, barren. Location: Guanacaste, Liberia, Mayorga. Guanacaste Conservation Area, Góngora, road to the Cacao Volcano, sedimentary rock area next to the Góngora River. Coordinates/Altitude: 10,83422222 N 85,6115 W, 629 m. Registry comments: First gall morphotype record for Guanacaste Conservation Area, Costa Rica, and the world, although a gall on this plant species was reported, without a reference image, by Ley-López et al. (2019).

Psidium guajava L. Morphotype Ps_gu_1 (Figure 6E). Gall description: Elliptical shape, brown, induced on stem, lignified epidermis. Gall inducer: unknown. Parasitoids/Inquilines: unknown. Plant description: Sapling, nearly $0.5 \mathrm{~m}$ tall, barren. Location: Guanacaste, La Cruz. Guanacaste National Park, on the way to the Maritza Biological Station, secondary growth open area, near highvoltage towers. Coordinates/Altitude: 10,95072222 N 85,59705556 W, $272 \mathrm{~m}$. Registry comments: First gall morphotype record for Guanacaste Conservation Area, Costa Rica, and the world, although a gall on this plant species was reported, without a reference image, by Maia (2012).

\section{Nyctaginaceae}

Neea sp. Ruiz \& Pav. Morphotype Ne_sp_1 (Figure 6F). Gall description: Fusiform shape, green, induced on leaves, glabrous epidermis. Gall inducer: unknown. Parasitoids/Inquilines: unknown. Plant description: Shurb, nearly $1.5 \mathrm{~m}$ tall, barren. Location: Guanacaste, Liberia, Curubandé. Rincón de la Vieja National Park, forest area on the way to active crater. Coordinates/Altitude: 10,78427778 N 85,3484167 W, 955 m. Registry comments: Similar to gall recorded by Maia (2014).

Pisonia macranthocarpa (Donn. Sm.) Donn. Sm. Morphotype Pi_ma_1 (Figure 6G). Gall description: Irregular shape, yellow and brown, induced on leaves, glabrous epidermis. Gall inducer: unknown. Parasitoids/Inquilines: unknown. Plant description: Shrub, nearly 2.5 m tall, barren. Location: Guanacaste, La Cruz, La Cruz. Guanacaste National Park, on the way to the Maritza Biological Station, secondary growth area alongside the river. Coordinates/Altitude: 10,95072222
N 85,59705556 W, 272 m. Registry comments: First gall morphotype record for Guanacaste Conservation Area, Costa Rica, and the world.

Pisonia macranthocarpa (Donn. Sm.) Donn. Sm. Morphotype Pi_ma_2 (Figure 6H). Gall description: Irregular shape, green, induced on leaves, glabrous epidermis. Gall inducer: Cecidomyiidae. Parasitoids/Inquilines: unknown. Plant description: Shrub, nearly $4 \mathrm{~m}$ tall, unripe fruit are light green. Location: Guanacaste, La Cruz, La Cruz. Guanacaste National Park, on the way to the Maritza Biological Station, secondary growth area along the river. Coordinates/Altitude: 10,95072222 N 85,59705556 W, 272 m. Registry comments: First gall morphotype record for Guanacaste Conservation Area, Costa Rica, and the world.

Pisonia macranthocarpa (Donn. Sm.) Donn. Sm. Morphotype Pi_ ma_3 (Figure 6I). Gall description: Spherical shape, yellow, induced on bud, soft spines on epidermis. Gall inducer: Cecidomyiidae. Parasitoids/ Inquilines: unknown. Plant description: Shrub, nearly $2 \mathrm{~m}$ tall, barren. Location: Guanacaste, La Cruz, La Cruz. Guanacaste National Park, on the way to the Maritza Biological Station, secondary growth area along the river. Coordinates/Altitude: 10,95072222 N 85,59705556 W, 272 m. Registry comments: First gall morphotype record for Guanacaste Conservation Area, Costa Rica, and the world.

Pisonia macranthocarpa (Donn. Sm.) Donn. Sm. Morphotype Pi_ma_4 (Figure 6J). Gall description: Globular shape, white, induced on bud, soft spines on epidermis. Gall inducer: unknown. Parasitoids/ Inquilines: unknown. Plant description: Shrub, nearly $2 \mathrm{~m}$ tall. Location: Guanacaste, La Cruz. Guanacaste National Park, on the way to the Maritza Biological Station, secondary growth area alongside the river. Coordinates/Altitude: 10,95072222 N 85,59705556 W, 272 m. Registry comments: First gall morphotype record for Guanacaste Conservation Area, Costa Rica, and the world.

Pisonia macranthocarpa (Donn. Sm.) Donn. Sm. Morphotype Pi_ma_5 (Figure 6K). Gall description: Globular shape, brownish, induced on stem, lignified epidermis. Gall inducer: unknown. Parasitoids/Inquilines: unknown. Plant description: Shrub, nearly $2 \mathrm{~m}$ tall. Location: Guanacaste, La Cruz. Guanacaste National Park, on the way to the Maritza Biological Station, secondary growth area along the river. Coordinates/Altitude: 10,95072222 N 85,59705556 W, 272 m. Registry comments: First gall morphotype record for Guanacaste Conservation Area, Costa Rica, and the world.

\section{Ochnaceae}

Ouratea lucens (Kunth.) Engl. Morphotype Ou_lu_1 (Figure 6L). Gall description: Discoid shape, green (concolorous) to brownish yellow galls on leaves, glabrous epidermis. Gall inducer: unknown. Parasitoids/Inquilines: unknown. Plant description: Understory sapling, with red stipules. Location: Guanacaste, Liberia, Nacascolo. Entrance to the old forest (Bosque Viejo), between the welcome booth and $\mathrm{La}$ Casona at Santa Rosa National Park. Coordinates/Altitude: 10,85072 N 85,60796 W, $321 \mathrm{~m}$. Registry comments: Similar to gall recorded by Bergamini et al. (2017).

\section{Olacaceae}

Schoepfia schreberi J.F. Gmel. Morphotype Sc_sc_1 (Figure 6M). Gall description: Discoid shape, white, induced on leaves, glabrous 
epidermis. Gall inducer: Cecidomyiidae. Parasitoids/Inquilines: unknown. Plant description: Shrub, $3 \mathrm{~m}$ tall, by the side of the road. Location: Guanacaste, Liberia, Nacascolo. Entrance to the old forest (Bosque Viejo), between the welcome booth and La Casona at Santa Rosa National Park. Coordinates/Altitude: 10,8336278 N 85,6132333 W, 292 m. Registry comments: First gall morphotype record for Guanacaste Conservation Area, Costa Rica, and the world.

Schoepfia schreberi J.F. Gmel. Morphotype Sc_sc_2 (Figure 6N). Gall description: Elliptical shape, brown, induced on stem, lignifiedglabrous epidermis. Gall inducer: unknown. Parasitoids/Inquilines: unknown. Plant description: Shrub, $3 \mathrm{~m}$ tall, by the side of the road. Location: Guanacaste, Liberia, Nacascolo. Entrance to the old forest (Bosque Viejo), between the welcome booth and La Casona at Santa Rosa National Park. Coordinates/Altitude: 10,8336278 N 85,6132333 W, 292 m. Registry comments: First gall morphotype record for Guanacaste Conservation Area, Costa Rica, and the world.

\section{Phytolaccaceae}

Trichostigma polyandrum (Loes.) H. Walter. Morphotype Tr_po_1 (Figure 6O). Gall description: Fusiform shape, brown, induced on stem, lignified, and glabrous epidermis. Gall inducer: unknown. Parasitoids/Inquilines: unknown. Plant description: Shrub, nearly $1.5 \mathrm{~m}$ tall, procumbent branches, reddish petioles, and barren. Location: Guanacaste, Liberia, Mayorga. Guanacaste Conservation Area, Góngora, road to the Cacao Volcano, side the road, next to the Góngora River. Coordinates/Altitude: 10,83422222 N 85,6115 W, 569 m. Registry comments: First gall morphotype record for Guanacaste Conservation Area, Costa Rica, and the world.

\section{Picraminiaceae}

Picramnia antidesma Sw. Morphotype Pi_an_1 (Figure 6P). Gall description: Fusiform shape, brown, induced on leaves, lignified epidermis. Gall inducer: unknown. Parasitoids/Inquilines: unknown. Plant description: Shrub, barren. Alternate leaves, with entire margin. Location: Guanacaste, Liberia, Nacascolo. Entrance to the old forest (Bosque Viejo), between the welcome booth and La Casona at Santa Rosa National Park. Coordinates/Altitude: 10,85072 N 85,60796 W, 321 m. Registry comments: First gall morphotype record for Guanacaste Conservation Area, Costa Rica, and the world.

Picramnia antidesma Sw. Morphotype Pi_an_2 (Figure 7A). Gall description: Globular shape, brown, induced on stem, lignified epidermis. Gall inducer: unknown. Parasitoids/Inquilines: unknown. Plant description: Shrub, barren. Alternate leaves, with entire margin. Location: Guanacaste, Liberia, Nacascolo. Santa Rosa National Park, Bosque Viejo area between the park entrance and La Casona Coordinates/Altitude: 10,85072 N 85,60796 W, $321 \mathrm{~m}$. Registry comments: First gall morphotype record for Guanacaste Conservation Area, Costa Rica, and the world.

\section{Piperaceae}

Piper sp. L. Morphotype Pi_sp_1 (Figure 7B). Gall description: Spherical shape, green and yellowish on the surface, whitish pubescence, on petiole and leaf rachis. On abaxial or abaxial leaf position, hairy epidermis. Gall inducer: unknown. Parasitoids/Inquilines: unknown. Plant description: Herbaceous plant, nearly $1 \mathrm{~m}$ tall, by the side of the road. Location: Guanacaste, Liberia, Nacascolo. Entrance to the old forest (Bosque Viejo), between the welcome booth and La Casona at Santa Rosa National Park. Coordinates/Altitude: 10,85072 N 85,60796 W, $321 \mathrm{~m}$. Registry comments: Gall morphotype resembles the one described by Maia \& Mascarenhas (2017) on P. richardiifolium.

Piper sp. L. Morphotype Pi_sp_2 (Figure 7C). Gall description: Spherical shape, green and yellow, induced on Petiole, hairy epidermis. Gall inducer: unknown. Parasitoids/Inquilines: unknown. Plant description: Herbaceous plant, nearly $1 \mathrm{~m}$ tall, by the side of the road. Location: Guanacaste, Liberia, Nacascolo. Entrance to the old forest (Bosque Viejo), between the welcome booth and La Casona at Santa Rosa National Park. Coordinates/Altitude: 10,85072 N 85,60796 W, 321 m. Registry comments: Gall morphotype resembles the one described by Bergamini et al. (2017) on Piper arboreum Aubl.

Piper yucatanense C. DC. Morphotype Pi_yu_1 (Figure 7D). Gall description: Globular shape, green, induced on leaves, glabrous epidermis. Gall inducer: unknown. Parasitoids/Inquilines: unknown. Plant description: Herbaceous plant, nearly $1 \mathrm{~m}$ tall, barren. Location: Guanacaste, Liberia, Mayorga. Guanacaste Conservation Area, Cacao Volcano Sector, pasture area next to the forest, start of the trail to the biological station. Coordinates/Altitude: 10,92286111 N 85,46375 W, $1018 \mathrm{~m}$. Registry comments: First gall morphotype record for Guanacaste Conservation Area, Costa Rica, and the world.

\section{Poaceae}

Paspalum sp. L. Morphotype Pa_sp_1 (Figure 7E). Gall description: Globular shape, brown, on the inflorescense, glabrous epidermis. Gall inducer: unknown. Parasitoids/Inquilines: unknown. Plant description: Herbaceous plants, nearly $50 \mathrm{~cm}$ tall, by the side of the road, purple glumes. Location: Guanacaste, Liberia, Nacascolo. Santa Rosa National Park, between the Inter-American highway and La Casona, secondary oak forest area. Coordinates/Altitude: 10,86577222 N 85,60990278 W, 290 m. Registry comments: First gall morphotype record for Guanacaste Conservation Area, Costa Rica, and the world.

\section{Polygonaceae}

Coccoloba tuerckheimii Donn. Sm. Morphotype Co_tu_1 (Figure 7F). Gall description: Globular shape, orange and brown, induced on on the underside of the leaf, hairy epidermis. Gall inducer: unknown. Parasitoids/Inquilines: unknown. Plant description: Shrub, nearly $3 \mathrm{~m}$ tall, spiral leaves at the end of the branch, barren. Location: Guanacaste, Liberia, Mayorga. Guanacaste Conservation Area, Góngora, road to the Cacao Volcano, secondary forest area, next to the road. Coordinates/ Altitude: 10,89222222 N 85,47077778 W, $701 \mathrm{~m}$. Registry comments: First gall morphotype record for Guanacaste Conservation Area, Costa Rica, and the world, although a gall induced on this plant species was reported, without a reference image, by Ley-López et al. 2019.

Coccoloba venosa L. Morphotype Co_ve_1 (Figure 7G). Gall description: Cylindrical shape, Yellow/brown, induced on the adaxial and abaxial surface of the leaf, glabrous epidermis. Gall inducer: unknown. Parasitoids/Inquilines: unknown. Plant description: Shrub, nearly $1.5 \mathrm{~m}$ tall, on rocky area, flowers with yellow petals and white 

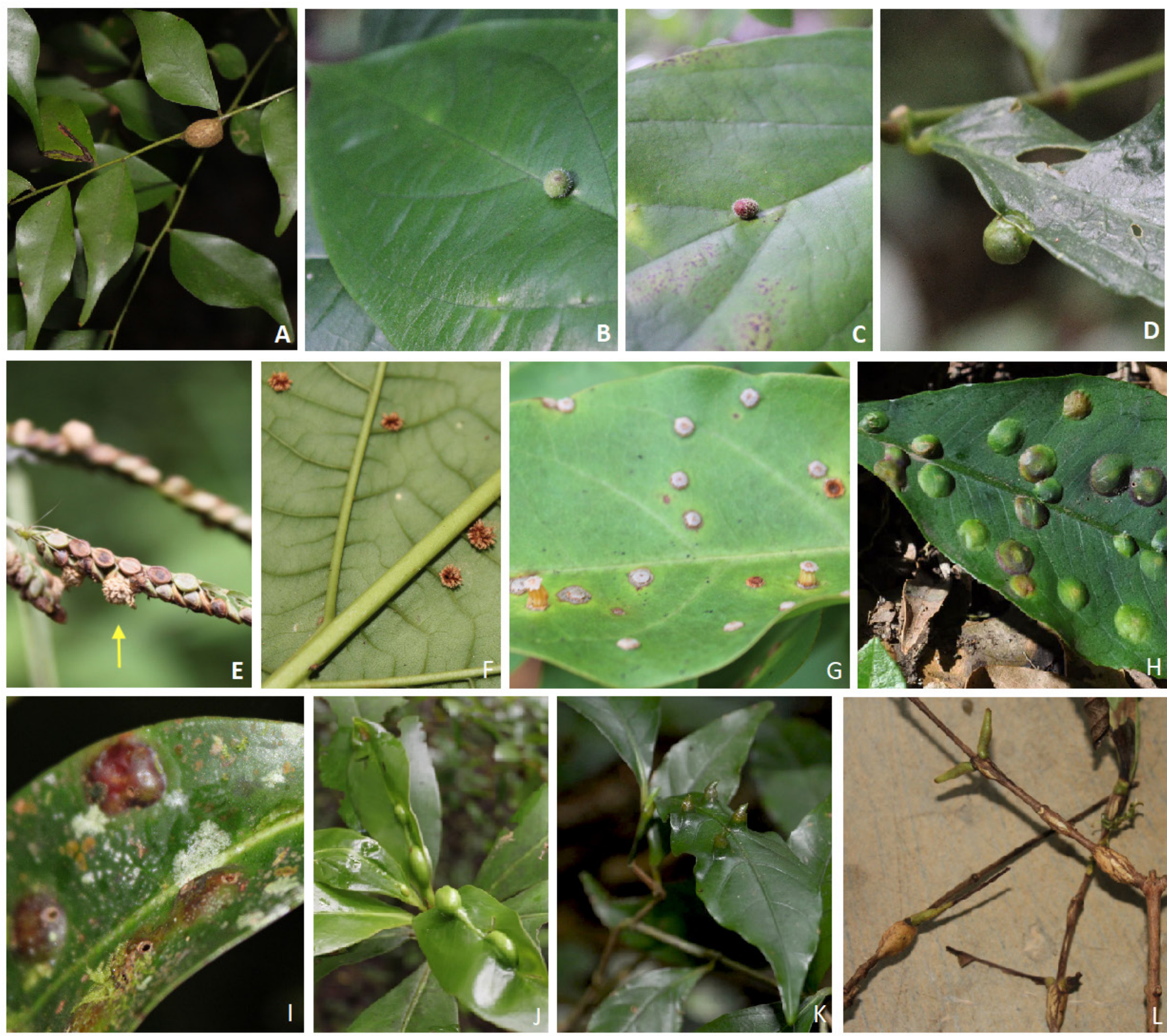

G
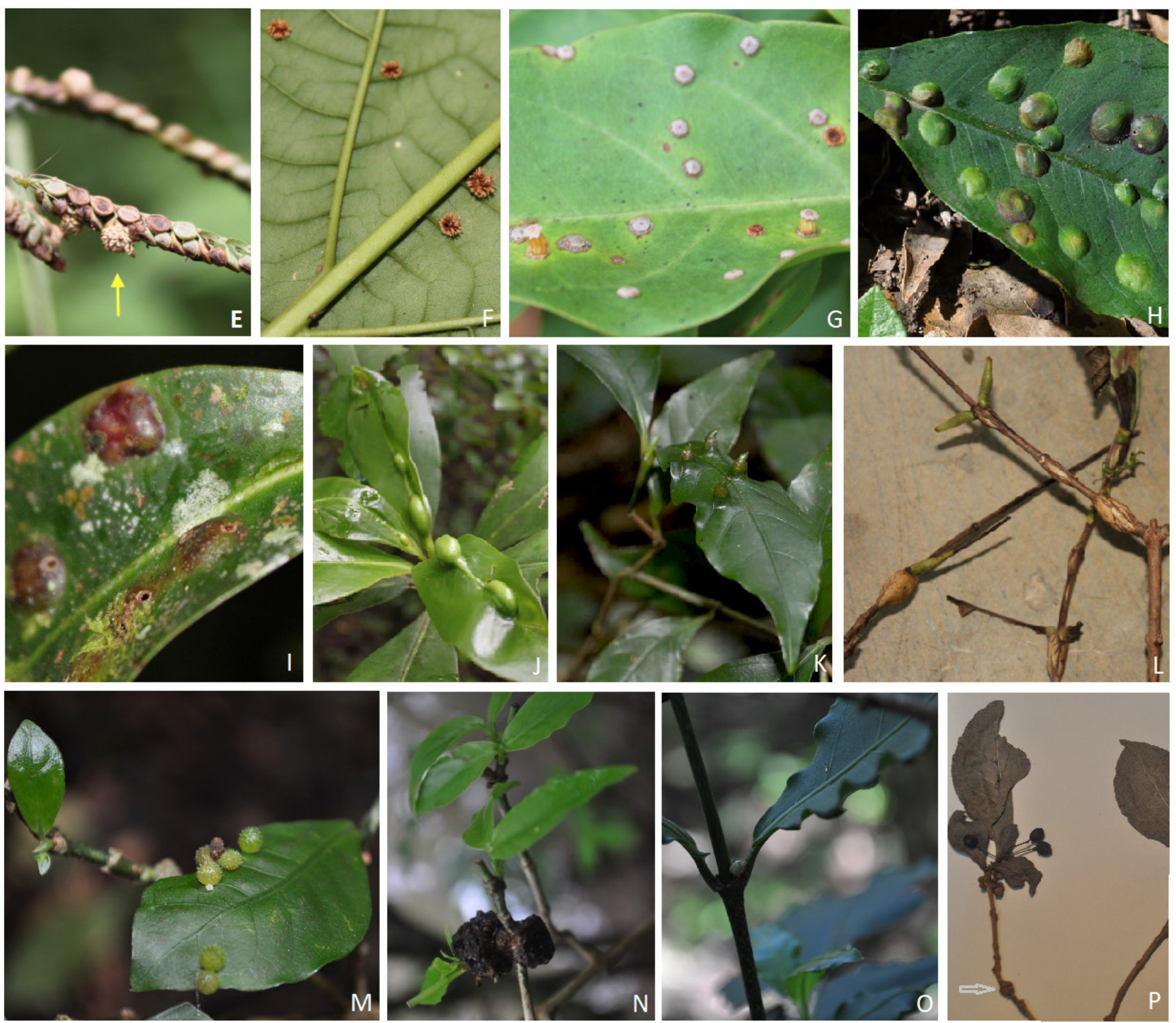

Figure 7. Plant Gall morphotypes recorded in Área de Conservación Guanacaste (ACG), Guanacaste, Costa Rica. 7A) Gall induced in Picramnia antidesma Sw., morphotype Pi_an_2, 7B) Gall induced in Piper sp. L., morphotype Pi_sp_1, 7C) Gall induced in Piper sp. L., morphotype Pi_sp_2, 7D) Gall induced in Piper yucatanense C. DC., morphotype Pi_yu_1, 7E) Gall induced in Paspalum sp. L., morphotype Pa_sp_1, 7F) Gall induced in Coccoloba tuerckheimii Donn. Sm, morphotype Co_tu_1,7G) Gall induced in Coccoloba venosa L., morphotype Co_ve_1,7H) Gall induced in Ardisia compressa Schltdl., morphotype Ar_co_1, 7I) Gall induced in Ardisia compressa Kunth, morphotype Ar_co_2, 7J) Gall induced in Ardisia revoluta Kunth, morphotype Ar_re_1, 7K) Gall induced in Psychotria deflexa DC., morphotype Ps de 1, 7L) Gall induced in Psychotria horizontalis Sw., morphotype Ps ho 1, 7M) Gall induced in Psychotria horizontalis Sw., morphotype Ps_ho_2, 7N) Gall induced in Psychotria horizontalis L., morphotype Ps_ho_3, 7O) Gall induced in Psychotria horizontalis Sw., morphotype Ps_ho_4, 7P) Gall induced in Psychotria quinqueradiata Pol., morphotype Ps_qu_1. 
anthers. Location: Guanacaste, Liberia, Nacascolo. Guanacaste National Park, Santa Rosa Area, old secondary forest area, road to Naranjo Beach. Coordinates/Altitude: 10,79383333 N 85,66 W, 15 m. Registry comments: First gall morphotype record for Guanacaste Conservation Area, Costa Rica, and the world.

\section{Primulaceae}

Ardisia compressa Schltdl. Morphotype Ar_co_1 (Figure 7H). Gall description: Discoid shape, green, induced on leaves, glabrous epidermis. Gall inducer: unknown. Parasitoids/Inquilines: unknown. Plant description: Small tree, $2 \mathrm{~m}$ tall, barren. Location: Guanacaste, Liberia, Curubandé. Guanacaste National Park, Las Pailas Sector, in the forest after the pasture, on the way to the crater. Coordinates/ Altitude: 10,78427778 N 85,3484167 W, 955 m. Registry comments: First gall morphotype record for Guanacaste Conservation Area, Costa Rica, and the world.

Ardisia compressa Kunth. Morphotype Ar_co_2 (Figure 7I). Gall description: Discoid shape, green, brown, and red at maturity, induced on leaves, glabrous epidermis. Gall inducer: unknown. Parasitoids/ Inquilines: Torymus (Torymidae). Plant description: Small tree, $2 \mathrm{~m}$ tall, barren. Location: Guanacaste, Liberia, Mayorga. Guanacaste Conservation Area, Cacao Volcano Sector, Cacao mountain range. Coordinates/Altitude: 10,93202778 N 85,46 W, $1421 \mathrm{~m}$. Registry comments: First gall morphotype record for Guanacaste Conservation Area, Costa Rica, and the world.

Ardisia revoluta Kunth. Morphotype Ar_re_1 (Figure 7J). Gall description: Fusiform shape, green, induced on leaf midvein, glabrous epidermis. Gall inducer: unknown. Parasitoids/Inquilines: unknown. Plant description: Small tree, nearly $4 \mathrm{~m}$ tall, barren. Location: Guanacaste, Liberia, Nacascolo. Santa Rosa National Park, Bosque Viejo area between the entrance of the park and La Casona. Coordinates/ Altitude: 10,85072 N 85,60796 W, 321 m. Registry comments: First gall morphotype record for Guanacaste Conservation Area, Costa Rica, and the world.

\section{Rubiaceae}

Psychotria deflexa DC. Morphotype Ps_de_1 (Figure 7K). Gall description: Conical shape, green and yellow, induced on leaves, glabrous epidermis. Gall inducer: unknown. Parasitoids/Inquilines: unknown. Plant description: Shrub, nearly $1 \mathrm{~m}$ tall, barren. Location: Guanacaste, Liberia, Curubandé. Guanacaste National Park, Las Pailas Sector, in the old secondary forest after the pasture, on the way to the crater. Coordinates/Altitude: 10,78427778 N 85,3484167 W, 955 m. Registry comments: First gall morphotype record for Guanacaste Conservation Area, Costa Rica, and the world.

Psychotria horizontalis Sw. Morphotype Ps_ho_1 (Figure 7L). Gall description: Fusiform shape, brown, induced on stem, lignified epidermis. Gall inducer: unknown. Parasitoids/Inquilines: unknown. Plant description: Herbaceous plant, nearly $50 \mathrm{~cm}$ tall, by the side of the road, greenish unripe fruits. Location: Guanacaste, Liberia, Nacascolo. Santa Rosa National Park, between the Inter-American highway and La Casona, secondary oak forest area. Coordinates/ Altitude: 10,86577222 N 85,60990278 W, 290 m. Registry comments: Gall morphotype resembles the one described by Bergamini et al. (2017) on a Rubiaceae sp.

https://doi.org/10.1590/1676-0611-BN-2020-1153
Psychotria horizontalis Sw. Morphotype Ps_ho_2 (Figure 7M). Gall description: Spherical shape, green, induced on leaves, presence of trichomes epidermis. Gall inducer: unknown. Parasitoids/Inquilines: unknown. Plant description: Herbaceous plant, nearly $50 \mathrm{~cm}$ tall, by the side of the road, greenish unripe fruits. Location: Guanacaste, Liberia, Curubandé. Guanacaste National Park, Las Pailas Sector, in the old secondary forest after the pasture, on the way to the crater. Coordinates/ Altitude: 10,78427778 N 85,3484167 W, 955 m. Registry comments: First gall morphotype record for Guanacaste Conservation Area, Costa Rica, and the world.

Psychotria horizontalis Sw. Morphotype Ps_ho_3 (Figure 7N). Gall description: Globular shape, brown, induced on stem, corrugated and lignified epidermis. Gall inducer: unknown. Parasitoids/Inquilines: unknown. Plant description: Small tree, nearly $1.5 \mathrm{~m}$ tall, barren. Location: Guanacaste, LaCruz. Parque Nacional Guanacaste, on the way to the Maritza Biological Station, secondary growth area along the river. Coordinates/Altitude: 10,95072222 N 85,59705556 W, 272 m. Registry comments: First gall morphotype record for Guanacaste Conservation Area, Costa Rica, and the world.

Psychotria horizontalis Sw. Morphotype Ps_ho_4 (Figure 7O). Gall description: Globular shape, green, induced on petiole, glabrous epidermis. Gall inducer: unknown. Parasitoids/Inquilines: unknown. Plant description: Small tree, nearly $2.5 \mathrm{~m}$ tall, barren. Location: Guanacaste, Liberia, Curubandé. Guanacaste National Park, Las Pailas Sector, in the old secondary forest after the pasture, on the way to the crater. Coordinates/Altitude: 10,76955556 N 85,34519444 W, 744m. Registry comments: First gall morphotype record for Guanacaste Conservation Area, Costa Rica, and the world.

Psychotria quinqueradiata Pol. Morphotype Ps_qu_1 (Figure 7P). Gall description: Fusiform shape, brown, induced on stem, glabrous epidermis. Gall inducer: unknown. Parasitoids/Inquilines: unknown. Plant description: Shrub, nearly $1 \mathrm{~m}$, greenish fruits Location: Guanacaste, Liberia, Curubandé. Guanacaste National Park, Las Pailas Sector, in the old secondary forest after the pasture, on the way to the crater. Coordinates/Altitude: 10,78427778 N 85,3484167 W, 955 m. Registry comments: First gall morphotype record for Guanacaste Conservation Area, Costa Rica, and the world.

Psychotria valerioana Standl. Morphotype Ps_va_1 (Figure 8A). Gall description: Globular shape, green, induced on leaves and buds, glabrous epidermis. Gall inducer: Cecidomyiidae. Parasitoids/ Inquilines: Entedoninae (Eulophidae). Plant description: Shrub, nearly $1 \mathrm{~m}$ tall, greenish fruit, white flowers. Location: Guanacaste, Liberia, Curubandé. Guanacaste National Park, Las Pailas Sector, in the old secondary forest after the pasture, on the way to the crater. Coordinates/ Altitude: 10,78427778 N 85,3484167 W, 955 m; 10,80669 N 85,35 W, 1074 m; 10,80032 N 85,35 W, 1000 m. Registry comments: First gall morphotype record for Guanacaste Conservation Area, Costa Rica, and the world.

Psychotria valerioana Standl. Morphotype Ps_va_2 (Figure 8B). Gall description: Conical shape, green on the base and the apex, yellowish in the middle, induced on leaves, glabrous epidermis. Gall inducer: unknown. Parasitoids/Inquilines: unknown. Plant description: Shrub, nearly $1 \mathrm{~m}$ tall, greenish fruit, white flowers. Location: Guanacaste, Liberia, Curubandé. Rincón de la Vieja National Park, road to active crater, Los gemelos Sector, forest zone. Coordinates/Altitude: 10,80669 N 85,35 W, 1074 m; 10,92286111 N 85,46375 W, 1018 m. 
Gätjens-Boniche O. et al.
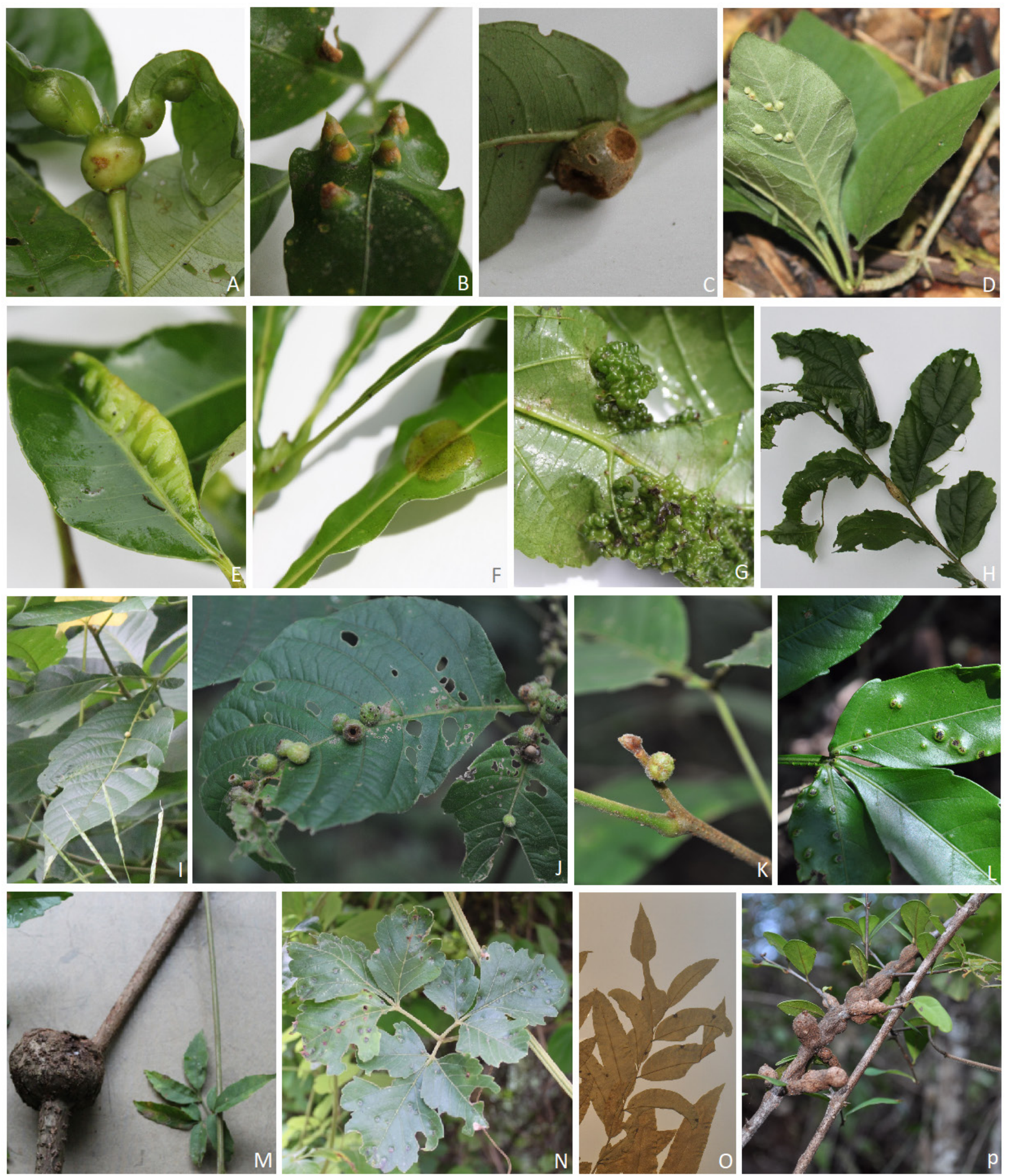

Figure 8. Plant Gall morphotypes recorded in Área de Conservación Guanacaste (ACG), Guanacaste, Costa Rica. 8A) Gall induced in Psychotria valerioana Standl., morphotype Ps_va_1, 8B) Gall induced in Psychotria valerioana Standl., morphotype Ps_va_2, 8C) Gall induced in Psychotria valerioana Standl., morphotype Ps_va_3, 8D) Gall induced in Randia monantha Benth., morphotype Ra_mo_1, 8E) Gall induced in Zanthoxylum sp. L., morphotype Za_sp_1, 8F) Gall induced in Méliosma glabrata (Liebm.) Urb., morphotype Me_gl_1, 8G) Gall induced in Casearia arguta Kunth, morphotype Ca_ar_1, 8H) Gall induced in Casearia arguta Kunth, morphotype $\mathrm{Ca}$ ar 2, 8I) Gall induced in Allophylus racemosus (Sw.), morphotype Al ra 1, 8J) Gall induced in Allophylus racemosus (Sw), morphotype Al_ra_2, 8K) Gall induced in Allophylus racemosus (Sw), morphotype Al_ra_3, 8L) Gall induced in Paullinia cururu L., morphotype Pa_cu_1, 8M) Gall induced in Serjania pyramidata Radlk., morphotype Se_py_1,8N) Gall induced in Serjania schiedeana Schltdl., morphotype Se_sc_1,80) Gall induced in Thouinidium decandrum (Hump \& Band), morphotype Th_de_1, 8P) Gall induced in Sideroxylon obtusifolium (Roem \& Schult), morphotype Si_ob_1. 
Registry comments: First gall morphotype record for Guanacaste Conservation Area, Costa Rica, and the world.

Psychotria valerioana Standl. Morphotype Ps_va_3 (Figure 8C). Gall description: Globular shape, greenish and brown, induced on leaf midvein, glabrous epidermis. Gall inducer: unknown. Parasitoids/ Inquilines: unknown. Plant description: Shrub, nearly $1 \mathrm{~m}$ tall, greenish fruit, white flowers. Location: Guanacaste, Liberia, Mayorga. Guanacaste Conservation Area, Cacao Volcano Sector, pasture area next to the forest and start of the trail to the biological station. Coordinates/ Altitude: 10,92286111 N 85,46375 W, 1018 m. Registry comments: First gall morphotype record for Guanacaste Conservation Area, Costa Rica, and the world.

Randia monantha Benth. Morphotype Ra_mo_1 (Figure 8D). Gall description: Irregular shape, yellowish green (concolorous) on the surface, pale green on the underside, near veins on the underside, protruding from the abaxial surface, hairy epidermis. Gall inducer: unknown. Parasitoids/ Inquilines: unknown. Plant description: Small tree, nearly $6 \mathrm{~m}$ tall, barren. Location: Guanacaste, Liberia, Nacascolo. Entrance to the old forest (Bosque Viejo), between the welcome booth and La Casona at Santa Rosa National Park. Coordinates/Altitude: 10,85072 N 85,60796 W, 321 m; 10,83581 N 85,62347 W, 306 m; 10,83382 N 85,61269 W, 307 m. Registry comments: First gall morphotype record for Guanacaste Conservation Area, Costa Rica, and the world.

\section{Rutaceae}

Zanthoxylum sp. L. Morphotype Za_sp_1 (Figure 8E). Gall description: Irregular shape, green and yellow, induced on leaves, bulging on the leaf border, glabrous epidermis. Gall inducer: unknown. Parasitoids/Inquilines: unknown. Plant description: Tree, nearly $3 \mathrm{~m}$ tall, barren, and fallen. Location: Guanacaste, Liberia, Curubandé. Rincón de la Vieja National Park, road to active crater, Los Gemelos Sector, forest zone. Coordinates/Altitude: 10,80032 N 85,35 W, 1000 $\mathrm{m}$. Registry comments: First gall morphotype record for Guanacaste Conservation Area, Costa Rica, and the world.

\section{Sabiaceae}

Meliosma glabrata (Liebm.) Urb. Morphotype Me_gl_1 (Figure 8F). Gall description: Discoid shape, green and yellow, induced on leaves, sometimes with black dots, rough, on both the surfaces of the leaves, glabrous epidermis. Gall inducer: unknown. Parasitoids/Inquilines: unknown. Plant description: Sapling, nearly $1.5 \mathrm{~m}$ tall, barren. Oblong shaped leaves, with cuspidate apex. Location: Guanacaste, Liberia, Curubandé. Rincón de la Vieja National Park, road to active crater, Los gemelos Sector, forest zone. Coordinates/Altitude: 10,80032 N 85,35 W, 1000 m. Registry comments: First gall morphotype record for Guanacaste Conservation Area, Costa Rica, and the world, although a gall on this plant species was reported, without a reference image, by Ley-López et al. (2019).

\section{Salicaceae}

Casearia arguta Kunth. Morphotype Ca_ar_1 (Figure 8G). Gall description: Irregular shape, green, induced on leaves, glabrous epidermis. Gall inducer: unknown. Parasitoids/Inquilines: Entedoninae (Eulophidae). Plant description: Sapling, nearly $4 \mathrm{~m}$ tall, barren.
Alternate, simple leaves, with crenate margin. Location: Guanacaste, Liberia, Curubandé. Rincón de la Vieja National Park, road to active crater, Los Gemelos Sector, forest zone. Coordinates/Altitude: 10,80669 N 85,35 W, 1074 m; 10,92286111 N 85,46375 W, 1018 m. Registry comments: First gall morphotype record for Guanacaste Conservation Area, Costa Rica, and the world.

Casearia arguta Kunth. Morphotype Ca_ar_2 (Figure 8H). Gall description: Elliptical shape, light brown mixed with green, induced on stem, lignified epidermis. Gall inducer: unknown. Parasitoids/Inquilines: Entedoninae (Eulophidae). Plant description: Sapling, nearly $4 \mathrm{~m}$ tall, barren. Alternate, simple leaves, with crenate margin. Location: Guanacaste, Liberia, Curubandé. Rincón de la Vieja National Park, road to active crater, Los Gemelos Sector, forest zone. Coordinates/Altitude: 10,80669 N 85,35 W, 1074 m. Registry comments: First gall morphotype record for Guanacaste Conservation Area, Costa Rica, and the world.

\section{Sapindaceae}

Allophylus racemosus Sw. Morphotype Al_ra_1 (Figure 8I). Gall description: Globular shape, green-white, induced on leaves, hairy epidermis. Gall inducer: Cecidomyiidae. Parasitoids/Inquilines: unknown. Plant description: Small tree, nearly $4 \mathrm{~m}$ tall, barren. Location: Guanacaste, La Cruz, Santa Elena. Guanacaste Conservation Area, Murciélago Sector, old secondary growth, road between El Hachal bay and Murciélago Station. Coordinates/Altitude: 10,92638889 N 85,7292 W, 45 m. Registry comments: First gall morphotype record for Guanacaste Conservation Area, Costa Rica, and the world.

Allophylus racemosus Sw. Morphotype Al_ra_2 (Figure 8J). Gall description: Spherical shape, green or yellowish, induced on leaf midvein and petiole, hairy epidermis. Gall inducer: unknown. Parasitoids/Inquilines: unknown. Plant description: Shrub, nearly 2.5 $\mathrm{m}$ tall, barren. Location: Guanacaste, La Cruz, La Cruz. Guanacaste National Park, on the way to the Maritza Biological Station, secondary growth area along the river. Coordinates/Altitude: $10,95072222 \mathrm{~N}$ 85,59705556 W, 272 m. Registry comments: First gall morphotype record for Guanacaste Conservation Area, Costa Rica, and the world.

Allophylus racemosus Sw. Morphotype Al_ra_3 (Figure 8K). Gall description: Globular shape, green and yellowish, induced on petiole, hairy epidermis. Gall inducer: unknown. Parasitoids/Inquilines: unknown. Plant description: Shrub, nearly $4 \mathrm{~m}$ tall, barren. Location: Guanacaste, La Cruz, La Cruz. Guanacaste National Park, on the way to the Maritza Biological Station, secondary growth area along the river. Coordinates/Altitude: 10,95072222 N 85,59705556 W, 272 m. Registry comments: First gall morphotype record for Guanacaste Conservation Area, Costa Rica, and the world.

Paullinia cururu L. Morphotype Pa_cu_1 (Figure 8L). Gall description: Discoid shape, green-yellowish and brown, induced on leaves, glabrous epidermis. Gall inducer: unknown. Parasitoids/ Inquilines: unknown. Plant description: Understory, scandent, herbaceous plant, nearly $3 \mathrm{~m}$ tall. Location: Guanacaste, Liberia, Curubandé. Guanacaste National Park, Las Pailas Sector, in the forest after the fumaroles. Coordinates/Altitude: 10,76955556 N 85,34519444 W, $744 \mathrm{~m}$. Registry comments: First gall morphotype record for Guanacaste Conservation Area, Costa Rica, and the world, although a gall on this plant species was reported, without a reference image, by Cuevas et al. (2014). 
Serjania pyramidata Radlk. Morphotype Se_py_1 (Figure 8M). Gall description: Globular shape, brown, induced on stem, lignified epidermis. Gall inducer: unknown. Parasitoids/Inquilines: unknown. Plant description: Vine, barren. Location: Guanacaste, Liberia, Nacascolo. Santa Rosa National Park, between the Inter-American highway and La Casona, secondary oak forest area. Coordinates/Altitude: 10,86577222 N 85,60990278 W, 290 m. Registry comments: First gall morphotype record for Guanacaste Conservation Area, Costa Rica, and the world.

Serjania schiedeana Schltdl. Morphotype Se_sc_1 (Figure 8N). Gall description: Discoid shape, yellow or brown, induced on leaves, glabrous epidermis. Gall inducer: unknown. Parasitoids/Inquilines: unknown. Plant description: Sapling, nearly $25 \mathrm{~cm}$ tall, barren. Rhomboid shaped leaves, with cuspidate apex and denticulate margin, trifoliate/ternate leaves. Location: Guanacaste, Liberia, Nacascolo. Santa Rosa National Park, next to the research laboratories, old secondary forest area. Coordinates/Altitude: 10,83926 N 85,61808 W, 310 m. Registry comments: First gall morphotype record for Guanacaste Conservation Area, Costa Rica, and the world.

Thouinidium decandrum Hump \& Band. Morphotype Th_de_1 (Figure 8O). Gall description: Discoid shape, green to black, induced on leaves, glabrous epidermis. Gall inducer: unknown. Parasitoids/Inquilines: unknown. Plant description: Small tree, nearly $3 \mathrm{~m}$ tall, barren. Imparipinnate, alternate, compound leaves, with slightly serrate margin. Location: Guanacaste, Liberia, Nacascolo. Guanacaste National Park, Naranjo Beach Area, mangrove and beach area, coastal area at dry-forest. Coordinates/Altitude: $10,77928 \mathrm{~N}$ 85,6654 W, 14 m. Registry comments: First gall morphotype record for Guanacaste Conservation Area, Costa Rica, and the world.

\section{Sapotaceae}

Sideroxylon obtusifolium (Humb. ex Roem. \& Schult.) T.D. Penn. Morphotype Si_ob_1 (Figure 8P). Gall description: Fusiform shape, brown, induced on stem, lignified epidermis. Gall inducer: Cecidomyiidae. Parasitoids/Inquilines: unknown. Plant description: Small tree, nearly $3 \mathrm{~m}$ tall, simple axillary white flowers, unripe fruits (green). Location: Guanacaste, La Cruz, Santa Elena. Guancaste National Park, Murciélago Sector, old secondary forest area, on serpentinized peridotite on the edge of the Murciélago River. Coordinates/Altitude: 10,89686111 N 85,7301111 W, 126 m. Registry comments: First gall morphotype record for Guanacaste Conservation Area, Costa Rica, and the world.

Sideroxylon obtusifolium (Humb. ex Roem. \& Schult.) T.D. Penn. Morphotype Si_ob_2 (Figure 9A). Gall description: Irregular shape, green, induced on leaves (midvein), glabrous epidermis. Gall inducer: unknown. Parasitoids/Inquilines: unknown. Plant description: Small tree, nearly $3 \mathrm{~m}$ tall, simple axillary white flowers, unripe fruits (green). Location: Guanacaste, La Cruz, Santa Elena. Guanacaste National Park, Murciélago Sector, old secondary forest area, on serpentinized peridotite on the edge of the Murciélago River. Coordinates/Altitude: 10,89686111 N 85,7301111 W, 126 m. Registry comments: First gall morphotype record for Guanacaste Conservation Area, Costa Rica, and the world.

Sideroxylon obtusifolium (Humb. ex Roem. \& Schult.) T.D. Penn. Morphotype Si_ob_3 (Figure 9B). Gall description: Conical shape, green and yellowish, induced on fruit, glabrous epidermis. Gall inducer: unknown. Parasitoids/Inquilines: unknown. Plant description: Small tree, nearly $3 \mathrm{~m}$ tall, simple axillary white flowers, unripe fruits (green).
Location: Guanacaste, La Cruz, Santa Elena. Guancaste National Park, Murciélago Sector, old secondary forest area, on serpentinized peridotite on the edge of the Murciélago River. Coordinates/Altitude: 10,89686111 N 85,7301111 W, 126 m. Registry comments: First gall morphotype record for Guanacaste Conservation Area, Costa Rica, and the world.

Sideroxylon obtusifolium (Humb. ex Roem. \& Schult.) T.D. Penn. Morphotype Si_ob_4 (Figure 9C). Gall description: Elliptical shape, brown and yellow-green, induced on stem, bulging galls on thorns, lignified epidermis. Gall inducer: unknown. Parasitoids/Inquilines: Cecidellis (Pteromalidae). Plant description: Small tree, nearly $3 \mathrm{~m}$ tall, simple axillary white flowers, unripe fruits (green). Location: Guanacaste, La Cruz, Santa Elena. Guancaste National Park, Murciélago Sector, old secondary forest area, on serpentinized peridotite on the edge of the Murciélago River. Coordinates/Altitude: 10,89686111 N 85,7301111 W, 126 m. Registry comments: First gall morphotype record for Guanacaste Conservation Area, Costa Rica, and the world.

Sideroxylon obtusifolium (Humb. ex Roem. \& Schult.) T.D. Penn. Morphotype Si_ob_5 (Figure 9D). Gall description: Globular shape, green, induced on inflorescence, glabrous epidermis. Gall inducer: unknown. Parasitoids/Inquilines: unknown. Plant description: Small tree, nearly $3 \mathrm{~m}$ tall, simple axillary white flowers, unripe fruits (green). Location: Guanacaste, La Cruz, Santa Elena. Guancaste National Park, Murciélago Sector, old secondary forest area, on serpentinized peridotite on the edge of the Murciélago River. Coordinates/Altitude: 10,89686111 N 85,7301111 W, 126 m. Registry comments: Gall morphotype resembles the one described by Rodrigues et al. (2014).

\section{Simaroubaceae}

Simarouba glauca DC. Morphotype Si_gl_1 (Figure 9E). Gall description: Irregular shape, green and yellowish, induced on leaves (foliar midrib), glabrous epidermis. Sometimes twisting the leaf. Gall inducer: unknown. Parasitoids/Inquilines: unknown. Plant description: Small tree, nearly $4 \mathrm{~m}$ tall, barren. Location: Guanacaste, Liberia, Mayorga. Santa Rosa National Park, lookout point between the main entrance of the park and La Casona. Coordinates/Altitude: 10,85648 N 85,6106 W, $323 \mathrm{~m}$. Registry comments: First gall morphotype record for Guanacaste Conservation Area, Costa Rica, and the world.

\section{Smilacaceae}

Smilax spinosa Mill. Morphotype Sm_sp_1 (Figure 9F). Gall description: Discoid shape, green and yellowish, induced on leaves, glabrous epidermis. Gall inducer: unknown. Parasitoids/Inquilines: Eurytomidae. Plant description: Vine on shrubs, barren. Location: Guanacaste, Liberia, Mayorga. Guanacaste Conservation Area, Cacao Volcano Sector, Cacao Mountain range. Coordinates/Altitude: 10,93202778 N 85,46 W, 1421 m. Registry comments: First gall morphotype record for Guanacaste Conservation Area, Costa Rica, and the world.

\section{Solanaceae}

Lycianthes multiflora. Morphotype Ly_mu_1 (Figure 9G). Gall description: Fusiform shape, brown, induced on leaf veins, glabrous epidermis. Gall inducer: unknown. Parasitoids/Inquilines: unknown. Plant description: Herbaceous vine on shrub. Alternate leaves. Location: 

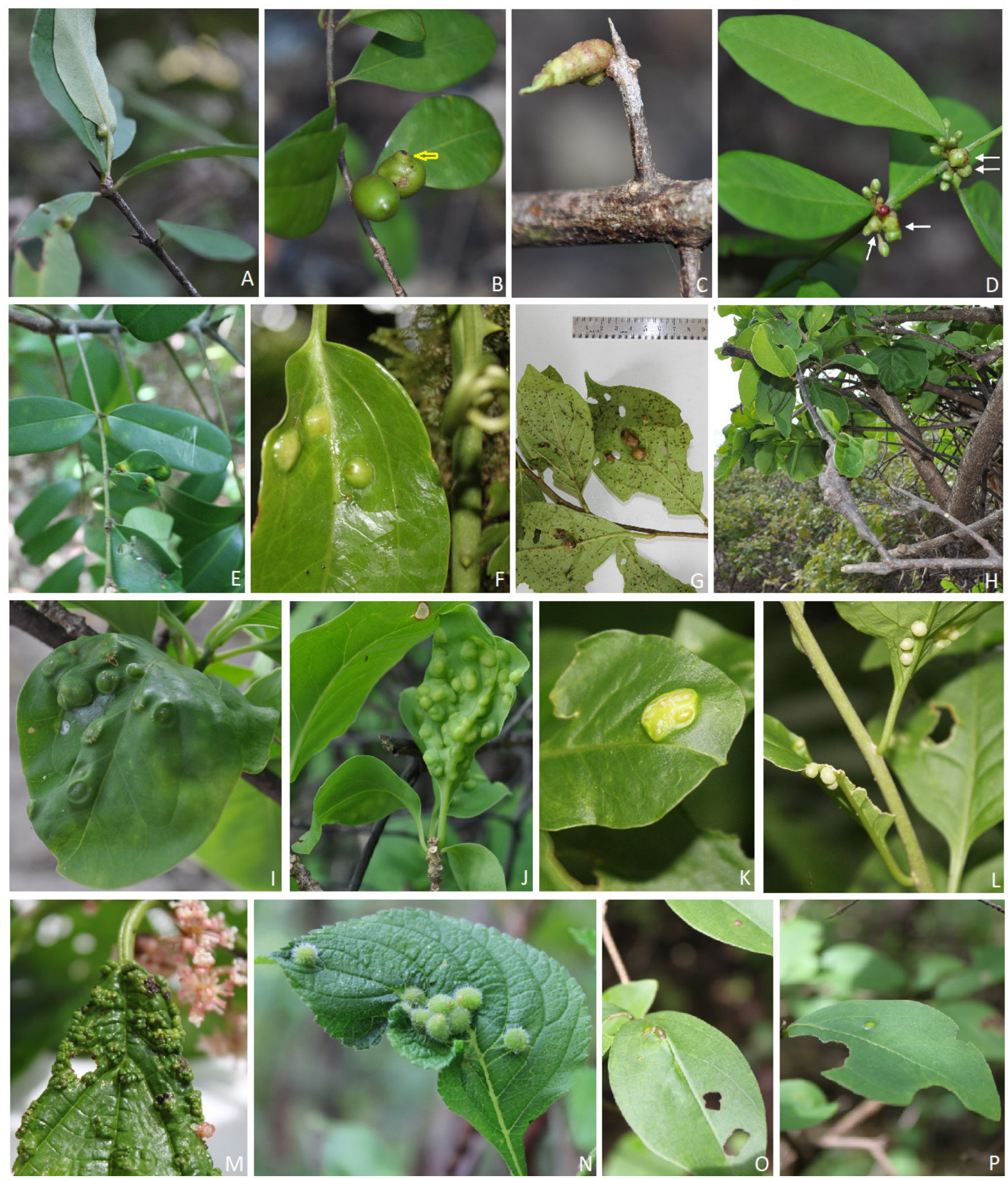

Figure 9. Plant Gall morphotypes recorded in Área de Conservación Guanacaste (ACG), Guanacaste, Costa Rica. 9A) Gall induced in Sideroxylon obtusifolium (Roem \& Schult), morphotype Si_ob_2, 9B) Gall induced in Sideroxylon obtusifolium (Roem \& Schult), morphotype Si_ob_3, 9C) Gall induced in Sideroxylon obtusifolium (Humb. ex Roem. \& Schult.) T.D. Penn., morphotype Si_ob_4, 9D) Gall induced in Sideroxylon obtusifolium (Humb. ex Roem. \& Schult.) T.D. Penn., morphotype Si_ob_5, 9E) Gall induced in Simarouba glauca DC, morphotype Si_gl_1, 9F) Gall induced in Smilax spinosa Mill., morphotype Sm_sp_1, 9G) Gall induced in Lycianthes multiflora, morphotype Ly_mu_1,9H) Gall induced in Stegnosperma cubense A. Rich, morphotype St_cu_1, 9I) Gall induced in Stegnosperma cubense A. Rich, morphotype St cu 2, 9J) Gall induced in Stegnosperma cubense A. Rich, morphotype St cu 3, 9K) Gall induced in Stegnosperma cubense A. Rich, morphotype St_cu_4, 9L) Gall induced in Stegnosperma cubense A. Rich, morphotype St_cu_5, 9M) Gall induced in Urera simplex Wedd., morphotype Ur_si_1,9N) Gall induced in Lippia oxyphyllaria (Donn. Sm.) Standl., morphotype Li_ox_1, 90) Gall induced in Rehdera trinervis (S.F. Blake) Moldenke, morphotype Re_tr_1, 9P) Gall induced in Rehdera trinervis (S.F. Blake) Moldenke, morphotype Re_tr_2. 
Guanacaste, Liberia, Curubandé. Rincón de la Vieja National Park, road to active crater, Los Gemelos Sector, rainforest zone. Coordinates/ Altitude: 10,80032 N 85,35 W, 1000 m. Registry comments: First gall morphotype record for Guanacaste Conservation Area, Costa Rica, and the world, although a gall induced on this plant species was reported, without a reference image, by Ley-López et al. (2019).

\section{Stegnospermataceae}

Stegnosperma cubense A. Rich. Morphotype St_cu_1 (Figure 9H). Gall description: Fusiform shape, grayish, induced on stem, lignified epidermis. Gall inducer: unknown. Parasitoids/Inquilines: unknown. Plant description: Decumbent shrub, nearly $2.5 \mathrm{~m}$ and $1 \mathrm{~m}$ tall, barren. Location: Guanacaste, Liberia, Nacascolo. Guanacaste National Park, Naranjo Beach Area, mangrove and area, coastal area in dry-forest. Coordinates/Altitude: 10,7791389 N 85,66594444 W, 14 m. Registry comments: First gall morphotype record for Guanacaste Conservation Area, Costa Rica, and the world.

Stegnosperma cubense A. Rich. Morphotype St_cu_2 (Figure 9I). Gall description: Discoid shaped galls, green, induced on leaves, glabrous epidermis. Gall inducer: unknown. Parasitoids/Inquilines: Eulophidae. Plant description: Decumbent shrub, nearly $2.5 \mathrm{~m}$ and $1 \mathrm{~m}$ tall, barren. Location: Guanacaste, Liberia, Nacascolo. Guanacaste National Park, Naranjo Beach Area, mangrove and beach area, coastal area in dry-forest. Coordinates/Altitude: 10,77928 N 85,6654 W, 14 m. Registry comments: First gall morphotype record for Guanacaste Conservation Area, Costa Rica, and the world.

Stegnosperma cubense A. Rich. Morphotype St_cu_3 (Figure 9J). Gall description: Globular shape, light green, induced on leaves, glabrous epidermis. Gall inducer: unknown. Parasitoids/Inquilines: unknown. Plant description: Decumbent shrub, nearly $2.5 \mathrm{~m}$ and $1 \mathrm{~m}$ tall, barren. Location: Guanacaste, Liberia, Nacascolo. Guanacaste National Park, Naranjo Beach Area, mangrove and beach area, coastal area in dry-forest. Coordinates/Altitude: 10,7791389 N 85,66594444 W, $14 \mathrm{~m}$. Registry comments: First gall morphotype record for Guanacaste Conservation Area, Costa Rica, and the world.

Stegnosperma cubense A. Rich. Morphotype St_cu_4 (Figure 9K). Gall description: Discoid shape, yellow to greenish, induced on leaves, glabrous epidermis. Gall inducer: unknown. Parasitoids/Inquilines: unknown. Plant description: Decumbent shrub, nearly $2.5 \mathrm{~m}$ and $1 \mathrm{~m}$ tall, barren. Location: Guanacaste, La Cruz, Santa Elena. Guanacaste Conservation Area, Murciélago Sector, old secondary growth, road between El Hachal Bay and Murciélago Station. Coordinates/Altitude: 10,92638889 N 85,7292 W, 45 m. Registry comments: First gall morphotype record for Guanacaste Conservation Area, Costa Rica, and the world.

Stegnosperma cubense A. Rich. Morphotype St_cu_5 (Figure 8L). Gall description: Globular shape, white to greenish, induced on the underside of the leaf, glabrous epidermis. Gall inducer: unknown. Parasitoids/Inquilines: unknown. Plant description: Decumbent shrub, nearly $2.5 \mathrm{~m}$ and $1 \mathrm{~m}$ tall, barren. Prominent globularl galls,. Location: Guanacaste La Cruz, Santa Elena. Guanacaste Conservation Area, Murciélago Sector, old secondary growth, road between El Hachal Bay and Murciélago Station. Coordinates/Altitude: 10,92638889 N 85,7292 W, 45 m. Registry comments: First gall morphotype record for Guanacaste Conservation Area, Costa Rica, and the world.

\section{Urticaceae}

Urera simplex Wedd. Morphotype Ur_si_1 (Figure 9M). Gall description: Irregular shape, green and yellow, induced on leaves, distributed throughout the upper leaf surface and underside, glabrous epidermis. Gall inducer: unknown. Parasitoids/Inquilines: unknown. Plant description: Shrub, nearly $3 \mathrm{~m}$ tall, inflorescence with white stamens, pink petals and pedicels. Location: Guanacaste, Liberia, Curubandé. Rincón de la Vieja National Park, road to active crater, Los gemelos Area, rainforest zone. Coordinates/Altitude: 10,80032 N $85,35 \mathrm{~W}, 1000 \mathrm{~m}$. Registry comments: First gall morphotype record for Guanacaste Conservation Area, Costa Rica, and the world.

\section{Verbenaceae}

Lippia oxyphyllaria (Donn. Sm.) Standl. Morphotype Li_ox_1 (Figure 9N). Gall description: Spherical shape, light green, induced on leaves (midvein or secondary veins), hairy epidermis. Gall inducer: Cecidomyiidae. Parasitoids/Inquilines: unknown. Plant description: Herbaceous plant or shrub, up to $2 \mathrm{~m}$ tall, barren. Location: Guanacaste, Liberia, Nacascolo. Santa Rosa National Park, Santa Rosa Area, between the entrance of the Inter-American highway and La Casona, secondary oak forest area. Coordinates/Altitude: 10,86577222 N 85,60990278 W, 290 m. Registry comments: First gall morphotype record for Guanacaste Conservation Area, Costa Rica, and the world.

Rehdera trinervis (S.F. Blake) Moldenke. Morphotype Re_tr_1 (Figure 9O). Gall description: Elliptical shape, green and brown, induced on leaf midvein, glabrous epidermis. Gall inducer: unknown. Parasitoids/Inquilines: unknown. Plant description: Small woody sapling, nearly $3 \mathrm{~m}$ tall, strong secondary growth. Location: Guanacaste, Liberia, Nacascolo. Santa Rosa National Park between the Inter-American highway and La Casona, secondary oak forest area. Coordinates/Altitude: 10,86577222 N 85,60990278 W, 290 m. Registry comments: First gall morphotype record for Guanacaste Conservation Area, Costa Rica, and the world.

Rehdera trinervis (S.F. Blake) Moldenke. Morphotype Re_tr_2 (Figure 9P). Gall description: Discoid shape, green and yellowish, induced on leaves, glabrous epidermis. Gall inducer: unknown. Parasitoids/Inquilines: unknown. Plant description: Small woody sapling, nearly $3 \mathrm{~m}$ tall, strong secondary growth. Location: Guanacaste, Liberia, Nacascolo. Santa Rosa National Park between the Inter-American highway and La Casona, secondary oak forest area. Coordinates/Altitude: 10,86577222 N 85,60990278 W, 290 m. Registry comments: First gall morphotype record for Guanacaste Conservation Area, Costa Rica, and the world.

\section{Vitaceae}

Cissus fuliginea Croat. Morphotype Ci_fu_1 (Figure 10A). Gall description: Fusiform shape, green to yellowish green, induced on stem and leaf veins, hairy epidermis. Gall inducer: Cecidomyiidae. Parasitoids/Inquilines: unknown. Plant description: Vine, near by the mud pits. Tropical dry forest area. Trifoliate leaves with serrate margin and tendrils. On top of Sweetenia, barren. Location: Guanacaste, Liberia, Nacascolo. Administrative area of the National Park. Coordinates/ Altitude: 10,83694444 N 85,62 W, 406 m; 10,76955556 N 85,34519444 W, $744 \mathrm{~m}$. Registry comments: First gall morphotype record for Guanacaste Conservation Area, Costa Rica, and the world.

https://doi.org/10.1590/1676-0611-BN-2020-1153 

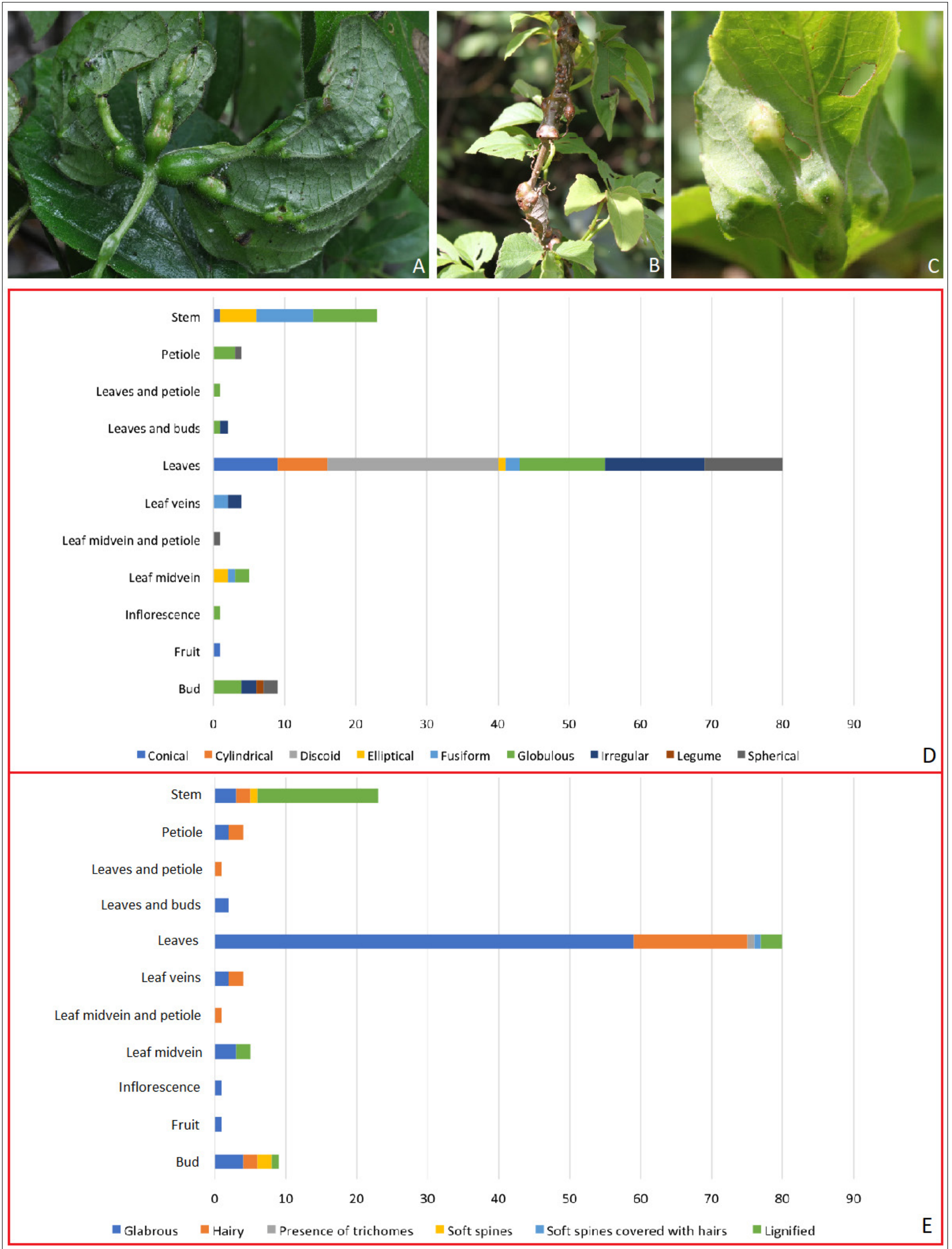

Figure 10. Plant Gall morphotypes recorded in Área de Conservación Guanacaste (ACG), Guanacaste, Costa Rica. 10A) Gall induced in Cissus fuliginea (Croat.), morphotype Ci_fu_1, 10B) Gall induced in Cissus fuliginea (Croat.), morphotype Ci_fu_2, 10C) Gall induced in Cissus fuliginea (Croat.), morphotype Ci_fu_3, 10D) Gall morphology vrs incidence in plant organs, 10E) Gall epidermis texture and their incidence by plant organ. For 10D and $10 \mathrm{E}$, the values on the $\mathrm{X}$-axis represent the total number of morphotypes. 
Cissus fuliginea Croat. Morphotype Ci_fu_2 (Figure 10B). Gall description: Fusiform shape, reddish-brown or green, induced on stem, lignified epidermis. Gall inducer: unknown. Parasitoids/Inquilines: unknown. Plant description: Vine, near by the mud pits. Tropical dry forest area. Trifoliate leaves with serrate margin and tendrils. On top of Sweetenia, barren. Location: Guanacaste, Liberia, Mayorga. Guanacaste Conservation Area, Góngora, road to the Cacao Volcano, sedimentary rock area next to the Góngora River. Coordinates/Altitude: 10,83422222 N 85,6115 W, 569 m; 10,76955556 N 85,34519444 W, 744 m. Registry comments: First gall morphotype record for Guanacaste Conservation Area, Costa Rica, and the world.

Cissus fuliginea Croat. Morphotype Ci_fu_3 (Figure 10C). Gall description: Irregular shape, green to yellowish green, induced on leaf veins, glabrous epidermis. Gall inducer: unknown. Parasitoids/ Inquilines: Tetrastichinae (Eulophidae). Plant description: Vine, near by the mud pits. Tropical dry forest area. Trifoliate leaves with serrate margin and tendrils. On top of Sweetenia, barren, exposed. Location: Guanacaste, Liberia, Nacascolo. Santa Rosa National Park, start of the road to Naranjo Beach, old secondary growth area with clearings. Coordinates/Altitude: 10,83581 N 85,62347 W, 306 m; 10,83422222 N 85,6115 W, 569 m. Registry comments: First gall morphotype record for Guanacaste Conservation Area, Costa Rica, and the world.

From the 131 gall morphotypes recorded, the leaves were the organ with the largest number of galls with sixty-one percent $(n=80)$, followed by stems (17.6\%), and apical buds (6.9\%) (Figure 10D). Eight different morphotype forms of galls were identified: conical, cylindrical, discoid, elliptical, fusiform, globular, irregular, and spherical. The most frequent gall shape was globular (globulous) $(25.2 \%)$, followed by discoid (18.3\%), irregular (14.5\%), spherical (11.5\%) and conical with $8.4 \%$. The greatest number of gall shapes on leaves were discoid $(30 \%)$, followed by irregular (17.5\%), globular (15\%), and spherical (14\%) (Figure 10D). We also described six different types of gall epidermal texture: hairy, presence of trichomes, glabrous, soft spines, soft spines covered with hairs, and lignified. Fifty-nine percent of galls were glabrous, twenty-one percent were hairy and eighteen were lignified, which were among the most abundant. The most common epidermal texture on leaves was glabrous (77\%), as well as hairy about $61 \%$ ). Lignified epidermis (74\% prevalence) was the most frequent texture on stems (Figure 10E). Green was the predominant color of galls, with $27 \%$.

Except for 11 records, 120 of all recorded galls are new records for ACG, Costa Rica and the world. The collected plant gall morphotypes and their associated organisms from the Guanacaste Conservation Area, were characterized and recorded in a biological database within a specialized herbarium. We named this integrated herbarium a cecidiarium.

When we compare trichome-like structures and lignified external texture in the recorded gall morphotypes between the deciduous and evergreen forest (Bosque Viejo), 55\% of the total morphotypes exhibit trichome-like structures and $43.5 \%$ has lignified texture in the evergreen forest. The chi-square test did not show significant statistical differences between the two types of forest for these two phenotypic variables $\left(\mathrm{p}>0.05, \chi_{(\alpha=0,05, d f=l)=}^{2} 3.84\right)$.

\section{Discussion}

A large number of galling insects have been described in recent years and estimates clearly suggest that the number of species yet to be described could significantly exceed the number of known species (Espírito-Santo \& Fernandes 2007). New gall morphotypes have been reported continuously, especially from Brazil, mainly as a consequence of an active community of researchers in that country.

Based on the reviewed literature, it appears that 120 morphotypes described and registered in this study are new records, not only for Costa Rica, but also for the world. Although samples were collected in the rainy season, when plants have a greater amount of green biomass, we estimate that the galls recorded here represent a small portion of the total plant galls present in the Guanacaste Conservation Area. This is based on the higher plant diversity and topographic characteristics of the AGC, as well as the difficulties in searching and obtaining samples from the canopy, particularly in tall trees like those in the Bosque Viejo (old forest). The canopy is the forest stratum with the greatest active growth, and so this is an area where it would be more probable to find galls. Additionally, many galls are hidden inside fruits and other plant organs such as roots (Ley-López et al. 2019), and the high plant density interferes with searching for and finding galls.

Most of the galling species in the Mexican tropical dry forest, for instance, occurred on trees and shrubs, with fewer on herbs and climbing plants (Cuevas-Reyes et al. 2014). For the ACG tropical dry forest, the panorama was similar, based on our results. Moreover, in the tropical dry forest of the Caatinga (Pernambuco, Brazil), most galls were induced on leaves $(73.44 \%)$, stems $(20.31 \%)$, and on apical buds (6.25\%) (Santos et al. 2011b). These results were similar to data obtained for ACG, where $61 \%$ of galls were formed on leaves, followed by stems $(17.6 \%)$, and on apical buds (6.9\%) (Figure 10D). In contrast to the Caatinga, where the most frequent gall shape was spheroid (32.81\%), followed by discoid with $25 \%$ (Santos et al. 2011b), for ACG the most frequent gall shape was globular (25.2\%), but, the percentage of discoid galls was similar with $18.3 \%$ (the second one in frequency). Furthermore, glabrous epidermis shows the highest frequency in both tropical dry forests, with $78 \%$ for the Caatinga and $77 \%$ for the ACG, surprisingly similar values. Additionally, green was the predominant surface color of galls with $27 \%$ for ACG, while it was $73 \%$ for the Caatinga (Santos at al. 2011b). Moreover, as in the ACG, for the tropical dry forest of Parque da Sapucaia-Brazil (Costa \& Araújo 2019), the plant family with the greatest richness of gall morphotypes was Fabaceae. Similarly, the most affected plant organ was the leaf $(82.2 \%)$. Otherwise, globular $(20.6 \%)$ and discoid $(13.7 \%)$ were the most abundant gall shapes in the aforementioned study, which are comparable with the values for ACG (globular 25.2\% and discoid with 18.3\%). Glabrous was the predominant external texture with $82.7 \%$ and green the most frequent gall color $(44.8 \%)$ in the tropical dry forest of Parque da Sapucaia, while in the ACG $59 \%$ of the galls were glabrous and $27 \%$ were green.

The presence of trichomes on gall epidermis ("hairy" or pilose) could be important due to the known properties of these anatomical structures in protecting plants against insect attack (especially the phytophagous insects), temperature regulation, and drought resistance by reducing water loss and moisture retention. Moreover, accumulated evidence suggests that trichomes can absorb UV radiation and reduce the damage by UV-B to photosystem II, preventing stomatal closure (Xiao et al. 2017). Lignins have been associated with plant mechanical support, growth, resistance to insect pests, temperature regulation, and drought tolerance, among other functions (Liu et al.2018). Leaving aside the hypothesis that 
tissue lignification protects the plant against natural enemies, in galls lignification has also been associated with water conduction (Guedes et al. 2019), as well as protection from UV and oxidative damages generated by excess light exposure and water deficiency (Detoni et al. 2011, Arriola et al. 2018). Our data from ACG shows that only $21 \%$ of morphotypes exhibit trichomes on the epidermis while $17.6 \%$ of gall morphotypes were lignified, which represents less than expected according to the adaptive advantages attributed to both phenotypic traits. Nevertheless, the lignified epidermis was the most frequent texture in stem galls with $74 \%$ (Figure 10E). Given the function that both anatomical traits could have as a selective response to abiotic conditions, when we compare the deciduous and evergreen forest (e.g. Bosque Viejo), our results contrast with what might be expected, since in the evergreen forest $55 \%$ of the total morphotypes showed trichome-like structures and $43.5 \%$ of all galls exhibit lignified external texture ( $\mathrm{p}>0.05, \chi_{(\alpha=0,05, d f=1)}{ }^{2}$ $3.84)$. Hence, the values for these two phenotypic variables did not show significant statistical differences between the two types of forest. The role of lignified and trichome-covered galls in different biomes of the tropical dry forest are still open questions that should be studied in greater detail.

The low success rate in obtaining adult gall-inducers from a given sample can be explained by the lack of knowledge of insect and gall phenologies. The most practical way of increasing the success rate of rearing adults is probably by collecting the same gall morphotype throughout the year since many galls are seasonal. Furthermore, multiple samples would be needed from each plant species, a task that is frequently not possible because of the time and resources required.

In recent years new gall morphotypes are being reported continuously (Nieves-Aldrey et al. 2008, Hanson et al. 2014), Goetz et al. 2018, Araújo et al. 2019, Costa \& Araújo 2019). The evidence from these new reports suggests that gall diversity is directly correlated with the richness of plant species in the areas under study (Cuevas-Reyes et al. 2014, Araújo 2017, Coelho et al. 2017). Thus, the previous assumption that gall diversity in tropical regions is less than that in xeric temperate regions is not sustainable considering the biodiversity in tropical ecosystems and the results of the latest studies on the diversity of galls in tropical regions. Cuevas-Reyes et al. (2004) found a significant positive correlation between gallinducing insect species richness and plant species abundance in a Mexican tropical dry forest.

Given the above evidence that future inventories in tropical regions will continue to discover an increasing diversity of gall morphotypes, we proposed organizing the plant galls and associated organisms in a specialized herbarium. This allowed us to have wet and dry collections of plant samples, and preserved specimens of the organisms associated with the galls, in combination with physical records and digital databases providing detailed information about the collected morphotypes, including proper image registration. A detailed repository for the inventory will avoid failures in gall descriptions as well as prevent mixing samples and information from plant galls with other unrelated data. For instance, Ley-López et al. (2019), reported that around $25 \%$ of plant specimens previously recorded with galls in the herbarium were ambiguous as to whether the tissue alteration was a gall or not. The specialized herbarium established as a direct consequence of this research represents a unique kind of biological collection different from a traditional plant herbarium, and for this reason the name cecidiarium was suggested as a general concept for summarizing these types of biological records. Considering the diversity of plant galls, this effort represents an important reservoir of germplasm that should be conserved under proper conditions.

Despite the increasing number of new gall morphotypes being reported, some problems still remain beforeachieving a standardized classification. Problems include poor gall morphotype characterization, lack of referenced photos or poor quality images, and the non-existence of a standardized nomenclature. Here, we propose a standardized codification system for plant gall morphotype classification, with the aim of avoiding confusion in the registry of these structures. Gall morphotypes were named using the two first letters from the binomial scientific name of the host plant, followed by the numerical order in which they were discovered (Figures 2-10).

Detailed maps with geographic coordinates, altitudinal distribution, forest cover, and other data are useful tools for understanding the ecological context of gall occurrence. Therefore, georeferenced maps with an appropriate data will allow us to pinpoint and contrast host plant distribution with insect-inducer distribution and habitat (Figure 11).

\section{Acknowledgments}

The authors thank to Marvin Quesada, Luis Fernando Benavides and Gerald Sanchez for their assistance and technical support, as well as to Gregorio Dauphin for his initial contribution to this research.

\section{Author Contributions}

Omar Gätjens-Boniche: substantial contribution in the concept and design of the study; contribution to data collection; contribution to data analysis and interpretation; contribution to the data registration and processing; obtained the financial support and wrote the article.

Paul Hanson: contribution in the concept and design of the study; contribution to critical revision, adding intellectual content; contribution to manuscript preparation; contribution to identify the inductor and insects associated with plant galls.

Marilyn Sanchez-Valverde: contribution to the data registration and processing; contribution to manuscript preparation.

Carla Trejos-Araya: contribution to data analysis and interpretation; contribution to critical revision; contribution to manuscript preparation.

Roberto Espinoza: substantial contribution in the taxonomic identifications of the host plants.

Adrian Pinto-Tomás: contribution to critical revision, adding intellectual content.

\section{Conflicts of Interest}

The authors declare that they have no conflict of interest related to the publication of this article.

\section{Ethics}

Host plants and their galls were collected under the permission of the Comisión Nacional para la Gestión de la Biodiversidad (CONAGEBIO) of Costa Rica. 


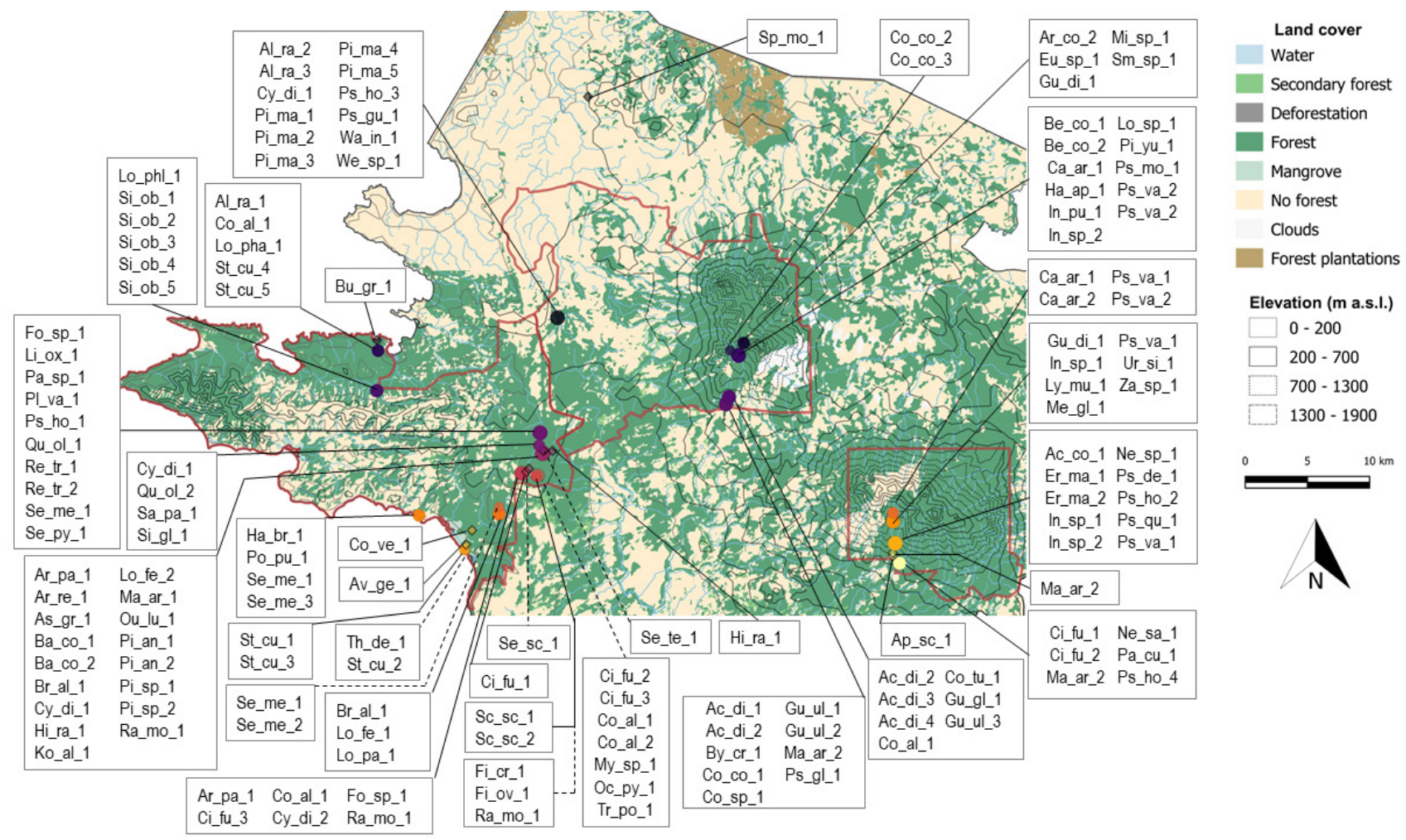

Figure 11. Spatial distribution of gall morphotypes collected in Área de Conservación Guanacaste (ACG), Guanacaste province, northwest region of Costa Rica. Diamond symbols represent sites were only one gall morphotype was collected. Circle symbols represent cluster sites where two or more gall morphotypes were found; circle diameters vary according to the number of gall morphotypes collected in this area. Larger circles mean that more gall morphotypes were found at a specific area. Cluster size varies between 5-400 linear meters.

\section{Funding}

This survey was funded and supported by the Technological Institute of Costa Rica (Instituto Tecnológico de Costa Rica, Vicerrectoría de Investigación y Extensión) by the project number 5402- 2160- 3101.

\section{References}

ABRAHAMSON, W., MELIKA, G., SCRAFFORD, R. \& CSOKA, G. 1998. Gall-inducing insects provide insights into plant systematic relationships. American Journal of Botany 85 (8): 1159. doi: 10.2307/2446348

ANSALONI, L. S., SALMAZO, J. R. \& GUIMARÃES, M. V. U. (2018). Entomogen galls in a Seasonal Semideciduous Forest area in Sorocaba, Southeast of São Paulo State, Brazil. Biota Neotropica, 18(4): e20180523. https://doi.org/10.1590/1676-0611-bn-2018-0523

ARAÚJO, W. 2017. Plant species richness mediates the effects of vegetation structure, but not soil fertility, on insect gall richness in a savanna in Brazil. Journal of Tropical Ecology 33(3): 197-204. doi:10.1017/S0266467417000086

ARAÚJO, W. S. DE, FERNANDES, G. W. \& SANTOS, J. C. 2019. An overview of inventories of gall-inducing insects in Brazil: looking for patterns and identifying knowledge gaps. Anais da Academia Brasileira de Ciências 91(1): e20180162. https://dx.doi.org/10.1590/0001-3765201920180162

ARRIOLA, Í.A., MELO-JÚNIOR, J.C.F., FERREIRA, B.G. \& ISAIAS R.M.S. 2018. Galls on Smilax campestris Griseb. (Smilacaceae) protect the insects against restinga constraints, but do not provide enriched nutrition. Braz. J. Bot. 41: 145-153. https://doi.org/10.1007/s40415-017-0423-y

ASCENDINO, S. \& MAIA, V. C. 2018. Insects galls of Pantanal areas in the State of Mato Grosso do Sul, Brazil: characterization and occurrence. Anais da Academia Brasileira de Ciências 90(2): 1543-1564. https://dx.doi. org/10.1590/0001-3765201820170535

BERGAMINI, B. A. R., BERGAMIN, L. L., SANTOS, B. B. D. \& ARAÚJO, W. S. 2017. Occurrence and characterization of insect galls in the Floresta Nacional de Silvânia, Brazil. Papéis Avulsos de Zoologia 57(32): 413-431. http://dx.doi.org/10.11606/0031-1049.2017.57.32
BORCHERT, R. 1994. Soil and stem water storage determine phenology and distribution of tropical dry forest trees. Ecology 75: 1437-1449.

CARNEIRO M.A.A, BLANCO C.S.A., BRAGA C.D.E., ALMADA E.D., COSTA M.B.M., MAIA V.C. \& FERNANDES G.W. 2009. Are gall midge species (Diptera, Cecidomiiydae) host-plant specialists? Revista Brasileira de Entomologia 53: 365-378.

CARVALHO-FERNANDES, S. P., ASCENDINO, S., MAIA, V. C. \& COURI, M. S. 2016. Diversity of insect galls associated with coastal shrub vegetation in Rio de Janeiro, Brazil. Anais da Academia Brasileira de Ciências 88(3): 1407-1418. https://dx.doi.org/10.1590/0001-3765201620150658

CATIE. N.D. Relieve2008crtm05. Atlas CR 2014. [CD]. ITCR, Cartago.

COELHO, M.S., ALMADA, E. D., FERNANDES, G.W., CARNEIRO, M. A., DOS SANTOS, R. M., QUINTINO, A. V. \& SANCHEZ-AZOFEIFA, A. 2009. Gall inducing arthropods from a seasonally dry tropical forest in Serrá do Cipó, Brazil. Revista Brasileira de Entomologia 53(3): 404-414. http:// dx.doi.org/10.1590/S0085-56262009000300015

COELHO, M. S., ALVES CARNEIRO, M. A., BRANCO, C. A., BORGES, R. A. X. \& FERNANDES G. W. 2017. Galling insects of the Brazilian páramos: Species richness and composition along high-altitude grasslands. Environmental Entomology, 46(6), 1243-1253. doi: 10.1093/ee/nvx147

COSTA, K. C. \& ARAÚJO, W. S. 2019. Distribution of gall-inducing arthropods in areas of deciduous seasonal forest of Parque da Sapucaia (Montes Claros, MG, Brazil): effects of anthropization, vegetation structure and seasonality. Papéis Avulsos de Zoologia 59: e20195931. https://doi.org/10.11606/18070205/2019.59.31

CUEVAS-REYES, P., QUESADA, M., HANSON, P., DIRZO, R. \& OYAMA, K. 2004. Diversity of gall-inducing insects in a Mexican tropical dry forest: the importance of plant species richness, life-forms, host plant age and plant density. Journal of Ecology 92: 707-716. doi:10.1111/j.0022-0477.2004.00896.x

CUEVAS-REYES, P., ESPINOSA-OLVERA, N. A., MALDONADO-LÓPEZ, Y. \& OYAMA. K. 2014. Mexican Gall-Inducing Insects: Importance of Biotic and Abiotic Factors on Species Richness in tropical dry forest. In Neotropical Insect Galls (G. W. Fernandes. \& J. Santos, eds.). Springer, Dordrecht. 
DALBEM, R.V. \& MENDONÇA, M. 2006. Diversity of galling Artropods and Host Plants in a Subtropical Forest of Porto Alegre, Southern Brazil. Neotropical Entomology 35(5): 616- 624.

DETONI, M.L., VASCONCELOS. E.G., RUST, N.M., ISAIAS, R.M.S. \& SOARES, G.L.G. 2011. Seasonal variation of phenolic content in galled and non- galled tissues of Calliandra brevipes Benth (Fabaceae: Mimosoidae). Acta Bot Bras 25: 601-604.

EARTH OBSERVATION SYSTEM LABORATORY, ITCR \& FONAFIFO. 2006. Cober2005crtm05. Atlas CR 2014. [CD]. ITCR, Cartago.

EIGENBRODE, S.D. \& JETTER, R. 2002. Attachment to plant surface waxes by an insect predator. Integr Comp Biol 42: 1091-1099.

ESPÍRITO-SANTO, M. M. \& FERNANDES, G. W. 2007. How Many Species of Gall-Inducing Insects Are There on Earth, and Where Are They? Annals of the Entomological Society of America 100 (2): 95-99. https://doi. org/10.1603/0013-8746(2007)100[95:HMSOGI]2.0.CO;2

FRANKIE, G. W., BAKER, H. G. \& OPLER, P. A. 1974. Comparative phenological studies of trees in tropical wet and dry forests in the lowlands of Costa Rica. Journal of Ecology 62: 881-919.

FLOR, I. C., FLOR, J. C. R. \& FURTADO, P. S. 2018. Insect galls of the Floresta da Cicuta (Volta Redonda, RJ, Brazil). Papéis Avulsos de Zoologia 58: e20185824. https://doi.org/10.11606/1807-0205/2018.58.24

GOETZ, A. P. M., LUZ, F. A., TOMA, TIAGO S. P. \& MENDONÇA JR, M. S. 2018. Gall-inducing insects of deciduous and semideciduous forests in Rio Grande do Sul State, Brazil. Iheringia. Série Zoologia 108: e2018015. https://doi.org/10.1590/1678-4766e2018015

GÓMEZ, L. D. \& KISIMOVA-HOROVITZ, L. 1997. Basidiomycetes. Exobasidiales, Cryptobasidiales. Historic, taxonomic and phytogeographic notes. Revista de Biología Tropical 45(4): 1293-1310.

GUEDES, L.M., AGUILERA, N., FERREIRA, B.G., RIQUELME, S.H., SÁEZCARRILLO, K., BECERRA, J., PÉREZ, C., BUSTOS, E. \& ISAIAS, R.M. 2019. Spatiotemporal variation in phenolic levels in galls of calophyids on Schinus polygama (Anacardiaceae). Journal of Plant Research 132: 509-520.

GÜÇLÜ, S., HAYAT, R., SHORTHOUSE, J.D. \& GÖKSEL, T. 2008. Gallinducing wasp of the genus Diplolepis (Hymenoptera: Cynipidae) on Shrub Roses of Turkey. Proc. Entomol. Soc. Wash. 110(1): 201- 217. https://doi. org/10.4289/0013-8797-110.1.204

HANSON, P.E. \& GÓMEZ-LAURITO, J. 2005. Diversity of Gall-inducing Arthropods of Costa Rica. In Biology, Ecology, and Evolution of Gallinducing Arthropods (A. Raman, C.W. Schaefer \& T. M. Withers, eds.). Science Publishers, Inc, New Hampshire, USA, p. $673-692$.

HANSON P., NISHIDA K. \& GÓMEZ-LAURITO J. 2014. Insect Galls of Costa Rica and Their Parasitoids. In Neotropical Insect Galls (G.W. Fernandes \& J. Santos, eds.). Springer, Dordrecht.

HOLDRIDGE, L. R. \& TOSI, J. A. 1967. The life zone. Life Zone Ecology. San José, Costa Rica: Tropical Science Center.

ISAIAS, R.M.S., CARNEIRO, R.G.S., OLIVEIRA, D.C. \& SANTOS, J.C. 2013. Illustrated and annotated checklist of Brazilian gall morphotypes. Neotrop. Entomol. 42: 230-239. doi: 10.1007/s13744-013-0115-7

LEITCH, I. J. 1994. Induction and development of the bean gall caused by Pontania proxima. In Plant Galls: Organisms, Interactions, Populations. The Systematics Association. (M. Williams, ed.). Clarendom Press, Oxford, London, UK, Special Volume No. 49, p. 283-299.

LEY-LÓPEZ, J., GONZÁLEZ, J. \& HANSON, P. 2019. Plants and gall hosts of the Tirimbina Biological Reserve, Sarapiqui, Costa Rica: Combining field sampling with herbarium records. Revista de Biologia Tropical: 212-227. doi: 10.15517/rbt.v67i2SUPL.37233.

Li, X.Q., Liu, Y.Z., Guo, W.F., Solanki, M.K., Yang, Z.D., Xiang Y., Ma, Z.C. \& Wen, Y.G. 2017. The gall wasp Leptocybe invasa (Hymenoptera: Eulophidae) stimulates different chemical and phytohormone responses in two Eucalyptus varieties that vary in susceptibility to galling. Tree Physiology 37(9): 1208-1217. doi: 10.1093/treephys/tpx098.

LIU, Q., LUO, L. \& ZHENG, L. 2018. Lignins: Biosynthesis and biological functions in plants. International Journal of Molecular Sciences 19(2): 335. https://doi.org/10.3390/ijms19020335

LOBO-SEGURA, J. A. 2019. Diversity of phenological patterns of Handroanthus ochraceus (Bignoniaceae) in Costa Rica. Revista de Biología Tropical 67: 149-158. doi: 10.15517/rbt.v67i2SUPL.37220.
MAIA, V.C. 2001. The gall midges (Diptera, Cecidomyiidae) from three restingas of Rio de Janeiro State, Brazil. Rev. Bras. Zool. 18: 583-629. http://dx.doi. org/10.1590/S0101-81752001000200028

MAIA, V.C. \& OLIVEIRA, J.C. 2010. Galhas de insectos de Reserva Biólogica Estadual da Praia do Sul (Ilha Grande, Angra dos Reis, R.J). Biota Neotropica 10(4): 227-238. http://www.biotaneotropica.org.br/v10n4/en/abstract?invento ry+bn04110042010.

MAIA, V. C., FERNANDES, G. W., MAGALHÃCS, H. \& SANTOS, J. C. 2010a. Two new species of Lopesia Rübsaamen (Diptera, Cecidomyiidae) associated with Mimosa hostiles (Mimosaceae) in Brazil. Revista Brasileira de Entomologia 54(4): 578-583. http://dx.doi.org/10.1590/S0085-56262010000400007.

MAIA, V.C., FLEURY, G., SOARES, G.L.G. \& ISAIAS, R.M.S. 2010b. Description of the female, pupa and gall of Pisphondylia brasiliensis Couri and Maia, 1992 (Diptera: Cecidomyiidae, Schizomyiina) with new records. Braz. J. Biol. 70(4): 1059-1063. doi: 10.1590/S1519-69842010000500021

MAIA, V. \& SOUZA, M. 2013. Insect galls of the xeric vegetation of Ilha do Cabo Frio (Arraial do Cabo, RJ, Brazil). Biota Neotropica 13: 278-288. 10.1590/S1676-06032013000300030.

MAIA, V.C. 2014. Insect Galls of Itamonte (Minas Gerais, Brazil): Characterization and occurrence. Biota Neotropica 14(1): 1-17.http://dx.doi org/10.1590/S1676-06033839

MARTINS, I., PEREIRA, V., SOUZA, E.K., DE PAULA, M. \& CALADO D. C. 2018. Insect galls in three species of Copaifera L. (Leguminosae, Caesalpinioideae) occurring sympatrically in a Cerrado area (Bahia, Brazil). Biota Neotropica 18(1): 1-5. http://dx.doi.org/10.1590/1676-0611-BN-2017-0356

NIEVES-ALDREY, J. L., IBÁÑEZ, A. \& MEDIANERO, E. 2008. Richness and composition of gall-inducing arthropods at Coiba National Park, Panama. Revista de Biología Tropical 56(3): 1269-1286. http://www.scielo.sa.cr/scielo php?script=sci_arttext\&pid=S003477442008000300024\&lng=en\&tlng=en.

MEDIANERO, E., PANIAGUA, M. \& CASTAÑO-MENESES, G. 2010. Comparación temporal de la riqueza y composición de insectos inductores de agallas en el dosel de un bosque tropical. Revista Mexicana de Biodiversidad, 81: 465- 472. https://www.researchgate.net/publication/262634199

MEDIANERO E., BARRIOS H. \& NIEVES-ALDREY L. 2014. Gall-Inducing Insects and Their Associated Parasitoid Assemblages in the Forests of Panama In Neotropical Insect Galls (G. W. Fernandes G. \& Santos J., eds) Springer, Dordrecht.

PASCUAL-ALVARADO E., NIEVES-ALDREY J. L., CASTILLEJOS-LEMUS D. E., CUEVAS-REYES P. \& OYAMAK. 2017. Diversity of galls induced by wasps (Hymenoptera: Cynipidae, Cynipini) associated with oaks (Fagaceae: Quercus) in Mexico. Botanical Sciences 95(3), 461-472. https://doi.org/10.17129/botsci.1215

QGIS.ORG. 2020. QGIS Geographic Information System. Open Source Geospatial Foundation Project. http://qgis.org.

QUIRÓS-ARIAS, L. 2017. Tourism, natural protected areas, conservation, land management, Costa Rica. Revista Geográfica de América Central, 1(158E): 137-183. doi: 10.15359/rgac.58-2.5.

RAMAN, A. 2011. Morphogenesis of insect- induced plant galls: fact and questions. Flora 206: 517-533. http://ac.els- doi.org/10.1016/j. flora.2010.08.004

RETANA-SALAZAR, A.P. \& NISHIDA, K. 2007. First gall-inducing thrips on Elaphoglossum ferns: A new genus and species of thrips, Jersonithrips galligenus from Costa Rica (Insecta, Thysanoptera, Phlaeothripidae). Senckenbergiana Biologica 87: 143-148.

RETANA-SALAZAR, A. P. \& SÁNCHEZ-CHACÓN, E. 2009. Anatomía de la agalla en Ficus benjamina (Moraceae) asociada a "thrips" (Tubulifera: Phlaeothripidae). Revista de Biología Tropical 57 (Suppl. 1): 179-186. http://www.scielo.sa.cr/scielo.php?script=sci_arttext\&pid=S0034774420 09000500016\&lng $=$ en\&tlng $=$ en.

RIBEIRO, A., BALBI, M. I. \& URSO-GUIMARÃES, M. V. 2019 Characterization of insect galls from a vegetation area in Altinópolis, São Paulo State, Brazil. Papéis Avulsos de Zoologia, 59: e20195904. https://doi. org/10.11606/1807-0205/2019.59.04

RONQUIST, F. \& LILJEBLAD, J. 2001. Evolution of gall wasp-host plant association. Evolution 55(12): 2501- 2522.

ROHFRITSCH, O. \& SHORTHOUSE, J. D. 1982. Insect Galls. In Molecular Biology of Plant Tumors (G. Kahl G. \& J. S. Schell, eds.). Academic Press, New York, p. 131-152. 
SAITO, V. S. \& URSO-GUIMARÃES, M. V. 2012. Characterization of galls, insect galls and associated fauna of Ecological Station of Jataí (Luiz Antônio, SP). Biota Neotropica, 12(3): 99-107. https://dx.doi.org/10.1590/S167606032012000300011

SANO, M., HAVILL, N.P. \& OZAKI, K. 2011. Taxonomic identity of a galling adelgid (Hemiptera: Adelgidae) from three spruce species in Central Japan. Entomological Science 14: 94- 99. doi: https://doi.org/10.1111

SANTOS, J.C., ALMEIDA-CORTEZ, J.S. \& FERNANDES, G.W. 2011a. Diversity of gall-inducing insects in the high altitude wetland forests in Pernambuco, Northeastern Brazil. Braz. J. Biol. 71: 47-56. http://dx.doi. org/10.1590/S1519-69842011000100008

SANTOS, J. C., ALMEIDA-CORTEZ, J. S. \& FERNANDES, G. W. 2011b. Richness of gall-inducing insects in the tropical dry forest (caatinga) of Pernambuco. Revista Brasileira de Entomologia 55(1): 45-54. https://dx.doi. org/10.1590/S0085-56262011000100009

SILVA, E. C., SANTOS, B. B. \& ARAÚJO, W. S. 2018. Insect gall occurrence in savanna and forest remnant sites of Hidrolândia, GO, Brazil Central. Papéis Avulsos de Zoologia, 58: e20185804. https://doi.org/10.11606/18070205/2018.58.04

Sistema Nacional De Áreas De Conservación (SINAC). 1998. AConservacionSINAC2014. Atlas CR 2014. [CD]. ITCR, Cartago.

Sistema Nacional De Áreas De Conservación SINAC. 1999. Areassilvestresprotegidas2014crtm05. Atlas CR 2014. [CD]. ITCR, Cartago.

Sistema Nacional De Áreas De Conservación (SINAC). 2014. Parque Nacional de Santa Rosa [Santa Rosa National Park]. Retrieved from http://www.sinac. go.cr/ES/ac/acg/pnsr/Paginas/default.aspx

SHORTHOUSE, J. D. \& ROHFRITSCH, O. 1992. Biology of the Insect-Induced Galls. Oxford University Press, New York, USA, p. 157-169.

SOTO-MONTOYA, C. 2007. Rios150000crtm05. Atlas CR 2014. [CD]. ITCR, Cartago.
STONE, G. \& SCHÖNROGGE, K. 2003. The adaptive significance of insect gall morphology. Trends in Ecology and Evolution 18: 512-522. doi: 10.1016/ S0169-5347(03)00247-7

TOOKER, J.F., ROHR, J. R., ABRAHAMSON, W. G. \& DE MORAES, C. M. 2008. Gall insects can avoid and alter indirect plant defenses. New Phytologist 178: 657- 671. doi: 10.1111/j.1469-8137.2008.02392.x

URSO-GUIMARÃES, M.V., SCARELLI-SANTOS, C. \& BONIFÁCIO-SILVA A, C. 2003. Occurrrence and characterization of entomogen galls in plants from natural vegetation areas in Delfinópolis, MG, Brazil. Braz. J. Biol. 63: 705-715. http://dx.doi.org/10.1590/S1519-69842003000400018

URSO-GUIMARÃES, M.V. \& SCARELLI-SANTOS, C. 2006. Galls and gall makers in plants from the Pe-Gigante Cerrado Reserve, Santa Rita do Passa Quatro, SP, Brazil. Braz. J. Biol. 66: 357-369. http://dx.doi. org/10.1590/ S1519-69842006000200018

URSO-GUimarÃES, M. V., CASTEllo, A. C. D., KATAOKA, E. Y. \& KOCH, I. 2017. Characterization of entomogen galls from Mato Grosso do Sul, Brazil. Revista Brasileira de Entomologia 61(1): 25-42. https://doi. org/10.1016/j.rbe.2016.08.002

VIEIRA, L. G., NOGUEIRA, R. M., COSTA, E. C., CARVALHOFERNANDES, S. P. \& SILVA, J. S. 2018. Insect galls in Rupestrian field and Cerrado stricto sensu vegetation in Caetité, Bahia, Brazil. Biota Neotropica 18(2): e20170402. https://doi.org/10.1590/1676-0611-bn-2017-0402

WILLIAMS, M. 1994. Plant galls: a perpective. In Plant Galls: Organisms, Interactions, Populations. The Systematics Association (M. Williams, ed.). By Clarendom Press, Oxford, London, UK, Special Volume No. 49, p. 283-299.

XIAO, K., MAO, X., LIN, Y., XU, H., ZHU, Y., CAI, Q., XIE, H. \& ZHANG, J. 2017. Trichome, a functional diversity phenotype in plant. Mol. Biol. 6: 183. doi:10.4172/2168-9547.1000183.

Received: 06/11/2020

Revised: 26/04/2021

Accepted: $31 / 05 / 2021$

Published online: 19/07/2021 